U. S. COMMISSION OF FISH AND FISHERIES, GEORGE M. BOWERS, Commissioner.

\title{
335
}

S8

opy 1

\section{AQUATIC PRODUCTS IN ARTS AND INDUSTRIES.}

\author{
FISH OHS, FATS, AND WAXES. \\ FERTILIZERS FROM AQUATIC PRODUCTS.
}

BY

CHARLES H. STFVENSON.

Extracted from U, S. Fish Commission Report for 1902. Pages 177 to 279. Plates 10 to 25 .

WASHINGTON:

GOVERNMENT PRINTING OEFICE.

1903 . 



\title{
SH 335
}

\section{.58}

Copy 1

S. COMMISSION OF FISH AND FISHERIES, GEORGE M. BOWERS, Commissioner.

\section{AQQUATIC PRODUCTS IN ARTS AND INDUSTRIES.}

\author{
FISH OILS, FATS, AND WAXES.
}

FERTILIZERS FROM ÄQUATIC PRODUCTS.

CHARLES H. STEVENSON.

Extracted from U, S. Fish Commission Report for 1902، Pages 177 to 279. Plates 10 to 25 .

$\rightarrow$

WASHINGTON :

GOVERNMENT PRINTING OFFICE,

1903. 


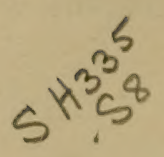

D. OF D
MAR $5 \quad 1908$ 


\section{AQUATIC PRODUCTS IN ARTS AND INDUSTRIES.}

FISH OILS, FATS, AND WAXES. FERTILIZERS FROM AQUATIC PRODUCTS.

BY CHARLFiS H. STHVHNSON,

F. C. $1902-12$ 


\section{'TABLE OF CONTENTS.}

FISH OIMS, FATS, AND WAXES.

\section{General review}

The whale oils:

Brief review of whaling industries...

The blubber and its yield of oil.... Conversion of the blubber into oil.... Refining sperm oil and whale oil.

Porpoise and black-fish oils

Oils from seals, walrus, etc:

Seal oils ............ . . . . 209

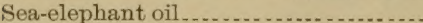

Walrus oil

Oil from sea-lions and fur-seals

Oils from livers of cod and related species:

Sources of supply

Deseription of livers and resulting oils

Preparation of medicinal oil

Production of currier's' oil

Oils from the livers of sharks and related species
FISH OILS, FATS, AND WAXES-continued.

Page.

Menhaden oil .......................... 292

Herring oil . . .

Oil from waste fish ...................... 239

Oil from fish heads .................. 240

Oil from viscera of fish .................. 241

Miscellaneous oils......................... 242

Spermaceti refining and manufacture _... 214

Ambergris .............................

FERTILIZERS.

General review

The menhaden industry:

History and extent of the industry ... $\quad 256$

Cooking and pressing the fish........ 259

Treatment of the scrap .............. 265

Fertilizers from fish waste or refuse.... $\quad 269$

Fertilizer's from crustaceans............. 273

Agricultural lime from mollusk shells _.. $\quad 274$

Seaweeds as fertilizer's .................... 275 



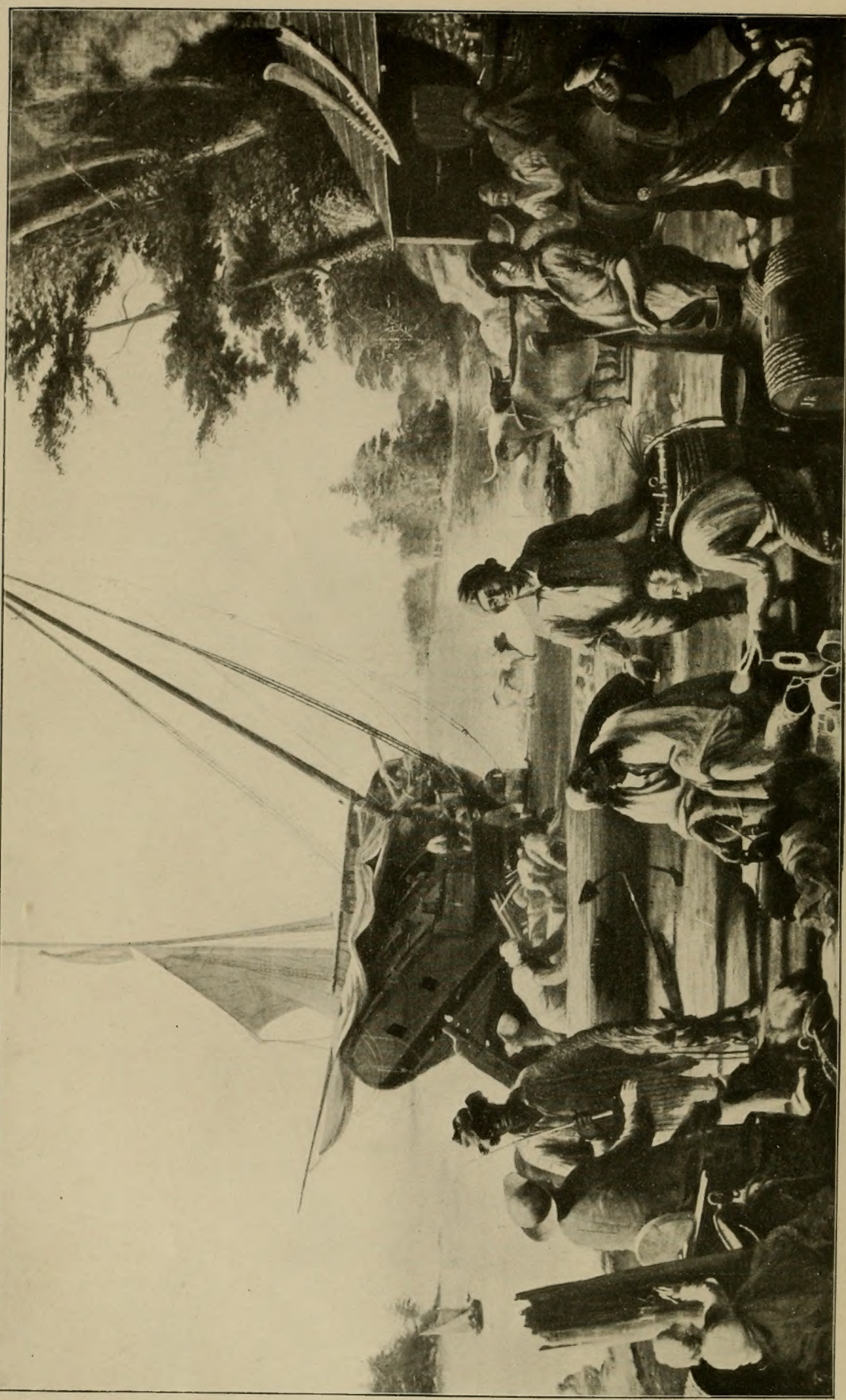

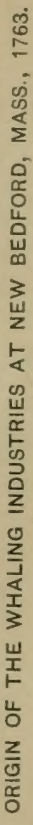




\section{AQUATIC PRODUCTS IN ARTS AND INDUSTRIES.}

By Charles H. Stevenson,

PREFATORY NOTE.

The diversity and magnitude of the industries based on the utilization and manufacture of aquatic products are not fully appreciated. In a previous publication of this Commission ${ }^{a}$ the great variety of fishery products used for food and their methods of preparation were discussed. In addition to the numerous items of food articles, the materials employed in the arts and industries compare favorably in variety and interest with similar products of the land. These may be roughly separated into five classes, viz, (1) oils, fats, and waxes; (2) fertilizers from aquatic products; (3) skins of aquatic animals and their products of furs and leathers; (4) the hard substances, as shells, scales, bones, ivories, etc., and (5) miscellaneous articles not properly classed with any of the foregoing, as glue, isinglass, seaweeds, sponges, marine salt, etc. The total value of the annual product of these throughout the world roughly approximates $\$ 45,000,000$ in the condition in which they are first placed on the market, of which the United States contributes $\$ 11,000,000$.

Some of the most extensive fisheries of the world have been proseeuted almost wholly for the purpose of supplying the oil markets. Whale oils were the first of all oils-animal or mineral-to achieve commercial importance, and for fully a century the whale fishery ranked as one of the principal industries of America. Indeed it was of far greater relative value in the industrial wealth of the country than the petroleum industries are at the present time. The seal fisheries of Newfoundland, Norway, and other northern countries, which rank among the most daring and venturesome of marine enterprises, are dependent for their prosperity on the oil obtained from the thick blubber underlying the skins of the animals. The taking of menhaden on the Atlantic coast of the United States for conversion into oil and fertilizer gives employment to thousands of men and to several million dollars of capital. And in the various cod fisheries of the world the rendering of the livers into oil for medicinal as well as for technical uses is a source of great profit. In addition to these extensive industries there are numerous minor fisheries supported entirely, or to a large extent, by the oil markets. 
From all varieties of aquatic oils may be separated, at a low temperature, a solid fat or grease known as "foots" or "stearin," somewhat similar to the tallow obtained from sheep and oxen. This is obtained in the process of refining the oils, and the yield ranges from 3 to 20 per cent of the bulk of the crude oil. It is sold at a few cents per pound, and is used as a substitute for tallow from sheep and oxen in sizing yarns, as emollient in leather-dressing, and for various other technical purposes.

Bleaching the various marine oils produces a semi-solid fat known as "sperm soap," "whale soap," "menhaden soap," etc., according to the variety of oil treated. This material is used in smearing sheep, washing fruit trees, soap-manufacture, etc.

In the process of refining sperm oil, instead of the foots, the waxlike spermaceti is obtained, the quantity yielded approximating 11 per cent in weight of the crude sperm oil. Spermaceti is used principally in candle-making, as an ointment for medicinal purposes, for producing a polish on linen in laundering, and for self-lubricating cartridges.

Another wax-like substance peculiar to the sperm whale is ambergris, an extremely valuable substance found at rare intervals, but sometimes in comparatively large quantities within the intestines of that animal, and also afloat on the sea or cast up on the shores. A single whale has yielded $\$ 50,000$ worth of this material, and several intances are reported in which $\$ 20,000$ worth has been obtained from one cetacean. Ambergris was formerly used as an incense, in cookery, as a medicine, and as a perfume. Its principal use at present is in the preparation of fine perfumes.

The principal aquatic products used for fertilizer are seaweeds, shells of mollusks and crustaceans, non-edible species of fish, especially the menhaden, and waste parts of edible species. At present the quantity of this fertilizer produced annually in the United States alone approximates 420,000 tons, worth $\$ 2,120,000$. This is capable of very great increase, especially in the quantity of seaweeds and waste fish employed.

Doubtless 50 per cent of the world's stock of furs is obtained from aquatic animals. Formerly this percentage was greater, but it is reduced by the decrease in product of beaver, fur-seal, otter, and seaotter, and the large increase in quantity of certain land fur-bearers. Fully 75 per cent of all the furs produced in the United States are yielded by aquatic animals, principally the fur-seal, mink, muskrat, beaver, otter, and sea-otter. The value of the annual output of these in the United States approximates $\$ 2,500,000$ in the raw or undressed state.

Leather is made from the skins of practically all the aquatic mammals and of most of the species of fish, but these usually rank among novelty or fancy leathers. Seal leather is produced in large quantities, the value of the annual product averaging $\$ 1,500,000$. 
The hide of the beluga, or white whale, is one of the best of allskins for leather purposes, on account of its durability, strength, ancl pliability. It is sold as porpoise leather, and probaldy $\$ 200,000$ worth of tammen hides are marketed annually. Allimator skins are also oltained in large quantities, and owing to the peenliarity of their markings, are used entirely as fancy leather. Tanned walrus hides, especially the thick ones, are in great demand for polishing-wheels and other mechanical purposes, and ahout $\$ 100,000$ worth are sold annually. Among the aquatic skins used to a less extent for leather purposes may be mentioned sea-lion, porpoise, sea-elephant, and a very large variety of fish skins, especially those of sharks.

Of the hard substances existing in the form of shells, bones, scales, etc., shells are hy far the most important. Nearly, if not quite, $1,000,000$ tons are secured annually in the Linited States, consisting principally of the shells of oysters, clams, river mussels, and a very much smaller quantity of other varieties. I fair valuation of these at the places of consumption would doubtless amount to $\$ 1,500,000$; to this should he added about $\$ 600,000$ as the value of pearls secured during the last year in the Mississippi Valley and elsewhere. The value of the shells secured outside of the Cniter States, principally mother-()f-pearl shells, amounts to $\$ 5,(100), 000)$ or $\$(6,000,000$ annually, and the pearls secured sell for nearly an cqual amount. Pearls are not olotainerl in the seas in such large cuantities as formerly, hut their value is ereatly increased. The manufacture of mother-of-pearl and sweet-water shell in the form of buttons, buckles, knife-handles, pistol-stocks, cte., gives employment to nearly 10,000 persons in this rountry and to probably three times that number in Europes and elsewhere.

The yield of whalebone in the Uniterl States fisheries is less than 5 per cent as much as it was 50 years ago, but the reducerl yield has been largely counterbalanced by the increase in value per pound. The product in the American fisheries now approximates 120,000 pounds each year, worth $\$ 500,(000)$, and about $\$ 150,000$ worth is obtainerl in all other parts of the world. At the present market price the total value of whalehone secured in the Uniterl States fisheries since 1850 is not far from $\$ 200,000,000$.

(omparatively little tortoise shell is producer in this country, the amual yield approximating $\$ 12,000$ in value. The West Indies, south America, Afriea, East Inclies, Pacifie islancls, ete., supply probahly $\$ 500,000$ worth each year, much of which is manufactured in the United States.

Iittle economic use is made of fish scales, exerpt in the production of artificial pearls and other ormamental ol,jects. Unique and at raletive artificial flowers are mate from the scales of sheepshead, tarpon, drum-fish, channel bass, ete.

Cuttlebone and roral are not produecer in the United states, but large quantities are imported into this country. 


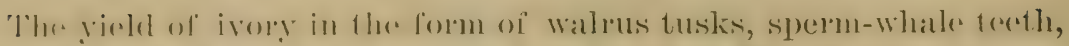

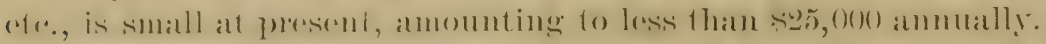

'The principal infustrial use for bones of aquatice animals is for (o) for omamentation, hut their agerereate value is inconsideralole.

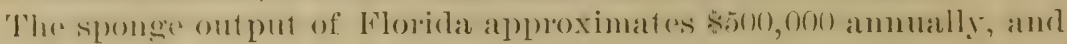
the value of the probluet throughout the worle is probahly not fat from \$5, 000,000 .

The uses of seatweres ate numerous. Thery furmish thousands of tons of forlitizer, many nutritious fooks, and a variety of rhemirals, esperally iofline and bromine. ()there uses are in sizing falmies, as a monelant in clyeing, in refining becr, in making paper, fishing lines, ropes, for stuffing upholstory, patring poreelain, etc. The Jatpancese have been especially adept in discovering uses for seaweeds.

Glue-manufacture povides an outloti for the profitilhle use of much waste in dressing dlexel codfish. This material was formerly discarded as useless, but now tens of thousands dollars' worth of choicestinge for postage stamps, court-plaster, ablhesive papere, lathels, envelopes, for merhanical purposes, and for sizing of straw geosh

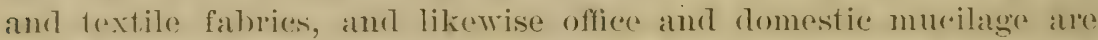
manufatotured from fish skins. The product is rerge mudeh stronger and more durable than glue mado from the skins of mammals.

Isinglass mate from the somols on swimming blatelers of sturgenen, hakr, corl, squeteagure, ofr., is used for clarifying fremented lifuors, the cellular construction forming a sort of net which carries down floating patricles. IIowerer, the use of this material has been much reducerl, owing to the numerous substitutes obtained from domestic animals.

Commercial allumen may be mate from the eggs of cod and other species, but it has not yet been extensively manufactured.

The preparation of oils and fertilizers, to which the present report is alevelel, is intimately associated, especially in the case of the menhadron industry. The tissues remaining after' the extraction of oil from herring and other waste fish, from the blubber of seals, porpoise, and the like, from the livers of cood and relaterl species, the livers of sharlis, from the waste parts of fish in dressing, ete. are commonly prepared for fertilizing purposes, and the preparation of the two materials is ustally carried on in the same factory ant in some instances by the same workmen. Fon this reason it appeal's desirathe to combine in one patper the areount of the preparation of oils and fertilizers from anuat ie products. 'This paper', however, is divided into two parts, one relating to the preparation, characteristics, and uses of fish oils, fats, and waxes, and the other to the utilization of aquatic products as fertilizer's. 


\section{FISH OILS, FATS, AND IVAXES.}

\section{GENERAL REVIEW.}

Previous to 1600 there was comparatively little demand for oil of any kinct. Tallow dips, pine knots, and the like afforded the principal means of illumination. The quantity of machinery in use was small and lubricants were in little demand. The leather industries were undereloped and the greases recuired in eurrying were obtained principally from the fat of the animal furnishing the skin, supplementer later by certain vegetable oils.

The value of whale oils for purposes of illumination was not unknown previous to the seventeenth century, but the fishermen were unequal to the task of capturing the "etareans, in large numbers. I few that drifted ashore were secured, the use of the oil for illuminating purposes developed; and, as the experience and daring of the fishermen increased, their wanderings extender not only offshore, but to distant seas. After the invention of the Argand burner in 178t, whale oil became the principal illuminating agent, and at the beginning of the nineteenth century it was in general use. Not only were resirlences lighted with it, hut also streets and municipal buildings. A largo fuantity of sperm oil was used in residenees of the wealthy and also in lighthonses, that bring the prineipal illuminant in the coastal lights of the Tnited states, England, Scotland, Ireland, France, and other advanced countries up to 18:3:. The currying trade had in the meantime increased in importance, and grease for softening was secured in the form of oil from seal, walrus, sea-elephant, cod livers, ete. The increasing use of machinery resulted in an enhanced demand for a lubricant, which was generally furnished in the form of sperm oil. This resulterl in very high prices; sperm oil, for instance, ranged from $\$ 1$ to $\$ 2$ per gallon, although the fishery increased until it was one of the most important organized industries of the world. Other fish oils became important commercial products, including vils from the livers of cod, hatdock, sharks, ete, from herring, menhaden, sardine, pilchard, and other species of the Clupeidce family, and a miscellaneous variety of minor importance.

The continued upward tendency in prices, as a result of an increased demand, led to endeavors to find substitutes. Lard oil was successfully introduced as a summer lubricant in the place of sperm oil for ordinary uses. Colza or rape-seed oil likewise entered into competition with it as an illuminant, and the process of refining was improved until it hecame a fairly satisfactory substitute at about half the price. In 18:32 France alopted colza in place of sperm oil as a light-house illuminant, and in $18 \pm 5$ it was adopted in the light-houses and light- 
ships of (ireat Britain. The diffientty of obtaining rape-seerl oil in the Tnited states and the importane of the whaling industry to the national wrelfare catused the vise of sperm oil in this country for ten reats longere, when throrgh the researches and experiments of Pro-

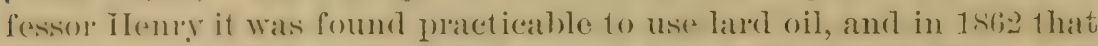
berame the illuminant in the light-houses of the Lnited states. A few years later both colza and lard oils were superseded by forms of petroleum.

Not only dicl the products of petroleum take the place of arpuaticanimal oils ats illuminants, but they seriously interfered with them in the markets as lubricants. Then eame the development of renctering and refining a large number of regetalble oils, which are now used for many purposes formerly served hy fish oils. Among these vegetalsh products are olive oil, cotton-seed sil, linseed oil, and, to a less extent, palm oil, cocoanut oil, corn oil, ete. The employment of these substances and a large decrease in the ahundance of whales have resulted in at great reduction in the extent of the whale fishery, the fleet decreasing from 735 ressels in 1840 to 35 in 1962.0 . Those marine (nterprises more or less associated with the whald fisheries, as the taking of seals, sea-elephants, walrus, etc., havedecreased correspondingly.

Fish oils have therefore, to a large extent, given place to land products, and their diminished sale and reducerl price have greatly decreaserl the prosperity of many fisheries. At present the use of fish oils for illumination as compared with that of mineral oils is very small in those countries where the latter are obtainable, their principal use being in miner's' lamps. But among many semicivilized people, especially those of subpolar regions, marine-animal oils are more easily obtained than petroleum, so that the native products continue in use. Anci notwithstanding the large amount of mineral oils now used for lubrication of heary machinery, there is yet an extensive demand for fish oils for that purpose, experience having showi that by theirjudicious blending with hydrocarbon oils a greater uniformity of lubrication is secured, and that less quantity is required than by use of mineral oil alone. The outlook for an increased use of fish oils in leather-dressing is said to be not encouraging, owing to a decrease in "hamel-stuffing" and the increasing popularity of chrome tamnage, in which only a small quantity of oil is recpuired, and that usually a superior cuality of neatsfoot. There is a wide field of technical uses wherein cortain fish oils ean not readily be dispensed with, espercially for lubricating delicate machinery, in stecl-tempering and screwcutting, as a body for paints to be applied to out-of-door surfaces, in the textile tractes where only saponifiable oil can be satisfactorily employed, etc.

In addition to their many technical uses, marine-animal oils are also used for nourishment to a considerahle extent. The Eskimos and other primitive people depent very latrely on the blubber of 
seals, walpus, anrl whales, for fool supplies. Among moro avilized

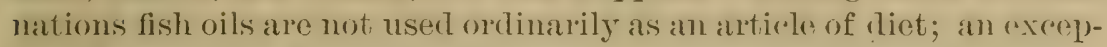
fiom, howevere, is the well-known and valuahle cort-liver oil, of which 1 wenty or thirty thousand barrels are ammally consumed in cases of malnutrition. Certain therapeutic qualities are also attributed to various minor oils, as those from the shark, (ulachon, manatee, clugong, alligator, terrapin, etc., but the use of these is not general.

The marine-animal oils are tivisible into four principal groups, viz: (1) blubber oils; (z) head oils; (:) liver oils, and ( $( \pm)$ body oils. The blubber oils are obtained from the layer of fat between the shin and the flesh or muscular tissues of whales, seals, walrus, sea-lion, porpoise, hlack-fish, etc. Ifear oils are securer from cavities in the skull and from other heal parts of sperm whales, black-fish, porpoise, sworl-fish, halibut, ete. Some of these are of superior quality, as those of the black-fish and porpoise, for instance, which sell for sit to $\$ 10$ per gallon. The head oil of the sperm whale yields the valuable spermaceti. Those of the third group are obtained principally from the livers of corl and to a less extent from hatdock, hake, pollock, ensk, ling, sharks, and skates. The bodies, heats, and riscera of these fish are so slightly oleaginous that they are rarely utilized economically for oil purposes. The body oils, or fish oils, "as they are now generally known commercially, are obtained principally from species of the hrring family-the menhaten in America, the herring, sarthine, and pilchard in Europe, and the iwashi in .Japan. In case these fish are user for food in large quantities, the visceral are generally devoted to oil-rendering. Most of the other species of food-fish confain so little oil that it is profitable to use only the intestines or of her refuse dressings for this purpose. And in some the yield of oil is so small that not even the waste parts can be profitably utilized in this mamner. In addition to the foregoing, there are a number of oils produced in various localities which enter largely into the domestic economy of those procuring them and yet are of little commercial importance, as alligator oil, turtle oil, terrapin oil, etc.

The total amnual product of rerucle oil from marine animals throughout the world is estimated at $18,300,000$ gallons, of which $5,5(1),(000$ represents the prorluet from the hlubber and fat of whales, seals, and the like; $5,300,000$ gallons is from the livers of cod, shark, etc., and 7,500,(00) gallons from menhaden, herring, sardinc, and other species, including waste in dressing fish.

Even a hrief survey of the fish-oil inclustries reveals the fact that they are not by any means so extensiva as the natural resources permit. True, the right-whale fishery is prosecuted apparently to an

"The term "fish oil" is used by chemists and other technologists as comprising oils from all aquatic animals. Previous to 180 it generally refer ed to whale oils. At the present time its commercial use is generally confined to oils obtained from fish alone. In a restricted sense it refers especially to oil obtainer from the principal species of the herring family in the locality in which the term is applied. Thus "fish oil" on the Atlantic coast of the United States ind. "ates in a restrieted c:mmmer(ial s'mse the oil of the menhaden; in Norway, the herring; in France, the sardine; in Japan, the iwashi, etc. 
extreme limit, and 1 ho same is possibly true of the seat fisheries of

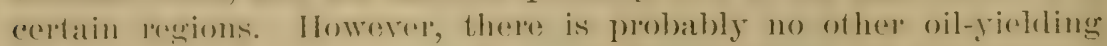

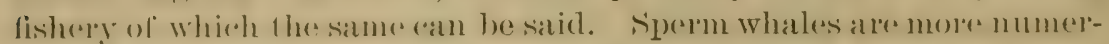
ous than they Wore lifty yoars ano, when the L nited states empleyert 300 ressels in their catpture, socuring 100,000$)$ batrels of oil ammually,

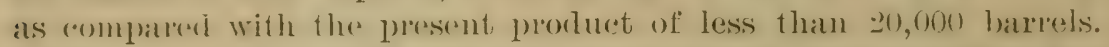

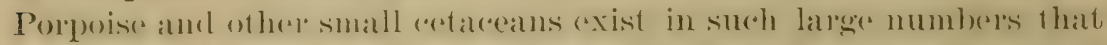
humblexls of thousants if not millions of gallons of oil can he secoured from them. ()nly a very small pereentago of the oil-yielding sharks

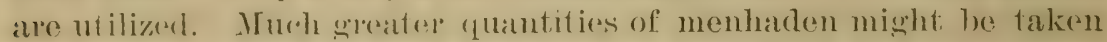

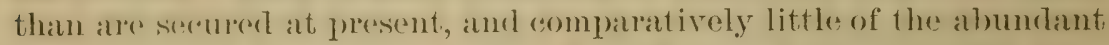
waste lish and dressings or refuse from the markets, "anneries, efe., aro used in oil-production.

The principal reason for this is that the present esomomice anditions do not. warlant an extension of these industries. 'Tho market for fish oils is regulated by that of the mineral and regedable prortucts which are used as substitutes, and which ean he sold al very low priecs, making it necessary to rxereise very great eromomy in the proluction of fish oils. Tressels, fartories, ete., already on hamel may be used, but in the United states at loast it is questionalole whether the huileling of new and costly requipment for oil-production womlet prove profitable moler present market conditions oxcept in sperially favorable instances, unless the colosest reonomy be plateticert. The vessols composing tho present sperm-rwaling fleet, for instancer, may be kepti employed with a fair profit, but with the presint pricess the fitting out of expensive new ressels can scarcely meet with a large return on capital invested. The present equipment of menharlen steamers and factories was built and paid for during a period of prospexity, when menhaden wil was high in price, and they mat be continued in service with profit, but the conditions are not 'nonu'aging for a weat extension of the industry. If a profitable market could be foumd for the product, the yield of fish oils throughout the worlel coulel probably he increased many times its present extent.

THE WHALE OILS.

\section{BRIEF REVIEW OF THE WHALING INDUSTRIES.}

It is searecely within the province of the present report to enter into a detailed history of the whale fisheries, muquestionably the most pietumescue and once the most (xtensive of all marine industries of the worlel. In orler, however, to present a fair idea of the protuction and ufilization of whale oils, it is desirable to review briefly the history and present conditions of these industries.

Whales ar divisible into two groups, (1) toothed whales and (2) bone-bearing or whalebone whales. 'To the first group belongs the sperm whale or rachalot, which yielels sperm oil, spermaceti, ivory, and ambergris. This group also includes the bottle-nose whale, the 


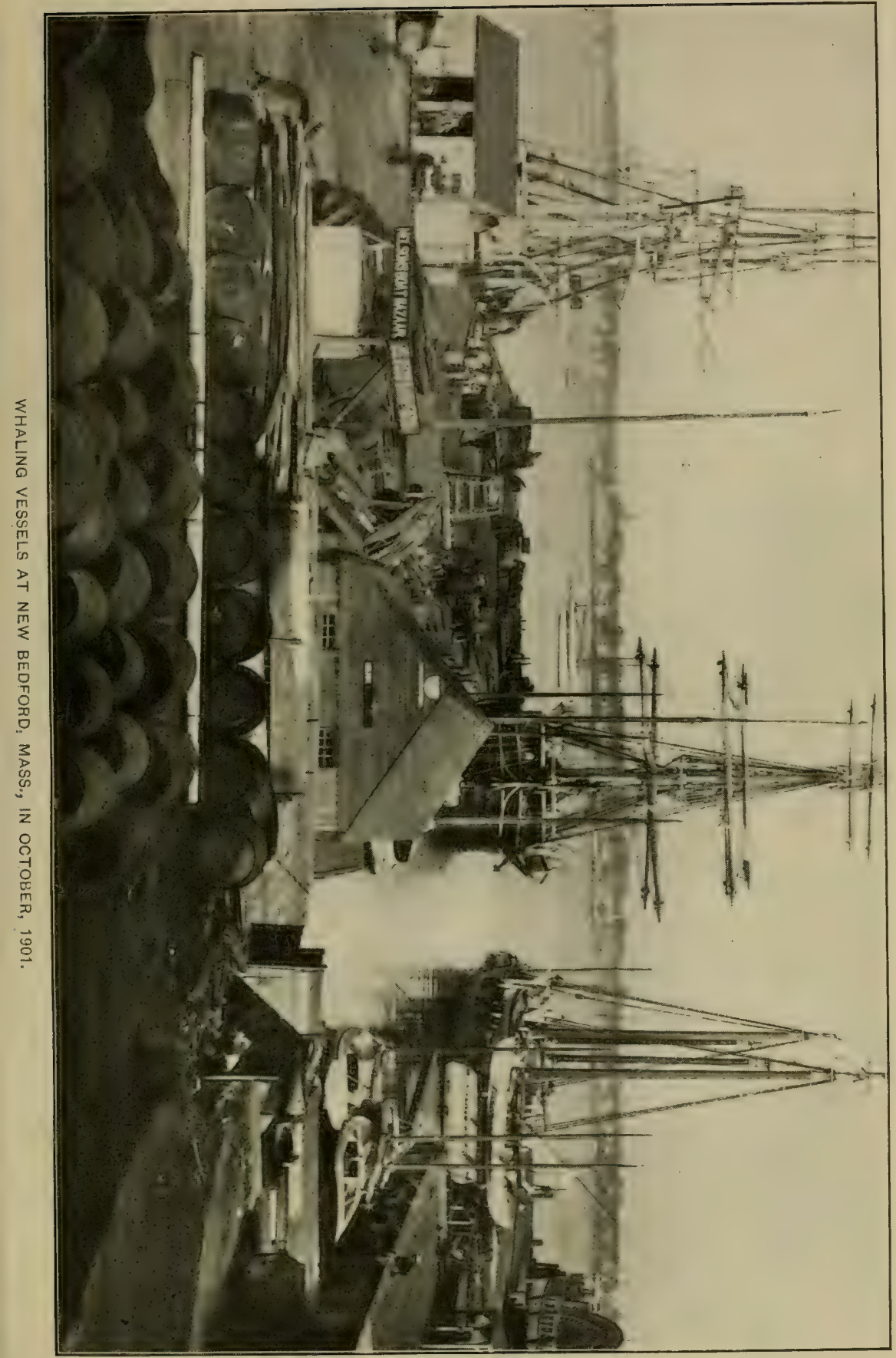



pilot whale, the behga or white whale, and many speries which ane not. popularly known as whales, including the narwhal, grampus, orea or kille:, rolphins, porpoises, ctre. The bone-hearing whales are tivisible into two clisses, (1) smooth whales and (l) furowed whales, or rorcuals. The first embraces the right whales of different species and the bowhead or Arctic whale, all of which are prized for their oil and baleen. Of the rorquals, or those whales possessing longitudinal folds of blubber on throat and stomach, may be mentioned the humpback, finback, sulphur-bottom, and Califormia gray whale. As these are ortinarily difficult of capture and are of minor.value, the whalebone being rather short for commercial use, they have not been pursued so extensively as have the sperm, right, and bowhead whales. In the I'nited states markets the stanklarl varieties of oils are "sper"m oil" and "whate oil," and sometimes "humpback oil." "Whale oil" is a mixture of the product of all whales except the sperm whate, and sometimes includes that of black-fish and walrus.

The use of whale oil appears to be of ancient origin. Doubtless it was first obtained from whales accidentally stranded on the shores, a more frequent occurrence during the early abundance of the cetaceans than at present, when their numbers have hern so greatly rochuced by excessive fisheries. As the demand for the oil increased beyond the supply available from stranded whales, individuals sighted from the shore were attacked and beached. Owing to the frailty of the hoats and equipment, this was a more daring attempt than might be supposerl. It is difficult to trace the origin of the fishery, but certainly it was prosecuted a thousand years ago.

Just prior to the Revolutionary war, according to starbuck and other anthorities, there were 183 American ressels in the right-whale fishery of the North Atlantic waters, and 125 were engager in eruising for sperm whales from Newfoundland to the coast of IBrazil. The Revolutionary war and the war of 1812 interfered with the fisheries; but during the period of peace following 181 they increased greatly in extent until 1st6, when the fleet numbered 6rs ships and barks, :35 hrigs, and 22 schooners, a total of 735 ressels, with an aggregate tonnage of $2: 3: 3,1 \times !)$ tons, and a value of $\$ 21,075,000$, exclusive of outfits and supplies. The entire capital invested in the fishery and its associated industries at that time apporoximated $\$ 40,000,000$, and 40,000 persons derived from it their chief support. During the same year the whaling fleet of all Europe numbered but :30 ressels. The crude value of the American eatch from 1840 to 1860 areraged about $\$ 8,000,000$ ammually. The greatest value was in 1s5.t, when 2,:315,924 gallons of sperm oil worth $\$ 1.48 \frac{3}{4}$ per gallon, $10,07 \pm, \$ 66$ gallons of whale oil worth 592 cents per gallon, and $3,4+5,200$ pounds of whalebone worth 391 . cents per pound were secured, the total value being $\$ 10,802,504$. In the preceding year, 185:3, the total protluct was $3,246,925$ gallons of sperm oil, 8,19:3, כ91 gallons of whale oil, and $5,652,300$ pounds of whalebone, the whole valued at $\$ 10,766 j, 521$. 
Finerm oil and whale oil then served notrly all the diversified nses

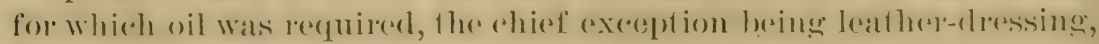

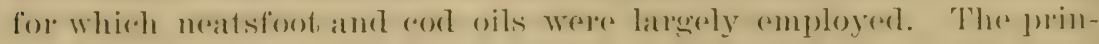
(.iphal uses were as illuminant, lubricalor, in colelage-mamulateture, screw-entting: and sterel-tempering. The streets of the principal reities "rese lighted with the oil, and theaters and public buildings were lighterl with gas marle from the foots. A stock anerotote at the time referred to foreign sailor's climbing up the posts of the New Tork stroet lamps to drink the whale oil, thus leaving the city in tarkness.

'The extent of the fisheries soon began to tell on the abundance of the whales, necessitating much longer and more costly voyages, and consepuently higher prices for the produrts. With the increased price came the active search for substitutes, and colzat oil and lard oil were laresely employed. The competition, however, hat little effect on the market, for whale products until the atoption of petroleum as an illuminant, and subsequently as a lubricant. Its dangerous qualifies at first graatly checked its use, but as improved methorls of refining were introfuced it was fuite generally adopted and proved most influential in decreasing the profits of the whale fishery.

The restricted market and the reduced jorice resulted in a warlual decrease of the whale fishery. Various agencies acceleraterl this decrease, while others retarted it. Among the former may br mentioned the destructive influences of the civil wat, including the sinking of :3i ressels in blockating Charleston ITarbor, and the huming: of 46 vessels, with outfit, supplies, and cargoes hy privateers; also the luss of :3:) ships in the ice of the Aretic Ocean in 1871, ant a similar abandomment of 12 ressels in 1876 . Among the agencies tending to retard the decrease in the fishery is the greatly enhanced ralue of whalebone, which increased from 13 cents per pound in 1s.3:3 to st per pound in 1s:1. Indeed it is the whalebone market alone which sus. tains the present right-whale fisheries of the world. The table on page $2(1)$, showing the annul product of sperm oil and whale oil from 1560 to 1902, inclusive, presents a fair idea of tho gratual redurtion in extent of the American whale fisheries. Owing to the dexpatsed extent of the fishery, sperm whales are increasing in numbers and are apparently more abmolant at present than at any time since the fifties. The bowhead and right whales, howevere, are doubtless more scaree tham at any time since their capture became an object of commercial pursuit.

In 1!)1, the 20 sperm-whalers cruising in the Atlantic Ocean met. with goor success, especially those on the IIatteras and Charleston grounds, securing 12,50) bitrels of oil, according to the Whrlemen's Shipping List, an average of 627 barrels to each ressel. Tho same season in the Aretic and North Pacific, however, was the poorest for many years. 'The fleet there consisted of 11 steamers and 6 barlis. 'Three steames's were lost, and the total aateh was only $4: 3$ howheads and 1:) right whales, as rompared with so bowheals and 14 right. 
whales in 1900. The yield of oil approximated 2,870 latrels, and of whalebone 105,150 pounds. Five barks were employed in spermwhaling of the coast of Japan, taking 4,100 barrels of oil. The market for sperm oil in 1901 opened at 55 cents per gallon, but gradually increased and closed the year at about lis cents per gallon. The price of whale oil at san Francisco was 32 to 38 cents and in the Eastern markets 38 cents per gallon.

In 1902 the whaling fleet of the Tnited states consisted of 8 steamers, 18 barks and brigs, and 12 sehooners, aggregating 8,366 tons. Of these, 11 batks and 10 schooners were sperm-whale fishing in the Atlantice ()cean, \& steamer's in the Aretic, 6 barks in ()khotsk Sea and oft the coast of Japan, 2 schooner's in IIudson Iay, and 1 brigr at Desolation Island.

The total whale-oil product of the world at present approximates $3,000,000$ gallons yearly; of which 750,000 gallons are produced hy the United states fisheries, 900,000 by those of Norway, and the remainder by scotland, Russia, Japan, Newfomndland, and other countries.

\section{THE BLUBBER AND ITS YIELD OF OIL IN DIFFERENT WHALES.}

The blubluer is a layer or banket of fat lying between the skin and the flesth or muscles and encompassing the bodies of all cetaceans and likewise of most of the other aquatic mammals. It varies in thickness from 1 to 20 inches, according to the species, size, and condition of the animals. 'The blubber of right whales is thicker, on an arerage, than that of the cachalot or sperm whale, although an individual of the last-named species has afforded fat 22 inches thick. The blubber of most species is tough and elastic, but that of the humplack is soft and yielding, and the ropes and (hains encompassing it tear out easily. The blubber of poor whales is hard, compact, and tenacious; but when the animals are fat it is softer and yields oil readily, even when handled. In color it raries from a yellowish or dirty white to a somewhat unusual pinkish or reddish cast. The whitish blubher is usually found on young whales, more especially sucking calves, and is of a milky appearance. That of old whales has a coarse gratn, and yields or gives out the oil freely; henes it is not so rlifficult to boil as is the fat of young whales, from which it is almost impossible at times to extract the oil, the texture heing so fine and close.

In case of the balcen whales the blubber from all parts of the animal is commingled and boiled together. With the sperm whale, however, the process of saring the oil is different. The most valuable oil of this species is found in a large cavity or reservoir known as the "case," situaterl anterior to the cranium, which yields clear oil and spermaceti, in equal quantities. These produets are known as "head matter." Lying beneath the case is a wedge-shaped mass of pinkish 
lat, rompesed of oil, spermaterti, and "whitr holse," the latst hering an extremely fough and simew blubler-like substance fomml about the

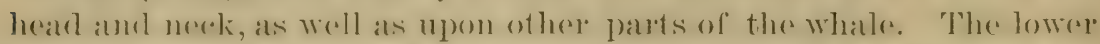

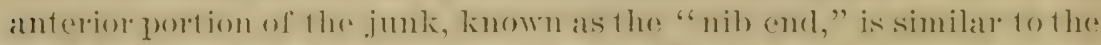

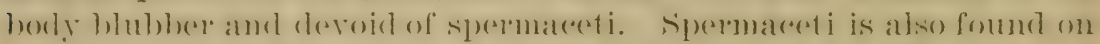

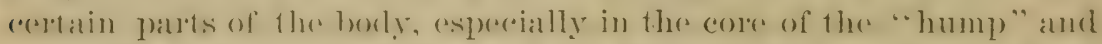

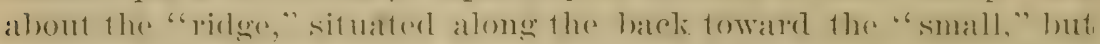
not in so great abundance as in the case. The yield of the head averatges ahout one-thirl of the total oil-product of the sperm whale. Instances have heen reporterl, howerer, in which it has heen sul per cent and even as high as 60 per cent of the total.

The following parts in the sperm whale ale utilizerl as an oil-yielel-

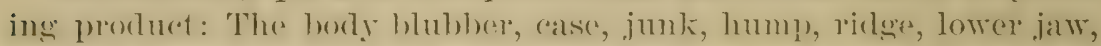
heatl skin, scall), small flukes, veptelure, and fin hones. The bones of all whales ane porous or sponge in treture, and the carities are filler] with moln or less oil. 'The small hones, such as the fin bones

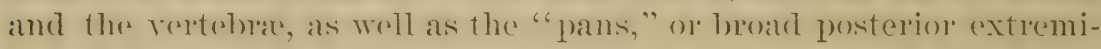

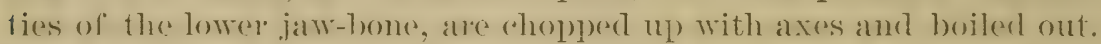

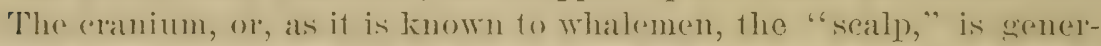

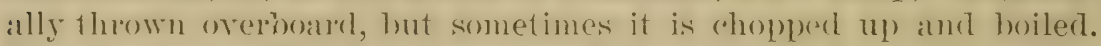
The "head skin," of the great mass of fat eovering the scalle, may he

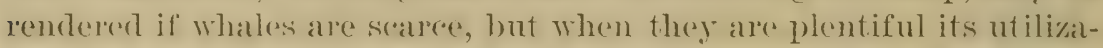
tion is not profitalole. Some of it is exreedingly tough, and the small quantity of oil it contains is difficult of extraction.

Whales are generally rated by the amount of oil which they yield rather than hy the sizo or length. The yield is expessed in barrels, and an animal may be a "40-barreler" or a "100-barreler." In appealane.e they are often deceptive, the largest ones not always yicleling the greatest amount of oil. L'sually the whalemen approximate the porduct with remarkalnle acculacy, but sometimes their. guesses miss the mark witely. IBluhber yields about to per cont of its weight in oil, + toms of blubher producing about :; toms of oil, wach containing 252 callons wine-meastme. Sperm whales yiek from 50 145 barrels of oil, areraging ahout 25 or 30 for the cows and 7510 sol for the bulls.

The oil-porducing parts of the right whales are the boty blubher; the tongur.; the heat geatr, comprising the hear, scalp, throat, lips, and head skin; and the blubber on the fins. The right whales yield a Jarerer quantity of oil than the catchalot, and the bowhead or Arefir whale yields a larger quantity than the right while of temperate waters. In 1861 the Gemert Pitie, of New Bectford, took a right whale on the Karliali wround which stowed town 2it barrels of oil. The schooner Lizzie P. Simmons, New London, killed a bowheat whale on Ocotohre 28, $18 s^{\circ}$, in Cumberland Inlet, which yichded

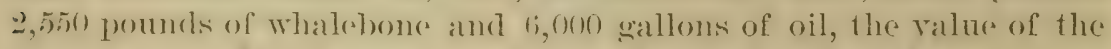

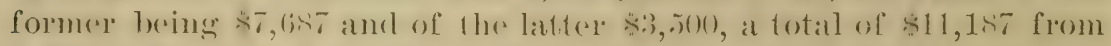
a single animal. Accordiug to whalemen, the right whales now (alp)- 
turecl are not so large as formerly, but the sperm whales seem to average about the same.

The humplack whales and the finhack whales of all oceans are frequently captured by deep-sea whalemen and of ten by shore whalemen, especially in the Finmarken fishery. Since both of these varieties usually sink when killerl, they are rarely hunted except "on soundings." "The oil-vielding port inns of the humphate are the body hlubber; hearl skin; lips, which are small; 10ngue; entrail fat, the source of a large pereentage of the oil, and the striaterl folds of fat on the breast and abdomen. The entrail fat resembles very closely in appearance the corresponding fatty substance of the ox; its oil is of tha same grarte as that of the hlubher of this species, which is equal in grate to the oil of right whales.

Not only are the oil and whalehone yielded by finhack whales much less in cutuntity, but they are also inferior in quality to those obtained from the right whales. For this reason, and also on accomnt of their great activity and the difficulty of rapturing them by harpooning, they were formerly neglected by whalers; but since the employment of steam ressels with bomb gums and explosive lances an extensive fishery for them has been established on the Norwesian and Newfoundland coasts and minor fisheries on the coasts of Russia and. Japan.

The California gray whale is occasionally taken in the lagoons of Japan and on the west coast of the United States. The oil-hearing parts of this species which are utilized are the borly hlubber, head skin, throat, lips, flukes, and entrail fat. Accorling to Capt. George O. Baker, of New Bedford, during several years following 1860 a lrigg from New Jedford, Mass., made quite a business of catching (alifornia gray whiales for the food markets of Japan.

The bottle-nose whale, so called from the peculiar shape of its head, yields on an arerage about 12 larrels of oil. The principal places where this species is raught are along the edges of the ice fields of northern Europe, Wetween Bear Island and Iceland, the fishery heing prosecuterl principally hr Norwegiaus hailing from Tönsherg and Sandefjord. Like the sperm whale, the bottle-nose possesses a quantity of oil in the cavity of the head, which yields spermaceti in the process of refinement. The hlubber oil of the bottle-nose comes next to sperm oil in quality. It gives no residnum, and is therefore employed for lubricating small machines, spindles in mills, etc.

Fesirles the above, a mumber of minor cetaceans are occasionally utilizel for their oil; among them the orea or killer whale, the narwhal, the beluga or white whale, the black-fish, and the porpoise. 'These have a coating of blubber ranging from one-half to $t$ inches in thickness, and, although not extensively sought after, many are taken in various parts of the world.

The heluga is plentiful in the Arctic seas and in the North Pacific and comparatively numerous on the Labrador coast and in the St. 
Lawence River, whepe it forms the object of a small but porfital)le fishery. 'The stoam-whaler's somet imes pulsue and capture it in great numbers in the Irefir, but omly when the Greenland whale can not be fomel, for the yolel of oil is smatl and the animal is so swift and active that it is not rearlily aptured. 'The atult is from 10 to 15 fect: in length, and of a creamy white color. The hlubher is about 2 ine hess thick, amel (ach animal yields from 20 to 100 gallons of oil excellent in lubricating qualities.

'The orea affords a goorl variety of oil, but owing to its agrgerssiveness it is not often attatekert hy the whalers. It has oceasionally heran captured on the New England coast, and has also been taken on the

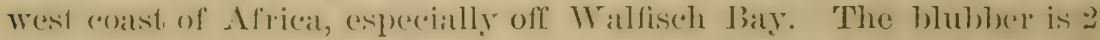
or :; inches thick, and simila" in colon and texture to that of the siserm whale.

'The matwhal yiclis a small guantity of oil, which is userl considerably by thr Eskimos and (x)eculanters. It is ordinarily rery pato in color, in fact almosti colorless. Tho narwhal is mot msually an oh,ject of pusuit hy our whalemen, as its capture is surrounderl with many difficulties, owing to its rotreats in the ioe floes. The valuable blark-fish and porpoise oils are discussed in a separate chapter.

The following tabulaterl statement of the yixld of oil from the several spereses of cetaceans has been prepared with much care after consultation with the most experienced whalemen of various ports:

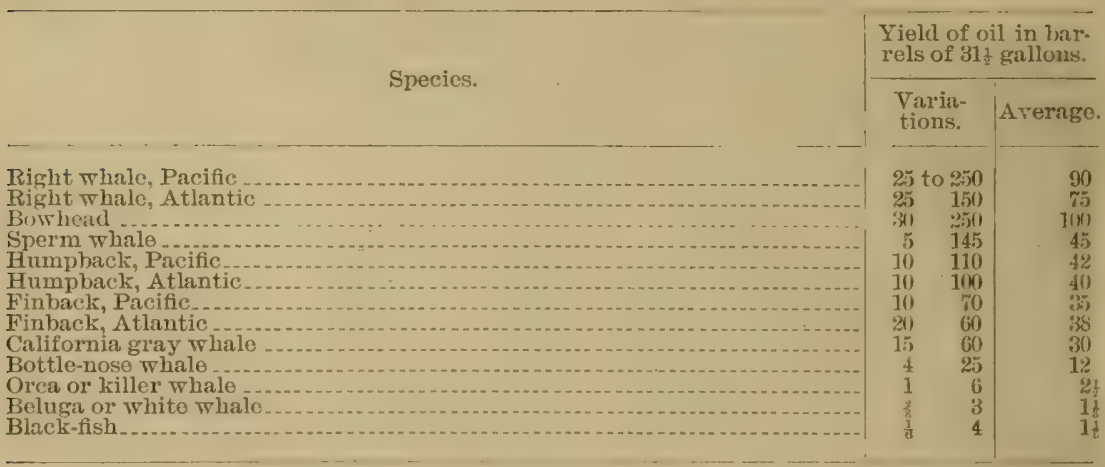

The methods of cutting-in aml removing the hlublor have already bern described hy numerous writers, and especially hy James Temple Brown, rendering mnecessary any extended description in this paper.

Suftice it to state that the whale is attached to the sirle of the resser, and hy cutting in a spiral line and at the same time rolling the cetacoan, the blubber is removed in a helical strip) or 6 feet wirle, and this is boarderl in lengths of 120r 15 feet, called "blanket-pieces." The manmer of doing this and of hoarding the heacl geat is germano to natutical enginorering whther than to the subject of oil-rendering. 


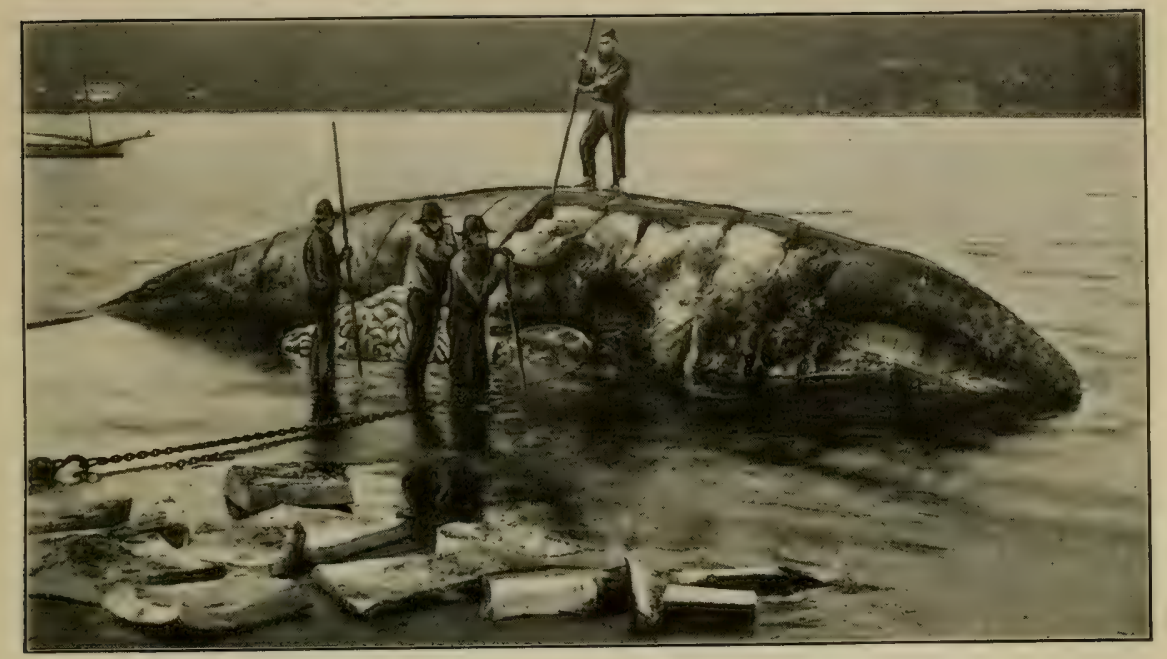

REMOVING BLUBBER FROM WHALE BEACHED ON CALIFORNIA COAST.

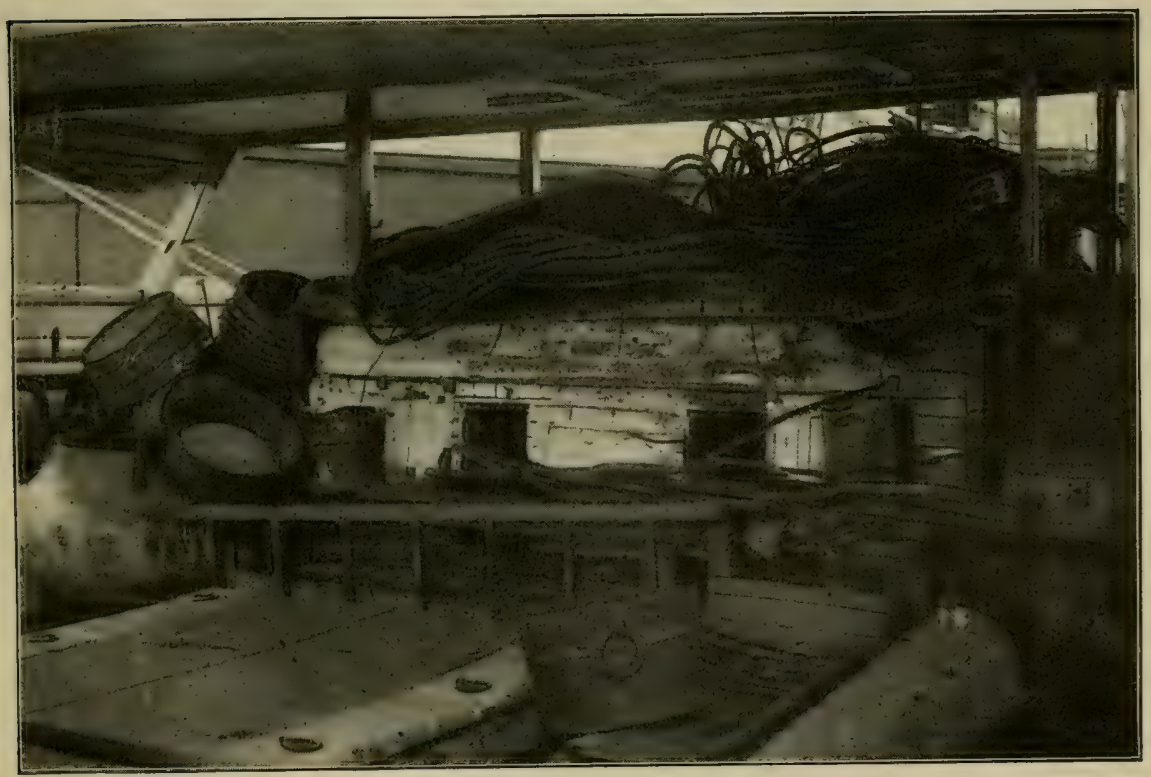

TRY-WORKS ON MODERN WHALER, LOOKING AFT. 



\section{CONVERSION OF THE BLUBBER INTO OIL.}

The following notes on the present methods of converting whale blubber into oil are the results of inquiries and investigations made by the writer during the last four year's, and especially in October, 1901, when many practical whalemen were interviewerl. Especially are we indebted to (apt. George (). Baker, (ant. Charles II. Robbins, (apt. James Avery, and Mrr. W. R. Wing, of New Bedford, Mass.

The reduction of oil from the solid mass of blubber, though tedious in detail, is an operation of simple character, requiring merely that the substance shall be exposed to heat. The blanket-pieces, 12 or 15 feet long and 5 or 6 feet wide, are first "leaned," consisting in removing the pieces of muscles which cling to the fat during the process of eutting-in. By means of sparles they are cut into smaller sections, called "horse-pieces," about 2 feet long and 6 inches wide. These are passed to the mincers. If the blubber is too thick, say over 12 inches, it is sometimes split before it is minced.

Two methods of mineing the blubber are employed, viz: by hand and by machinery. The former was the first adopter and is generally used at the present time. It is extremely laborious, but most whalemen prefer it, since the pieces are mincerl more uniformly and conseciuently the oil boils out more freely. The horse-pieces are laid lengthwise and with the flesh side downward upon a bench called the "mincing-horse," and are scored or cut into slices varying from me-fourth to three-fourths inch thick, called "minced horse-pieces." 'The knife cuts through the skin, but is stopped within about an inch of the base, so that the slices are held together like the leaves of a book, and in this condition they are pitched into the try-pots.

The try-works are built of brick athwartships between the foremast and the mainmast. The usual dimensions are 8 or 10 feet long, 7 or 8 feet wide, and about $4 \frac{1}{2}$ feet high. The first course of bricks, or the base, is laid in openwork, forming channels through which the water may freely circulate. The fireplaces, or "arches," as they are known abourd a whale ship, are streugthened by pieces of iron and are furnished with sliding doors. Two large metallic try-pots are placed within the try-works, with their bottoms resting upon the arches or furnaces. These are shaped like the old-fashioned 3-legged pots so intimately associated with the domestic hearths of our forefathers. They range in eapacity from 120 to 200 gallons each.

While boiling the blubber, the fires are kept up day and night. Naturally, the fuel supply is an item of no small consideration to the whalemen. A quantity of cord-wood, each stick sawed into two pieces, and all kinds of refuse wood are included in the ressel's outfit and relied upon for starting the fires. But when fairly under way the highly combustible residue of the fat, kuown as "scrap," is mainly lepended upon. Once in awhile a whale is secured so fat that the scrap is not sufficient to keep the fires going and the "fat lean" and

$$
\text { F. C. } 1902-13
$$


similat materials are burned, and sometimes even a part of the rich blubber is ansumed as fucl in order to sisere the remainder.

It is woll known that the boiling point of oil far excesels that of water. So intense is the heat at times that the solder upon the implements used about the pots is melted. It is important that all water should be expelled in order that the oil may not become rancid when barreled. It is eyually important that erery precaution should be taken to prevent water from getting into the pots during the process of boiling, the action of the oil under such eiremustances depending upon the quantity of the extraneous fluid which is suddenly brought in contact with it. If the pots are not sheltered heary rain may cause the oil to foam up, and when the vessel ships a heary sea or when a very heavy rainstorm oceurs, the contents of the pots are apt to throw up an immense cloud of steam and scatter the seething oil. Communicating with the fire, the oil is ignited with a flash, and the streams of burning liquid pour out upon the deck, sometimes with disastrous effect. Is noon as the contents of the pots show a tendency to boil over, piecess of fresh blubber are pitched in, and if this is not sufficient the fire is immediately banked.

To prerent the vagrant pieces of lean which have accompanied the blubber from clinging and burning to the side and bottom of the pot and thus darkening the oil, the hoiling mass is vigorously stirred. 'This is one of the most important duties in the process of oil-rendering.

Instruments are never user on a whale ship for testing the heat or culinary condition of the oil; the men rely mainly on their experience as to the best time for removing it, judging either by the color of the serap or hy spitting into the boiling mass, this producing a peculiar crepitating noise when the blubber has been sufficiently cooked.

As fast as the pieces of hlubber are resolved into oil, the residuary fragments are transferled to a rough box called the "scrap-hopper" or "strainer-cooler." Its size depends upon the dimensions of the try-works, but usually it holds from 1 to $1 \frac{1}{2}$ pots of serap. It consists of two compartments, the upper portion, or hopper, for the serap and the lower part for the oil, the two separated by a wooden partition containing numerous holes, so that the oil may realily drain from the material.

The hest and most economical way of utilizing the scrap has always been an important problem to the whalemen. The boly of the sperm whale uswally hoils out freely, and consequently the scrap is dry, contains little oil, and is valuable only as fuel. The refuse of the right whale, however, retains considerable oil, and the whalemen are arerse to huming it until after they have extracted the oil by compression. The scrap from both the sperm and the right whales is recarderl as an important fuel supply and is economically saved at "ach fare during the voyage and used for boiling the blubber of whales taken subsequently.

Although the oil may be thoroughly rooked when the first scrap 
is remover, it is not bailed off, the usual plan being to fill the pot with fresh blubber and again boil it down motil the pot is full. In this manner the hot oil melts the cold blubber and the latter reduces the temperature of the oil already rendered.

The bones of cetacea contain more or less oil, but they are utilized in oil-rendering only when whales are scarce. On a cood royage the endoskeletons are thrown overboard as fast as the coating of fat is removed, provided they are not required for fuel.

The blubber of the "small" and the lobes of the flukes are cut into lorse-pieces and hoiled out with the boly blubber, heing of the same nature. The entrail fat of the humplate whale maty be boled by itself or with the hluhber, whicherer is more convenient, the oil of the fat anc that of the blubher heing of the same grade. The fins of the sperm whale are cut up with spades; the fatty rovering is hoiled with the body blubber, and the bones with the fat-lean. The oleaginous covering of the fins of the right whale is eut inte horse-pieces and boiled with the body blubber; the fin bones of this species are rejected. The head skin, or the fatty covering of the crown of hoth the right and bowhead whales, and, indeed, the "headgear" of hoth, are "ut into horse-pieces and run through the pots with the body blubber.

The tongue of the bowhead as well as of right whales is also reduced to horse-pieces and boiled out. The tongue blubber is close-grained, or of much finer texture than that of the ordinary blubber, and is usually boiled out last. When "green" its oil is extracter with great difficulty, if, indeed, this can he accomplished at all when cooked by itself, unless very finely minced; hence it is sometimes lair aside and run through the pots in easy stages with the borly blubber of the next cut. A muscular, fibrous substance known as "plum puclding" permeates the blubber of the tongues of these 1 wo species of whales, extending longitudinally through the central part and in greater abumelance near the roots. Most of it is utterly worthles's and is thrown overboard when detached from the fat of the tongue. It times, however, when the fat predominates, the "plum pudding" is saver and boiled out with the tongue or the refuse of the whale. It is almost impossible to render it when cooked alone.

The "ginger rolls," or plaited folds on the throat and hreast of the humpback, are cut into horse-pieces and rendered with the body blubber"; but the intermecliate substance, resembling "white-horse" in some respects, is extremely tough and elastic, and is absolutely worthless as an oil-yielding substance.

In trying out a sperm whale, either the body hlubber or the head matter, including the junk and case, may be boiled ont finst; hut they are never cooked together, since it is not policy to mix the oils, the head oil being worth a cent or two per gallon more than the hody oil. The manner of preparing the case and junk for the pots being different, they will be described separately.

If the body blubber is tried ont first, the head matter is deposited 
in junk ansks as fast as it is whipped or bailed from the case. The junk is reduced to horse-pieces, placed in similar receptacles, and held in reserve with the hear matter until the body blubber has been disposed of. The junk easks are ordinary oil casks with one head removed, and vary in capacity from 100 to 300 gallons each. They are also used to hold the serap which is saved as fuel. Instead of the casks some of the larger vessels have one or two tanks between decks, which are used as temporary receptacles for the head matter and also for storing the oil.

When ready to boil out the head, the try-pots are well serubber, greater care being taken than when boiling the body blubber. They are next about half filled with some of the head matter as soon ats it is bailed from the ease, the remainder being stowed atwa as just mentioned. With legs and feet bare, men get into the pots and, standing in this odorous compound, squeeze out the soft pieces of fat. The oil flows freely between their fingers into the pots, while the refuse, called "twitter," is thrown into another receptacle, called the deck-pot, or perhaps into scrap-tubs. Notwithstanding the many improvements that have been made in the oil industries, no process of eliminating this membrauous texture from the crude sperm oil has yot heen discovered except the one just referred to-that of squeezing by hand. It is necessary to remove these fibers to prevent them from charring and darkening the oil. The case being carefully squeezed, the fires are started and the cooking then commences. The pots are spaded constantly to prevent the small but sometimes numerous particles of twitter, which have not been removed, from burning against. the sirles and bottoms. Meantime other men are squeezing out the remainder of the head matter deposited in the junk cases, and this is kept in scrap-tubs and poured into the pots as soon as the first installment has heen properly cooked and bailed off, this operation continuing until all the head matter has been boiled out.

IV hile the case is boiling, some of the crew ent the junk into horsepiexes somewhat larger than the body-blubber horse-pieces, and these sections, after mincing, are pitehed into a pot of thoroughly cooked hearl matter. The hot oil of the case soon dissolves the junk, the two mingling most intimately, being of a kindred nature. Sometimes the case and the junk are boiled separately.

White-horse in considerable quantity ranges through the juuk in strealss. It is tougher and whiter in large whales than in small ones. The fatty substance found between these layers, or strata, is softabout the consisteney of butter-and is of a pinkish cast, resembling somewhat in color the meat of a watermelon. The white-horse of large whales, especially of an aged male, is remarkably tough and is detached by means of sharp cutting-spades and thrown overboard. There is little oil in it, and its extreme toughness prevents it from being minced. If attempts are made to boil it out with the junk, it usually soaks up more oil than it yields. But the junk of small whales, more 


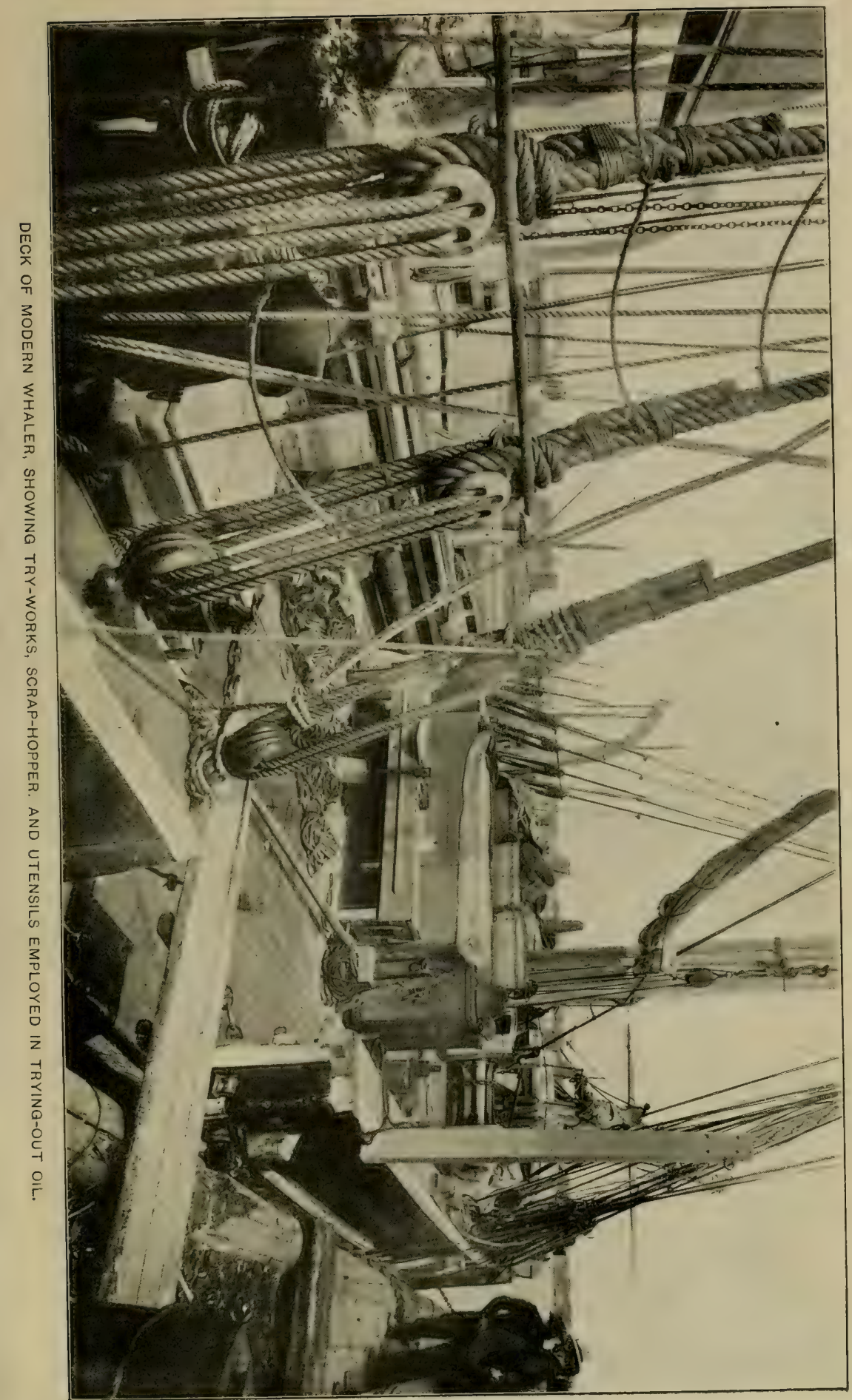



particularly the cows, ineluding both the white-horse and the fat, may be cut into horse-pieces, minced, and boiled out together. The process of mincing the pieces of junk and pitehing them into the try-pots is identical with that previously described in conuection with the body blubber. While some of the men are cutting out the white-horse and preparing the junk for the pots, others are seraping up the oil, which flows out profusely during the operations.

The hump and ridge of the sperm whale are cut into horse-pieces and boiled out with the head and with the fat secured from the jaws.

The term "twitter," which has been previously referred to as applied to the thread-like or" membranous substance ranging through the contents of the case, is also applied to the lining of that reservoir. This is from 2 to 3 inches thick, glutinous, and extremely tough. In decapitating the sperm whale, especially in severing near the bunch of the neck, a very sharp spade is required to cut through this toug: and elastic formation. Although it is very difficult to manipulate, an economical whaleman never throws this substance away. Since it can not be boiled out with the case, for the reason above given, it is saved and run through the pots with the fat-lean after the case and junk have been cooked.

There are two kinds of "lean," the "clear-lean" and the "fat-lean." The clear-lean, as the term signifies, is composed almost entirely of muscles, and is rejected as utterly worthless to the uses of whalemen. The fat-lean is eomposer of fat and lean so intermixed that separation by means of knives is impracticable. It is obtained principally about the jaw, as well as from other external parts of the whale. A large portion of it is cut from the blanket pieces during: the process of leaning. When whales were abundant, the fat-lean was thrown away, but at present many, if not all, of the whalemen convert it into oil after the oil from the head and body blubber has been bofiled out and bailed off. The fires are then drawn, the try-works cooled down, and the fat-lean is pitched in. This is a delicate operation, and if not performed in the proper manner there is danger of eracking the pots. Water is usually placed in the pots first and the fat-lean is pitched in until the pots are about two-thirds full, and then the twitter and lipperings are adrled. The fires are started, the admixture brought to the boiling point, and the works are again cooled down. When cold the oil floats upon the surface, and the water and cracklings remain at the bottom. If the process has been skillfully conducted, the oil may be almost as light and clear as any obtained from the better and purer parts of the whale. As a rule not more than two pots of this substance are boiled down, for the oil obtained from it is generally more or less sour-a result probably from either mixing it with water when boiling, or because it had become tainted through decomposition, or it may be due perhaps to both causes. This oil is usually barreled separately.

The oil obtained from the fat-lean of one whale is sometimes mixed 
with that obtained from the blabber of the next capture, this being effected hy putting a few gallons of it into the cooling tank every time a pot of the subsecuent fare is bailed off. Notwithstanding the imporbance of keeping the different grates of oil separate, some whalemen alulterate the blubber oil to a greater or less degres by the addition of fat-lean oil, yed they are prudent mough to save several casks of the latter grate to show on their return that the fat-lean has not only been ecomomically saved, but also that its product has not been mixed with oils of higher grades.

The slivers, or small pieces that have been cut and hacked from the blubher while reducing it to horse-pieces and mineing it, are also saved and boiled with the blubber. The "slumgullion" and "lipperings" or "dreenings" of the blubber-consisting of a mixt ure of the blood which issues from the fatt-lean and the salt water and oil which flows from the blubber while the men are handling it as they hoist it aboard ship, stow it away, and prepare it for the try-pots-though discarded in the palmy dalys of whaling, are now earefully husbanded and amalgamated. Like the sweepings of the floors of mints, this liquid refuse of the eatch is refined in the whaleman's crucible in order that nothing may be lost. After the solid matter has been disposed of, both the deck lipperings and the blubber-room lipperings are usually deposited in barrels ortubs and there sealded with hot oil. The oil thus olstained is rakexl off and transferred to the cooling tank. In case the lipperings are not clean they are cooked with the fat-lean.

"Slush" is the skimmings from the tops of the pots, and is usually saverl by the rook, who is commonly entitled to one-half of it. On arrival home it is sold to manufacturers of soap, and it is even elarified and mixed with lard. At sea the whalemen sometimes eat the slush as a ciressing in the form of gravy on sweet potatoes, ete., but it is douhtful if they could be incluced to (at, it ashore, although it is quite clean and nutritious.

The different varieties of oils are barreled separately. A cask that has contained whale or humpback oil should be thoroughly eleansed before putting sperm oil into it, but a cask that has been used for sperm oil neerl not be cleansed should it be neeessary to use it for whale oil; the small quantity of whale oil that might be left in the eask would perhaps make the sperm oil somewhat heary, but a little sper'm oil would not injure the whale oil. The casks of a ship engaged solely in right-whaling are not marked at all; should the ressel incidentally catch sperm whales, the casks containing oil from this speciess are marked s O, and the other casks are supposed to contain whale oil. Casks containing right-whale oil taken by a sperm-whaler are mirked $W^{\circ}$ or $W^{\top}$ o. The hear oil of the sperm whale, unless the quantity he very small, is always kept in separate packages, which are marked II; those containing the borly oil of this species are marked $S()$ or sp (). The packages of fat-lean oil bear the initials F L O, anrl hack-fish vil B F O. Except when large catches are made, black- 
fish oil may be kept in meat barrels. The lettering is done in white paint, on the heads of the casks. When the oil is shipped home by another vessel the name of the ship is also branderl on the eask, the impression being made with an implement ealled the "ship's marking" iron," and the casks are numbered consecutively.

\section{REFINING SPERM OIL AND WHALE OIL.}

The rendering and care of the oil on shipboard having been described, there remains to be discussed its further treatment for commercial purposes, especially extraction of the foots and bleaching. The headquarters of the refiners of whale oils in the United States are at New Berford, Mass, and San Francisco, Cal. Twenty years ago New Bedford monopolized the business, but large refineries have been erected at San Francisco, and at present about 20 per cent of the sperm oil and 60 per cent of the whale oil are refined at that port. The subjoined description is prepared almost wholly from information furnished by the principal refiners of New Bedford in 1901. The writer wishes especially to acknowledge, in this connection, the courtesies of Messrs. William A. Robinson \& Co., and of Messis. Frank L. Young \& Kimball.

As received at the refineries, the casks of oil have been inspected and gaged by customs officers. They may have been kept in storage for months, and in some cases years, before reaching the refiner. Formerly, on the wharves at New Bedford might be seen thousands of casks filled with oil awaiting sale, being preserved from great leakage in the meantime by a covering of seaweeds; but in recent years the quantity has been much reduced, and on the occasion of the writer's last visit to New Bedford (October, 1901) not a single barrel of oil was on the wharves.

The oil is of two principal kinds, viz, sperm oil and whale oil, the former being obtained from sperm whales and the latter from all other varieties of whales and also from wahrus, black-fish, sea-elephant, etc. It ranges in color from clear amber to very dark brown, depending on the variety of animal, the condition of the blubber, and the success of the rendering. The quality is determined by appearance, odor, and flavor. There is some difference in the ralue of crude oil of the same species of whale from Northern and from Southern seas, the former selling for a few cents more per gallon. Crude sperm oil was formerly worth about double the value of whale oil, but in recent years the difference has been much less. Little use is made of unrefined sperm oil, but considerable of the product of whale oil is sold in a crude state to steel-workers, miners, and cordage-manufacturers.

The products from refining sperm oil are the "winter sperm," which is the first running from the crude oil after it has been granulated by refrigeration; the "spring sperm"; the "taut-pressed," and spermaceti. The refined sperm oils are not generally sold in their natural color, however, but are usually bleached by a process which leaves 
"sperm-oil soap" as a proluct. "The products of whale vil, including that of walrus, black-fish, sea-elephant, ofc., ale the winter, spring, and summer pressings, a tallow-like substance known as whale foots, and "oil soap."

Sperm oil.-The two varieties of oil obtained from sperm whales, viz, body oil and head matter, differ greatly in appearance. The former is of a light straw color, while the latter when first taken from the head of the whale is as clear and limpid as water, but after a short time thickens and hardens into a white mass. Each animal is sup)posed to yield about two-thirds body oil and one-third head matter. These are keptseparate on shipboard, but when received at the refineries they are generally mixed in natural proportions and together submitted to the processes for separating the oil and spermaceti.

In the process of refining, the crude oil is drawn from the casks and heated for the purpose of rriving off all the water. This is conveniently done hy rumning it into large iron tanks of several hundred, or even thousand, gallons capacity, where it is subjected to heat by means of coils of steam-pipes rumning around the inside of the tanks. When heated in excess of $212^{\circ} \mathrm{F}$. all moisture is soon expelled, and the oil resists water; that is, water will refuse to mix with it and will "snap" when dropped into the oil. By continuing the heating from six to ten hours the crude oil is converted into a clear liquid state, all particles of fat and blubber boiling out and the impurities settling at the bottom of the tank. 'The steam is then shut off and, after the oil has partly cooled, it is drawn off from the top of the tank into barrels or casks with capacity of about 50 gallons each. The secliment which precipitates at the bottom is drawn off and made into soap.

In the barrels the oil is chilled. In cold weather, from December 1 to March :31, this is done by exposing the barrels and their contents to the weather; but during the balance of the Jear it is necessary to place them in large covered pits, where the oil is frozen by using ice and salt packed among the barrels. To avoid the expense of artificial refrigeration, it is preferable to do the refining during the winter season.

After remaining in the pit from ten to fourteen days, at a temperature of about $32^{\circ} \mathrm{F}$, the oil is thoroughly chilled, shrinks, and separates or granulates into little balls or grains. It is then removed from the refrigerator, shoveled from the barrels into canvas or hempen bags holding from 2 to 4 gallons each, and placed in a press, where it is subjected to a pressure of from one to two thousand pounds to the square inch. There is thus pressed out a clear, cold oil known to the refiners as "winter sperm oil," which will stand bright or will not congeal at a low temperature fixed as a standard. Formerly the standard was $32^{\circ} \mathrm{F}$., but at present the usual commercial test is $38^{\circ} \mathrm{F}$. Oil of $23^{\circ}$ F. test has been prepared, but there was no demand for it. Since the lower the temperature at which the congealed oil is pressed the less the quantity yielded, it is not desirable to use any lower temper- 


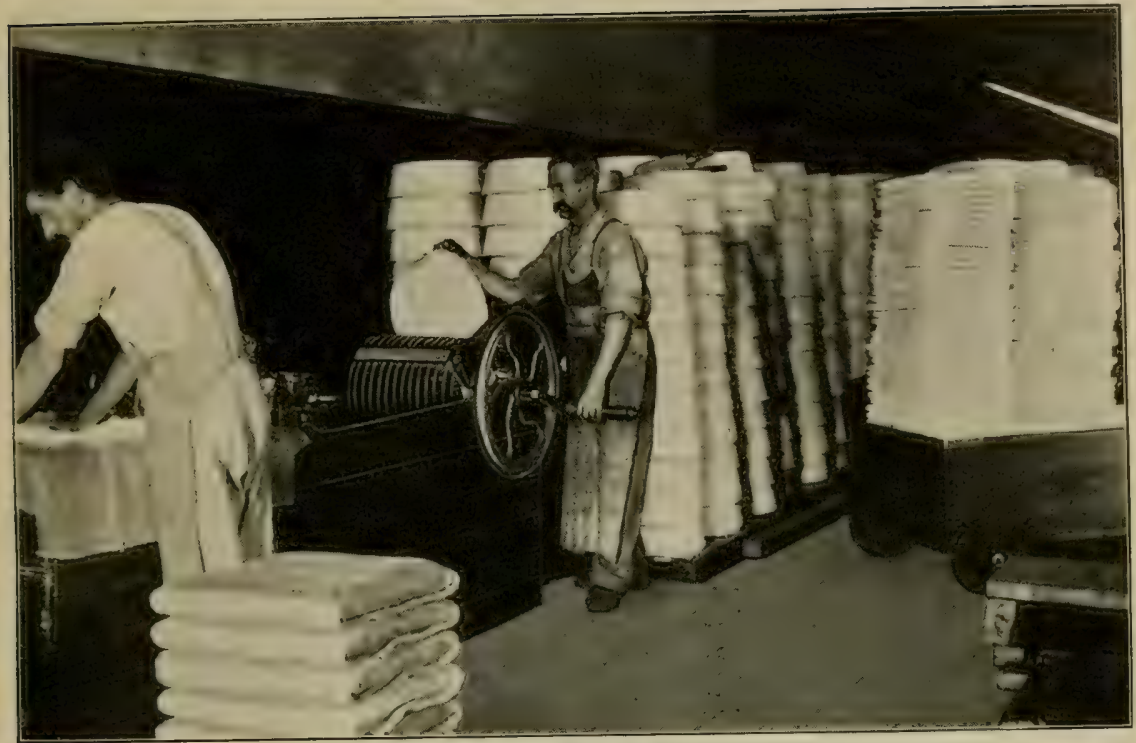

GRINDING AND PRESSING CRUDE SPERMACETI FOR REMOVAL OF TAUT-PRESSED OIL.

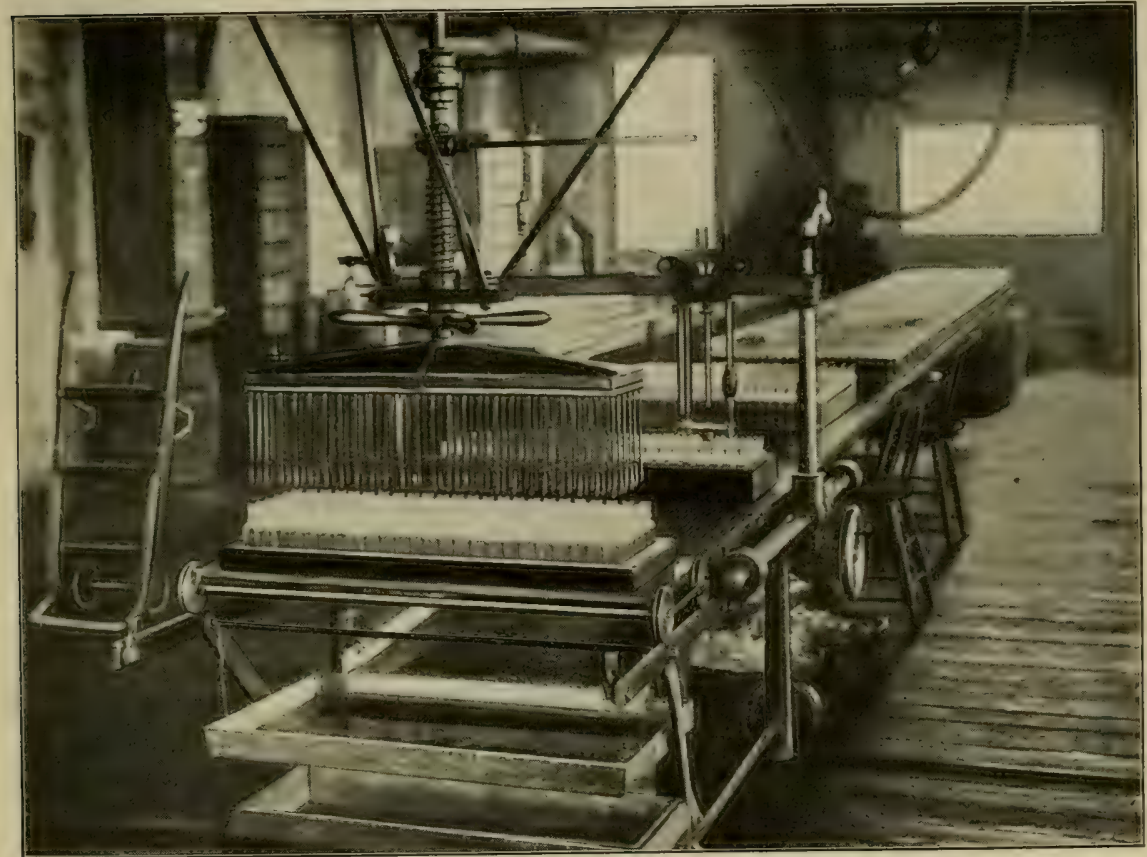

INTERIOR VIEW OF OIL REFINERY. FILLING BOTTLES WITH SPERM OIL. 

ature than required. When producing oil of $38^{\circ} \mathrm{F}$. test, the amount of "winter sperm oil" yielded is about 75 per cent of the original quantity. In former times when a $32^{\circ} \mathrm{F}$. test was used, the "winter sperm oil" was about 67 per cent of the original bulk. This may be sold either in its natural state or bleached. It is used principally as a lubricant, and, to a less extent, as an illuminant in mines.

After the "winter sperm oil" has been pressed from the bags there remains in them a solid of a brownish color, which is again submitted to pressure at a warmer temperature, say $50^{\circ}$ to $60^{\circ} \mathrm{F}$., and there is produced an oil known as "spring sperm oil," which congeals at the test of $50^{\circ}$ to $60^{\circ} \mathrm{F}$. above noted. The quantity of "spring sperm oil" is about " per cent of the original quantity of crude oil.

The solid now remaining in the bags is emptied into receptacles and, after remaining for several days at a summer temperature, is dumped out in the form of solid cheese-like cakes. These are stored where the temperature is kept at about $80^{\circ} \mathbf{F}$. and in the course of a week or so are shaved up by revolving knives and again bagged and suibjected to a pressure of about 100,000 pounds to the square inch. This yields a third grade of oil called "taut-pressed oil," which will chill at a temperature of $90^{\circ}$ to $95^{\circ} \mathrm{F}$. The quantity of oil of this grade is about 5 per cent of the origimal bulk, making a total of 8.1 per cent of refined oil obtained. The residue in the bags after the extraction of "tant-pressed oil" is erude spermaceti of a brown color, which will melt at a temperature of $110^{\circ}$ to $115^{\circ} \mathrm{F}$. The methods of refining spermaceti are set forth on page 245 .

As refiner at the present time, sperm oil, including both body oil and head matter, yields about 11 per cent of crude spermaceti and 8 ? per cent of refined oils, in the following proportions: 75 pel cent of "winter sperm," 9 per cent "spring sperm," and ó per cent "tautpressed oil." A barrel of crude sperm oil of $31 \frac{1}{2}$ gallons, weighing 231 pounds, yields 25 pounds of refined spermaceti, 23.6 gallons of "winter sperm," 2.8 gallons of "spring sperm," and 1.5 gallons of "tautpressed oil." The prices of these (January, 190:) are: Spermaceti, 23 to 24 cents per pound; winter sperm, 75 to 77 cents per gallon; spring sperm, 60 to 61 cents; taut-pressed, 50 to 53 cents, and sperm soap 3 conts per pound; a total of about $\$ 24.50$ resulting from one barrel of crude oil.

Sperm oil is one of the most characteristic and raluable oils in commerce. It is very generally conceded to be the best lubricator in existence for light, rapid machinery, such as the spindles of cotton and woolen mills, its viscousness, tenacity, and high flash-point causing it to work with great uniformity and with a small amount of friction. But there are many cheap substitutes-made from petroleum principally-which, though not so good, answer the purpose nearly as well; consequently the demand for sperm oil is far less than formerly, and even much of that sold as sperm contains a large admixture of hydrocarbon and other oils. 
IThere vil.- Whe "olor" of whale oil depends on the "age" of the blublure, or the time that elapses between the deatle of the whale aud

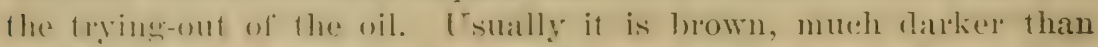
sperm wil, with at slightly disagreathe orlor. In a crude state it is

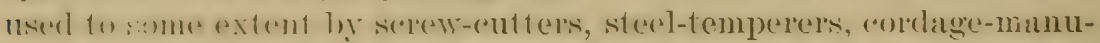
far.turer's, ainl as an illuminant for miner's' lamps, but more than half is refined in a mamer similar to the treatment of sperm oil. The first boiling and frexing processes are the same as with spermoil. When remover from the refrigerator the eongealed mass is usually dumped on woolen strainer's, 2 feet wide and from 10 to 2 () feet in length, stretcherl alcross frames. The process of straining is employed to reduce the bulk, sinee much oil will pass through the woolen cloth and leave a less quantity to be pressed. The thick part remaining on the strainers is platerel in bags, ats in case of sperm oil, and subjected 10 great pressure. The fir'st oil from the press congeals at $336^{\circ}$ to $40^{\circ}$ F. and is callerl "winter whale oil." The foots or stearin that remains in the bags, areraging one-tenth of the original bulk, and about the consistency of leaf lard, is ustally white and clean. This may be reheaterl and refrigirated, aud upon a second pressing yields "spring whale oil "of a higher degree test; but this is not frequently done.

The oil with the foots removed may be sold in its natural color or it may be bleather. One-eighth of the whale oil and probably half of the sperm oil is blenched by the refincrs. In this process it is first placed in the refining tanlis and heated. When partially cooled the water and sediment are drawn off from the bottom of the tank, and while the oil is agitated or stirred some soda ash or eaustic soda is added. This so acts on the oil as to cut the gum, and the thick part settles to the bottom, leaving the oil clearer and of a lighter color. It is also aceomplished by exposing the oil under a glass roof to the sunlight for a few hours, or even clays, in large shallow vats ò pans from 3 to 1: inchess reep, calch witl ciupacity for sereral hundred gallons.

The refuse in the bottom of the tanks is drawn off and boiled down into oil soap), which is worth about 3 (ents per pounc. The first bleaching will give about 2 per cent in hard soap, the second and third each give about the same. If the oil is clear and sweet the first bleaching is suflieient. Mruch of the oil soap is shipped to (alifornia, Florida, and other frut-growing sections, where it is employed as a wash for trees to protect them from the ravages of inseets. It is also used to some extent in fur-diressing.

In the usual pressings, the oil of the right whale taken in high northern latitudes gires about $s$ per cent of foots or stearin; if taken in the vieinity of the equator, or south of it, about 15 per cent of stearin is yielded. ILumplack and finback oils yield about 12 per cent of foots; seat-elephant yields 5 or 6 per cent; meuhaden from 5 to 10 per cent; and seal oil yields only 3 or $\frac{1}{t}$ per cent in the eustomary pressings. Of course this varies according to the temperature at which the oil is pressed. Tallow regulates the price, in a measure, as 
the stearin is substituted to quite an extent for that article. The market price approximates 5 cents per pound. It may be refined in a manner similar to spermaceti, though it is generally sold in the wude shape, packed in barrels. The chemical constituents are mainly glycerides of stearic and palmitic acids, mixed with oil. It is userl prineipally as a sizing for yarns, smaller quantities being used in Europe for smearing sheep after shearing. Other uses are in making soaps and in filling or stuffing leather.

The various whale oils are hard and strong, and range in specifie gravity from 0.900 to 0.927 at $59^{\circ} \mathrm{F}$. Oil of the right whale has specific gravity of 0.925 to 0.927 at $599^{\circ} \mathrm{F}$. Oil from the humplack and likewise from the sulphur-bottom whale is somewhat lighter in weight, the specific gravity varying between 0.915 and 0.920 at $59^{\circ} \mathrm{F}$. As, cording to Brannt, the composition of right whale oil is carbon 76.85 per cent, hydrogen 11.80 per cent, and oxygen 11.35 per cent; while that of humpback and sulphur-bottom whales is carbon 77.05 per cent, hydrogen 12.05 per cent, and oxygen 10.90 per cent. Refined whale oil is extensively used in machine shops to reduce friction, particularly in cutting bolts and screws. It is also used as stuffing in leather-dressing, especially in the manufacture of chamois leather.

The following summary, compiled from the trade journals, shows the range of prices per gallon for crude sperm oil and for whale oil during a series of years ending in 1901:

Statement of the maximum and minimum prices per gallon of sperm and of whale oil each year from 1868 to 1902 , inclusive.

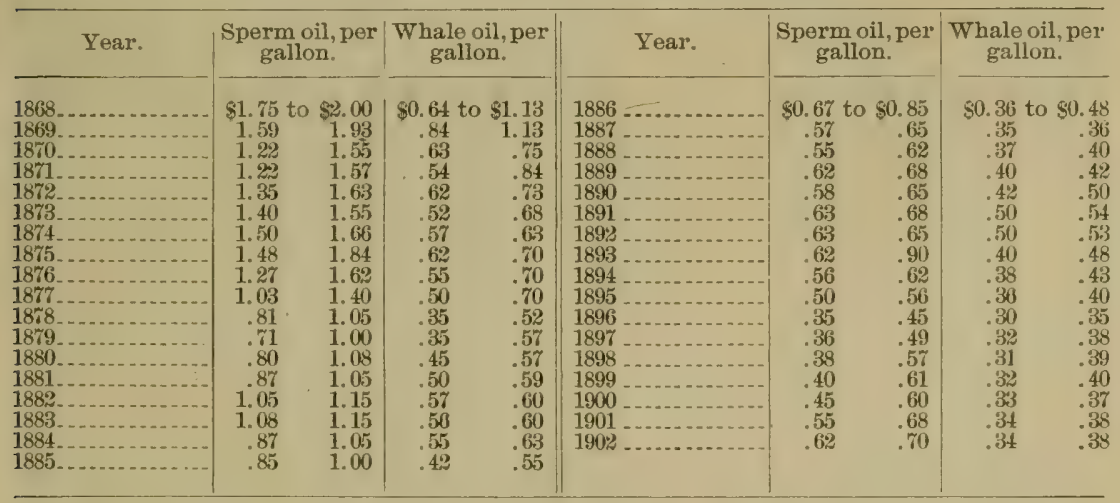

In the early years of the whale fishery nearly all the sperm oil produced in the United States fisheries was exported in a crude condition, and during the period of greatest prosperity in the fishery about onehalf was exported, but at present the exports in a crude state are very small. For the first time in a hundred years none whatever was exported in 1901. Most of it is refined at New Bedford, and some of the refined oil and a large percentage of the spermaceti are exported. Of the whale oil the greater part is consumed in this country. 
The ammual product, of sperm and whale oils, quantities exposted, and guantities comsumed in this rountry, are shown in the following:

Table showing, in burels of in gallons each, the production of sperm and whale vils by the alhalingylect of the United Stutes, the export to foreign countries, and the home consumption from 1860 to 1901.

[Compiled from the Whaleman's Shipping List.]

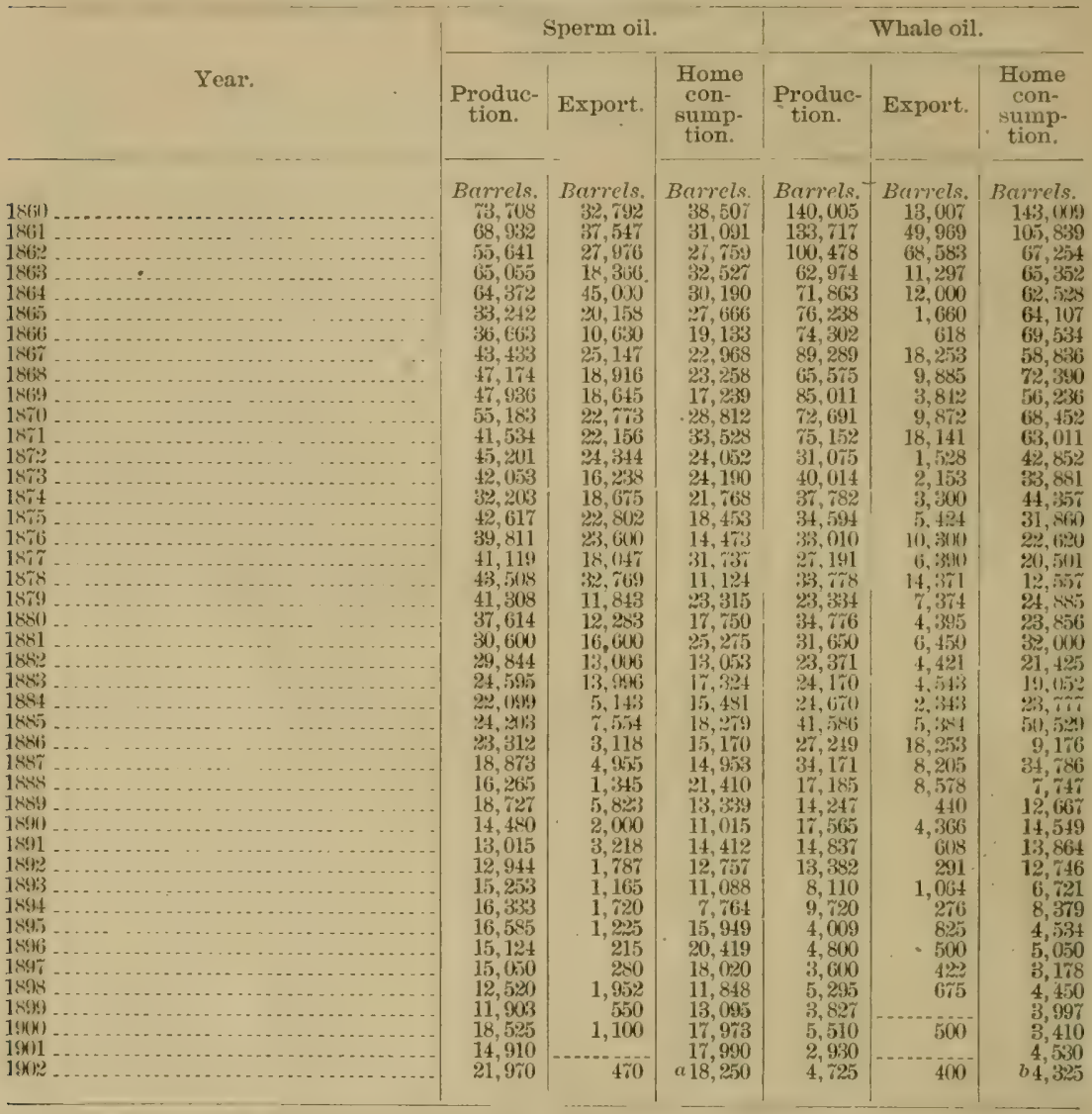

a On hand Jan. 1, 1903, 3,600 barrels sperm oil. b There was no whale oil on hand Jan. 1, 1903.

\section{PORPOISE AND BLACK-FISH OILS.}

Among the minor oils of technical importance are those of porpoise and black-fish, which are nearly equal in texture and are used for similar purposes. These oils are in two grades of widely different characteristics, viz, blubber oil and hear or jaw oil; the former is worth about the same as right-whale oil, or 35 cents per gallon, while the latter sells as high as $\$ 10$ per gallon. They are generally linown as "porpoise oil" and "porpoise-jaw oil," respectively, although the black-fish yiclds many times as much oil of each grade as the porpoise.

Porpoise have at times been taken in considerable quantities in shore fisheries established primarily for securing the hides for tan- 
ning purposes. $\quad 6,450$ porpoise secured on the North Carolina coast in 1887 yielded 10, 160 gallons of body oil; 2,283 porpoise in 1889 yielded 3,897 gallons, and 1,747 in 1890 furnished 2,746 gallons.

This oil is pale yellow to brown in color, and has a slight fishy odor, which disappears on exposure to air. The specific gravity, according to Brannt, is 0.918 at $590 \mathrm{~F}$, and it congeals at about $3^{\circ} \mathrm{F}$. Then fresh it is indifferent to litmus paper, but absorbs acid properties from the air. It is used for tanning purposes and in componnding with mineral lubricating oils.

The sperm-whalers of the Atlantic occasionally harpoon IIatteras jorpoise from the bow of the ressel and lift them aboard for food purposes. In many cases the blubber of these is removed and tried-out for oil. This blubber is of a yellowish white or porl color, varies in thickness from $\frac{1}{2}$ to $1 \frac{1}{2}$ inches, and is of about the same texture as that, of the belugar or white whale. It is cut in longitudinal strips 4 or 5 inches wide, minced, and placed in the try-pots with other blubher. The yield of oil is usually less than 2 gallous to each animal, consequently the whalers do not often render it.

From the jaw-pans of porpoise taken more particularly for food, the whalers obtain the highly renowned "porpoise-jaw oil," which is used for fine lubricating purposes. The lower jaw is removed from the head, the pans extracted therefrom with a knife, minced, and placed in a small tin, such as a meat-can, and placed on the stove to simmer or boil gently. The quantity of oil obtained from each jaw is very small, probably about one-half pint, and the total quantity secured by the whaling fleet of New Bedford probably does not exceed 5 or $6^{\circ}$ gallons anuually, the market price of which is upward of $\$ 6$ or $\$ 8$ per gallon.

Some years ago the Passamaquoddy Indians on the Maine coast captured numbers of porpoise. Indeed, at one time that fishery furnished their principal means of support. As the animals were taken mostly during the winter and inshore, where food is abumdant, they were very fat. The largest individuals measure about 7 feet in length and 5 feet in girth, weighing 300 pounds or more. The blubber of a large porpoise is from 1 to 2 inches thick and weighs 75 pounds and upward, yielding 5 or 6 gallons of oil, but the arerage for all taken was only 2 or 3 gallons. In the primitive method employed by the Indians, the blubber is stripped off and cut into small pieces, which are placed in a large pot. Inside a semicircle of large stones a fire is made, and when the stones are hot the fire is scattered and the pot containing the fat suspended over the stones and sufficient fire kept up to insure the melting of the blubber. The oil rising to the surface is skimmed off and placed in suitable receptacles. This oil, when pure, formerly sold for 60 to 80 cents per gallon, but was frequently adulterated with seal oil and sold at less price. It gives an excellent light, and also is good for lubricating machinery, as it is free from sticky characteristics and has quite a low weather-test. The superior oil in the jaw-pans is 
also extrated hy hanging the jaws in the warm sunlight and permitting the oil to drip into cans placed underneath to receive it. About half a pint of this oil may be secured from each porpoise; it is sold at a very high price for lubrienting watehes, clocks, and the like. Very few of the Passimatumody Indians are now left, and these few have almost rntirely albandoned "porpusin" for" other" occupations.

The "black-fish" (Globiocephatus melas) oceurs in many" parts of the Atlanticocean. Individuals vary in length from 8 to 22 feet. They are (a)p ured hy the sperm-whalers, and also at irregular intervals they are secures when stranded on the shore, especially in Cape Cod Bay, where they have gone in pursuit of food, the fishermen getting to the soaward of them and driving them ashore. They are likewise secured on the rocky coast of Scotland and other parts of northern Europe.

Aceorling to (apt. James Avery, of New Bedford, the sperm-whalers take them at all seasons of the year and throughout the Atlantic, but probably in greatest abundance on the west coast of African in $20^{\circ} \mathrm{W}$. longitude, and $15^{\circ}$ to $10^{\circ} \mathrm{N}$. latitude. The number caught anumally has greatly decreased in the last fifteen or twenty years. In 1881 the Elermor B. Comuell (aught 196, probably the greatest number taken in any one year by a single vessel. During the last three or four years the entire whaling fieet probably has not captured more than 20 or 25 amnually, yielding about 800 gallons of body oil and 50 gallons of hearl oil, the former worth $\$ 280$ and the latter $\$ 350$ at fisherman's prices.

The blark-fish are eaptured in much the same manner as very small sperm whales, and for cutting-in they are hove up on deck by means of lifting tackle. The blubber is nearly white, from 1 to 5 inches thick, and is removed from the carcass in longitudinal strips 8 or 10 inches widle. These strips are eut in horse-pieces and minced in the same manurer as already described for whale blubber, the blood being washer off the fat by dashing buckets of water over it. The minced blubber is then placed in the try-pots and cooked, and subsequently treated precisely as that of the right whale. The product of oil ranges from 5 to 120 gallons from each individual, averaging probably about 35 or 40 gallons. This is sometimes mixed with whale oil, although it has it greater value, selling usually for several cents per gallon more than that of the right whale.

The heat oil of the black-fish is taken from the melon or junk and the jaw-pans. The melon is a fatty mass on the top of the head, reaching from the spout hole to the end of the nose, and weighs ahout 25 pounds. This is washed free from blood, mineed, and plateed in the try-pot. The lower jaw is eut off, the jaw-pans ent out with a knife, minced, washed, and placed with the cleaned jaws and the melon in the try-pot. Some whalers cook the melon and the jaw materials separately, but the above is the usual method.

It is customary to cook the head matter of black-fish in fresh water. About 1.5 gallons of fresh water is placed in the pot, the fat is then 
added, and the whole hought to a gentle boil hy means of a sight fire. At this point a little overheating will effect great injury. When the cooking is completed the pot is allowed to cool and the following morning the oil is skimmed off. The product of hear oil from individual black-fish ranges from three-fourths of a gallon to 3 gallons, averaging probably about 2 gallons. At ordinary temperatures the blubber oil and the head oil of black-fish are much alike in their appearance, thus furnishing great temptation to the fishermen to mix a little of the cheap product with that of greater value, resulting in much vexation and loss to the refiner, as it is only in the process of refinement that the adulteration is revealed.

In addition to the black-fish secured by the syerm-whalers, larege numbers have been captured on the shores of Cape cor, where they are attracted by squid on which they feecl. The animals are surrounded by boats and driven like cattle to the beaches, and are there strander in eudeavoring to escapes. They are lanced to death and when the ticle falls the blubber and the oil-produciug head matter are stripped off and enveyed to tiry-works on the shore, where the oil is extracted in much the same mammer as alpearly drecribed for the vessel fishery.

The greatest eatch of black-fish on cape coul was macle in 18rt. On November 17 of that year 1,500 were killed at Blackfish Creak, South Wellfleet, where they had been driven ashore. About a month iater 500 more were slain in a great round-ny) in the bay. Since that time very few have been securech in the bay, nor have they been seen at sea in any such numbers as previous to the slaughter above noted.

The oil from the blubber of porpoise and of black-fish is refined in precisely the same mamner as whale oil, but the process of treatment applied to the head oils is far more complicated. These are very limpid, of an unusually low weather-test, amb have little corrosive effect on metallic surfaces, making them when refined superior for lubricating such delicate mechanisms as watches, chronometers, typewriters, etc. Practically all of these oils secrured in the American fisheries are refined at New Bedford and Provincetown, Mass., there being two refiners at the former place and one at the latter. $T^{r}$ are indebted principally to Mr. William F. Nye and to Mr. Joseph hi. Nye, of New Bedford, for the subjoined notes relative to the methods of refining.

In the preparation of watch and chronometer oils much depends upon the freshness of the fat at the time the oil is rendered and the freedom of the material from adulterants. Fresh substance produces much better oil than that which has partly decomposed, the product being sweeter and less rancid. No choice seems to exist between the porpoise-jaw oil ame the have-fish-hear oil, hoth ploducing refined articles of equal merit; but that of the black-fish seems to be the favorite hy a slight margin among the refiners, owing to its having more body, and possibly also to its greater abundance. A peculiarity of these oils is that they improve with age, differing in 
this particular from blubber oils. This is accounted for by the alternate gathering and emission of moisture upon exposure to changes of temperature, and by this and ofher treatment they become clear and brilliant, in conseguence of which they are seldom used within less than a year or two after they are obtained.

() nereipt of the oil at the factory the first step in the process of refining is to gently heat it 10 complete the process of cooking begum by the fishermen. The oil is then placed in tanks or casks to await the process of grading, and often two years may elapse ere the trained and skillful eye of the refiner can determine to what class it helongs. It is almost impossible to describe the extremely delicate variations in color, texture, odor, and flavor which enter into this grading. The cham is made that there are not half a dozen men in the world who have had the training and experience necessary to separate these delicate oils into their proper elasses, and yet a very large part of the reliability of watch and chronometer lubricants lies in the gradation under the almost instinctive skill of the refiner.

\section{According to Mr. Joseph K. Nye:}

After two years or more of rest, the oil has got to a condition where its snrplus oxyens have united with whatever animal or loose organic matter may have been floating in microscopic particles within it, and they are easily removed by the ordinary strainers of an oil factory. But something is still left in the oil Which is very sensible to the high or low range of temperature, and to remove this recuires its subjection, while spread out in thin layers, to a temperature far below zero. No further change in its construction can be made except at this very low temperature, nor must it be cooled too rapidly. When properly done the process is one most interesting to watch. All through its liquic amber little flecks of translucent material appear, joining and rejoining like frost on a window patne into most heautiful forms, resembling a miniature forest whose foliage is white. By means of a certain fine and close-grained fabric these particles at this juncture are filtered out: and strange to say, this residuum, once a portion of a brilliant, almost colorless fluid, never even at normal temperature becomes anything but a slimy mass, resembling poor lard.

In order to get this low temperature, one of the New Bedford refiners has established a chilling plant at St. Albans, Ti., where longcontinued cold can be depended upon.

To be thoroughly satisfactory the refined oil must be of uniform quality, (ntirely devoid of acidulous properties, absolutely gumless, withstand the rigors of the coldest climate without congealing, and maintain its borly or stability in a high temperature. This is the most delicate and highly refined lubricant known, and some has been proklucer for which a temperature of $-50^{\circ} \mathrm{F}$. has been claimed. While all watch-oil user's do not prefer colorless fluid, the average customer demancls an oil almost if not absolutely colorless and of crystal clearness. Much of the product is sold for repairer's' use in wooden boxes containing 1 dozen half-ounce bottles, each bottle inclosed in a small pasteboard box. The remainder, in tin cans having capacity for 1 pint, 1 quart, or of larger capacity, goes to the manufacturers of watches, clocks, chronometers, typewriters, etc. 


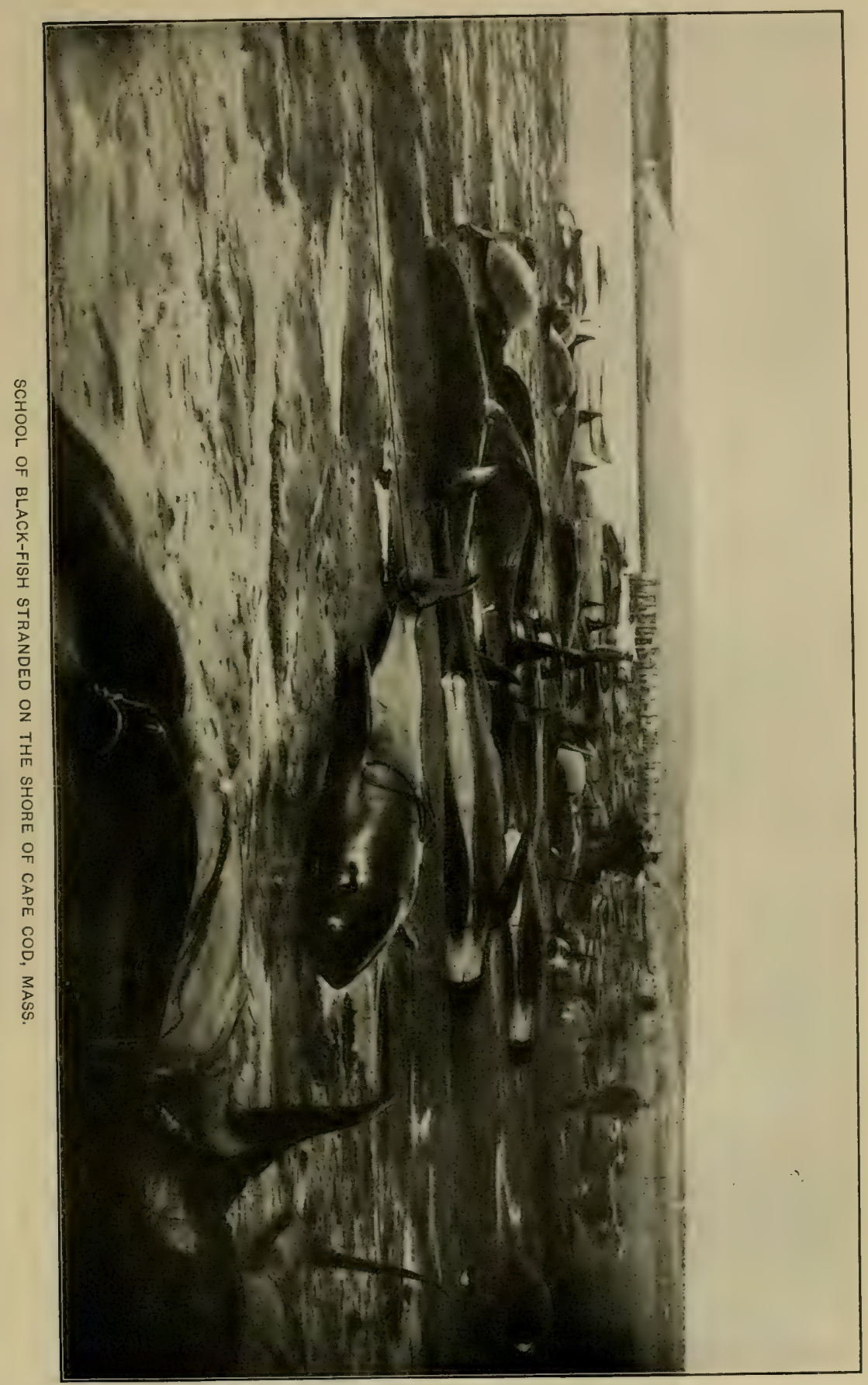



OILS FROM SEALS, WALRUS, ETC.

The blubber or fat lying between the skin and the musculat tisisues of the various members of the Pimipedin yields oil of much impurtance for technical purposes. The principal varieties on the market are from the common seals or hair-seals of the North Atantic, the walrus, the sea-elephant, and the sea-lions. Each of these will he discussed separately.

\section{SEAL OILS.}

Seals are found in various northern waters and especially of the

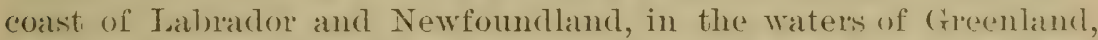
the Aretic Ocean north of Europe, in Caspian Fea, along the Tovil Scotian and Now England coasts, in the Northern Pacific, and to at much less extent in the Antaretic seas. The principal fisheries ane in the Aretic and North Atlantic oceans, especially of the coasts of Newfoundland, Greenland, and Northern Europe. The Caspian Sian also affords an important seal fishery.

The blubber of sals ranges in thickness from 1 to :3 inches, accorting to thr spereses, acer, and condition of the animals. It is removed from the pelt: ustally as soon as the latter are landed. If the weather is warm, (onsiclerable oil of prime quality flows from thr bluther during the process of separating it from the pelt, and provision is mate for this free oil to flow into suitable receptacles.

'The oil may be at once extracted, or the blubber may be stored for a more convenient season, especially if the weather he cold, as it is much easier to extract the oil during warm weather. If the hlubber is storect, it should be in well-ventilated apartments, so alranged that the vil folcerl out by compression and wamtl may lun inio suitable reservoirs. In the best-arranged storage rooms the reservoirs are oak-wood caskis, lined with lead in some instances, with ("apareity for a thousand or more gallons. These are placed at intervals in the floor, which is so inclined as to cause the oil to flow into the reeceptacle. The oil which flows under these rircumstances is usually clear, sweet, and of prime quality.

There are serral methods of extracting the bulk of the oil from the blubber, the one adopted depending to some extent on the proposed usc of the product and also on the amount of capital availahle for curtument and the quantity of blubber to be handled. The methors maty be divided into three principal classes, viz, (1) by maceration exposed to sular heat, (2) by cooking in open kettles, and (3) hy the application of steam.

The simplest method of extracting the oil is by exposing the minced blubber in a mass to the weather. The blubber is heaped up in large tanks and-when the temperature is suitable-clear, pale oil flows from the mass. As putrefaction adrances and the cellular texture is destroyed, the mass yields oil of a reddish yellow and then a dark Jorown color, with somerhat clisagreeable odor and flavor, owing to the 


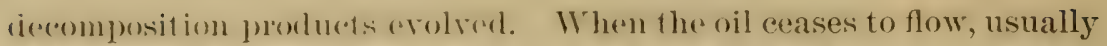
at the (and of 1 wo or three months, tho mass of fat is boilex in water with the fleshy of fall-lath pertions. During this hoiling the oil rises to the surfareat is skimmerl off. The resirlue is evaporated by posstureand alying, and is used for fertilizer. This was formerly the usual methor employeel in rendering seal oil in Newfoundland, but during the last 1 wenty-tive or thity years the steam process has been generally adopted.

In tratting a small yuantity of hubber for extraction of the oil it is usually more comvenient to minces it finely and cook it in a kette over a fire. The oil rises to the surface and is skimmed off and placed in casks ol" wher suitahle recoptacles. This is the mothor commonly employed by the shore hunters whose catch is small.

At the large sealing ports, as st. .Johns, Tönsberg, Dundee, Astrakham, chr., the oil is usually rentered hy means of steam. The mincerl blubluer is exposed to the action of steam in large inclosed tanks. The oil flowing therefrom passes through pipes into large reservoirs, of which there are usually three or more, the overflow from the first passing into the second, and the overflow from the second into the thirt. This furnishes the first quality of stram-refined oil. By pressing the steamed blubber, a second quality of dark-hrown oil is obtained.

The steam process of rendering has the arlvantage of rapidity in operation, also the oil is free from disagreeable odor and is of superior burning qualities. However, for uso in mines the sum-extracted oil is preferred, especially that of young seals, owing to its greater freedom from smoke, the orlor being of little consequence to miners. According to Mr. Carrol," oil from old seals is more smoky than that from young ones; it is also of greater specific gravity, and when the blubber of both are rendered together, the roung seal oil comes out first.

Although the catch of seals in the Newfoundland fishery in 1901 was almost as large as in 1900 , being 345,380 in 1901 , as compared with $35: 3,276$ in 1900 , the yield of oil was about 120,000 wallons less, representing a difference in value of about $\$ 50,0(0)$. This was principally becanse the average weight of the seals was small, owing to the fact that in 1901 the seals whelped some days later than in 1900, and furthermore, they were taken two or three days earlier than usual, the absence of pack ice enabling the ressels to reach them promptly after leaving harbor. In 1900 the average weight of the seal pelts was about 46 pounds, whereas in 1901 it was but 38 pounds. The young seals gain daily two or three pounds in weight of blubber, and if the ressels hat been three or four days later in reaching the herds, the yield of oil in the Newfoundland fishery in 1901 would probably have been approximately the same as in 1900.

The decadence of the seal-oil industry, especially in the waters morth of Europe, has heen gradual but certain, owing to the introduc-

\footnotetext{
uThe seal and herring fisheries of Newfoundland, by Michael Carrol, Montreal, 18\%3, p. 30.
} 
tion and adoption of cheaper substitutes for the relatively high-priced seal oil. Every year shows a decrease in the number of ressels employed in the fishery, and when a ressel is lost or sold it is rarely replaced. Comparatirely little seal oil is imported into this country, the quantity in some year's amounting to less than 1,000 barrels. The price in bond approximates 45 cents per gallon. The Newfoundland oils are marketed principally in St. Johns, Glasgow, London, and Leith; those from the waters north of Europe, at Dundee, Copenhagen, Ilamburg, and Archangel, and that from the Crispian seal fisheries at Astrakhan.

Seal oils vary in specific gravity from 0.915 to $\left(0.930\right.$ at $59^{\circ} \mathrm{F}$. According to Brannt, they are composed principally of glycericles of physetoleic acid, of palmitic, stearic, and a small quantity of oleic acid and traces of butyric acid, valerianic acid, etc. They show a slight acid reaction when fresh, the acidity increasing with age. Instead of the albuminous substances present in regetable oils, the seal oils contain a small quantity of glue which ean be precipitated with tamnin and metallic salts. They are very slightly soluble in alcohol, and require almost an equal volume for solution in ether. Mixtures of equal volumes of nitrie and sulphuric acids produce a reddish color, quickly changing to brown. The adulteration of seal oils is detected principally by the incomplete saponification if resin oil be the adulterant, and by the degree of solubility in alcohol if other blubber oils are employed.

In addition to the pure oils there are several well-known compound seal oils on the markets, the hest known heing the "three crowns." Greenland "three crowns" is a mixture of several varieties of bluhber oil, chiefly seal oil, or rather' seal-oil foots, and small quintities of whate and walrus, combined with oil from shark livers, the fluidity and low specific gravity of the shark oil imparting the special qualities to this compound. Swedish "three crowns" oil is a compound of various seal oils with herring oil.

The principal use for seal oil is for burning in miners' lamps, and it is also employed in currying and to a very small extent for miscellaneous purposes, especially fiber-dressing. About 2,500 tarrels are used amnually as an illuminant in the light-houses in the British North American provinces. Owing to its sluggish nature it is usually improved by the addition of mineral colza. An excellent miners' lamp oil is said to be composed of seal oil, 40 per cent; whale oil, 25 per cent; lardine $(0.980), 10$ per cent, and mineral colza, 25 per cent.

\section{SEA-ELEPHANT OIL.}

The sea-elephant or elephant-seal has furnished a large quantity of oil to the American markets during the last eighty years. The whalers operating in the extreme South Atlantic, and also the fur-sealers sailing to Falkland, South Georgia, and the coast of Patagonia, secured odd lots previous to $18(03$, but the first vessel specially fitted out for 
seruring this article appears to have been the ship Alliance, which saled from New Bedford in $18(13$ for Patagonia, and returned homo in 1804 with a full carege of oil. This was the pioneer of a latge mimber of vessols satiling to the Patagonian coast for sea-clephant oil. That (o) ste serms to have heen abandoned about 1820 for the South shetlind Islands, which for seventeen years furnished many cargoes to the fur-scalers sitiling from stonington. Since $18: 37$ Desolation or Krer?urelen Island has furnished the great bulk of the sea-elephant oil. II'arrl Island hats furnished many cargoes since 185̄, but on aceount of 1 he (xposed situation of that island vessels do not usually gro there whrll a (arrog is obtainable elsewhere. South Goorgia, south Shetlankls, and the Patagonian coast also have many sea-elephants and are oc(asionally visited by the hunters, but the great bulk of the eateh has been obtained at Desolation Island.

Althomgh the laking of sea-elephant oil originated with tho Nanturkef whalers, it has been peculiarly a New London industry since 1s:-1), the neighboring ports of Stonington and Mystic furnishing a number of vessels during certain seasons. From 1820 until the pres('nt time $3 t p^{2}$ cent of all the voyages have been made by ressels from these three ports, and s() per cent have been made by the Now Lomklon ressels. The fleet was largest in 1858 and 1859,18 vessels, with an agregate tonnage of $4,5: 27$ tons, being employed in 155.5 and 20 vessels, with 4,461 tons measurement, in 1859 .

The last vessol to return with a cargo was the brig Leonom, which arrivel in 1902 with 2,900 barrels of oil and a quantity of hicles. In 1!)(1) the sehooner Robert S. Graham brought in 2,600 barrels of oil and fo hides, the oil selling at 38 cents per gallon and the hides at s. each. In 1s!s the bark Suctlow, of Boston, returner with 2,000 barrels of oil, the product of 1,0 , 0 sea-elephants secured during the three months of the summer of 1897-98.

Acrording to Capt. James W. Budington, of Groton, Comn., to whom we are indebted for most of the subjoined data relative to methods of captureand of oil-rendering, sea-elephant blubber is somewhat whiter than whale blubber, and ranges in thickness from 1 to 8 inches, areording to the size and condition of the individual. It is thickest on the males, (specially the "Mareh bulls," from the neck of which $1($ )-inch blubler hats been secured. On the cows the thickness is from 2 to 3 inches and on the pups it is much less.

ILuch variation exists in the yield of oil from sea-elephants. The Guantity socured from the March bulls taken shortly after they land is very latre, amounting sometimes to 220 gallons from a single individual. (Only a small number of this variety is secured. The Novenbre bulls yield from 100 to 120 gallons each early in the season, but after remaining on the shore for months, abstaining from food, they hreome ematiated, and yield scarcely more than 30 gallons. The proulucet from lomales and pups is much smaller, some of the pups yielding only $t$ or it anllons, especially when the season is well advanced, thus 
greatly reducing the average take, which probably does not exceral 12 or 15 gallons to each individual throughout the season. The cargo of 2,000 barrels secured by the bark Swullou in 1898 represented an average yield of 15.75 gallons per individual. Another eargo of barrels, secured late in the season when the animals were in poor condition, represented the capture of 2,000 individuals.

'The hunters endeavor to arrive at the islands as soon as the seaelephants eome ashore, usually the early part of November. The animals are found in herds or pods varying in number from ?() to :30) or more each, the favorite resort apparently being the numerous nud puddles. The largest and fattest are selected for killing, females and pups heing unmolested if a sufficient number of large bulls is obtainable. The bulls are sometimes of enormous size, frequently 16 feet or more in length and 12 feet in circumference. 'The females are very much smaller, probably one-third the size of the bulls, but generally they are fatter for their size and their blubber is somewhat more yellowish. A number of seals of various species, especially the leopartseal, are frequently met with and are driven out and slaughtered when sea-elephants are scarce; otherwise they are not molesterl, as they are not nearly so fat as the sea-elephants. Rifles and lances are the weapons commonly employed in the slaughter.

After killing a sufficient number the skin is roughly and quickly sotten out of the way and the blubber taken off in horse-pieces of suitable size for handling, say about 18 inches wide and 2 feet long, or less, this varying according to the thickness. The horse-pieces are strung on a pole and carried down to the shore, 15 or 20 making a good loal for two men. At the shore the piecos are strung on rafttails or ropes, 18 or 20 feet long, and towed to tho ship. The long immersion in the water soaks off the sand and blood and cleanses the blubber.

The oil is extracted in much the same manner as in the whale fishcry. The blubber is lifted on deck, ent into strips about 2 inches wide, and these are minced or partly ent through at intervals of about 1 inch and placed in try-pots, precisely as in the case of whale blubber. The cooking is only slight, much less than applied to the whale blubber, being continued for only about 15 minutes. The fuel consists of the dry serap, supplemented with wood procured on the islands. After cooking for about 10 or 15 minutes and dipping off all the oil on the surface, the scrap is placed in a receptacle and subjecterl to considerable pressure, in the manner customary in the right-whale fishery already described. The oil does not run as freely from the blubber as whale oil; especially is this the case with the fat of the pups, which is fine-grained and "milky." Occasionally the oil is tried out on shore in a manner similar to that aboard the vessel, the try-works being erected near a running stream wherein the blubber may be washed free from sand and blood.

The product from all the southern islands from 1803 to 1900, 
inclusive, amommled to upwarel of 242,000 barrels, or $7,(i+3,000$ gallons, worth $\$ 5,420,000$, apportioned as follows:

\begin{tabular}{|c|c|c|c|}
\hline $\begin{array}{c}\text { Decado ending } \\
\text { June } 30\end{array}$ & Barrels. & $\begin{array}{l}\text { Decade ending } \\
\text { June } 20-\end{array}$ & Barrels. \\
\hline $\begin{array}{l}1810 \ldots \\
18 \times 20 \\
1830 \\
1840 \\
18.00\end{array}$ & $\begin{array}{r}2,500 \\
9,000 \\
9,500 \\
23,000 \\
38,000\end{array}$ & $\begin{array}{l}1860 \ldots \ldots \\
1870 \ldots \\
1880 \ldots \\
1890 \\
1900 \ldots\end{array}$ & $\begin{array}{r}62,754 \\
48,783 \\
34,015 \\
8,150 \\
6,340\end{array}$ \\
\hline
\end{tabular}

This oil is chassed as whale oil and has been inclueded in the product of that aticle, as shown on page 204 , although it is usually sold for ; or $\frac{1}{2}$ (ents per gallon more than the latter. The process of refinement is precisely the same as in case of whale oil, the foots yielder amounting to 5 or (i per "ent of the original bulk. Its principal use has been in the dressing of morocco leather.

\section{WALRUS OIL.}

When the whalers entered the North Pacific, walrus were found in great numbers, but were not disturbed, owing to the abundance of cetaceans. At times when whales were not to be found and many walrus were met with, a number of these were killed and the blubber tried-out, and this practice extended with the increasing scarcity of whales. About 1863 the northern whalers began to make a business of taking wallus during the first part of each season, some ressels securing upward of 500 barrels. Mr. A. Howard Clarke estimated that, during the eleven years ending in 1880, 1,996,000 gallons of walrus oil were secured by the whaling fleet in the North Pacific, the value of which was about $\$ 1,000,000$. The hunt was earried on with much waste. It is stated that on one occasion 1,600 walrus were killed on a sand bar in onc day, and the whole number were washed into the sea by an unusually high tide and thus lost. Since 1880 the quantity secured has decreased, and at the present time not more than 100 walrus are obtained ammually by the entire North Pacific fleet, representing an oil product of less than 2,000 gallons.

The blubber of walrus averages 2 or 3 inches in thickness, and usually it is is not detached from the skin mintil after the removal of the latter from the carcass. In case the hide is to be saved for tanning, the pelt is placer on a flensing board or platform, skin-sicle down, and the hlubber is eut off in irregularly shaped horse-pieces of $10 \mathrm{or} 15$ pounds' weight each. During the height of the Pacific walrus fishery the hides were not used, and then the skin and blubber were removed from the animal in horse-pieces of convenient size, say about $10 \mathrm{by}$ 14 inches, and these were separated aboard the vessel.

'The horse-pieces are next prepared for the try-pots. They are placed on the mincing-horse and scored or minced precisely in the manner described in the treatment of whale blubber. The cooking must be 
slow, the pot being well sparled during the boiling to prevent the blubber from sticking and burning to the bottom or side.

'The individual yield of oil varies considerably, walrus being much fatter in some year's than in other's. But in general it is small in proportion to the size of the animal, an individual weighing 1,500 pounds yielding only as much blubber as a seal of 600 pounds. An old bull weighing 2,500 pounds might yield 1500 pounds of blubber, but it is seldom more than 450 pounds, and the average for the entire catch is probably not in excess of 200 pounds. Nor is the blubber as rich in oil as is that of the seal, 100 pounds of walrus fat yielding an average of 10 gallons of oil, whereas an equal weight of seal blubber yields about $11 \frac{1}{1}$ gallons. In 1869 the ship Progress secured 565 barrels of oil from 700 walrus, an average of 25.42 gallons cach: This was considered an extra good yield. One thousand walrus secured by the ship Onurard in $187+$ yielded 600 barrels of oil, and 2,000 taken by the Mercury in 1875 produced 1,100 barrels of oil. ${ }^{*}$

Walrus oil is usually of a yellowish color, with greater fluidity than seal oil, and has a specific gravity of 0.925 at $59^{\circ} \mathrm{F}$. according to Brannt. It is more difficult to refine than the oil of the right whale. Although classed roughly as "whale oil" in the United States, it is usually kept separate from the oil of the right whale and sold for 2 or :3 cents per gallon more than the latter. It is stater that the product in the fisheries north of Europe is generally mixed with and sold as seal oil.

OIL FROM SEA-LIONS AND FUR-SEALS.

The blubber of the sea-lion is from 1 to $t$ inches thick, and that on each inclividual yields from 6 to 20 gallons of oil. Thousands of barrels of this oil were formerly secured along the coast of California, but owing to the decrease in number of these animals, comparatively little is now prepared. It is somewhat inferior to sea-elephant or walrus oils, but much better than fur'seal oil.

A number of years ago when whale and seal oils were quoted above "dollar per gallon, there was some sale in this country for oil prepared from the blubber of the fur-seal; but owing to the small quantity available, the cost of production, and the technical inferiority of the product, there has been no market for it for many years. The blubber may average $1 \frac{1}{2}$ inches in thickness, varying according to the time the animal has been on shore. The oil is of a yellowish-brown color, gummy, and possesses an offensive odor. According to the terms of the lease of the fur-sealing rights on the Pribilof Islauds to the North American Commercial Company, the United States Government is entitled to receive 50 cents per gallon for all fur-seal oil produced there. This is in excess of the market value of the article, leaving nothing for the cost of production and transportation, and, needless to state, there is no revenue whatever from this item. 


\section{OIL FROM LIVERS OF COD AND RELATED SPECIES.}

\section{SOURCWS OF SUPPLY.}

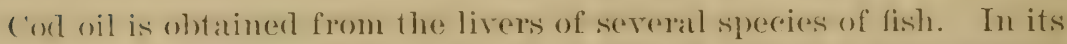

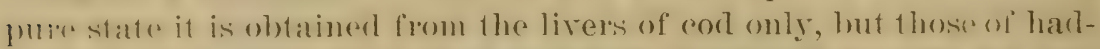

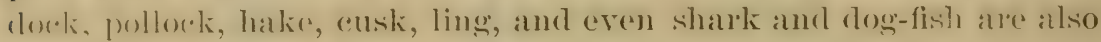

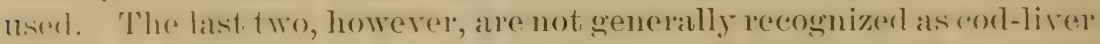
oil senrees, but ale userl mainly for purposes of adulteration. Th the

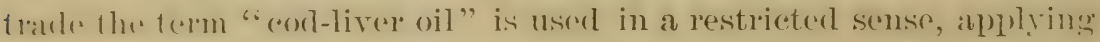
fo1 1 he hest quality of oil mate from choice fresh corl livers and intruded for molicinal purposes; all other oil manufactured from livers of cod

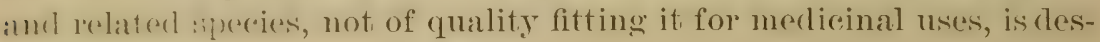
ignated as "cod oil" or "curriers oil."

c'or oil it of comparatively recent derelopment as an article of rommere. all hough it was used locally previous to the nineteenth eentury. (1) anount of the (atse with which whale and seal oils conld he secured, corl oil was not in ?heat demand for technical purposes until after the besimming of the nineternth eentury. There is nothing to inclioats that in the arly cort fisheries on the American coast the livers were ntilizal fo any great extent for oil-rentering, and the same is true of fhe (arly fisheries prosecuted in the seas north of Europe. The small d:mamel for modicinal and for technical purposes was loadily suppliod hy a lew fishermen of economical and industrious halsits, but their onf put bore omly a small proportion to the fotal quantity obtainalule. ('mupers usel a small quantity, and some was employerl on fruit trees for destroying insects and fungous growth.

Early in thr nineterenth century the production of eor oil became quite gemerall on the New England coast. Tho livers were placed in futts and promitted to decompose, and the oil exuding therefrom was dipperef of from tome to time. Not only was this done hy the fishermen who landed their catch ashore each night, but also by the "bankers" who carried butts and barrels for the purpose. As the tamming industries developert, the output of con wil incorased, and by

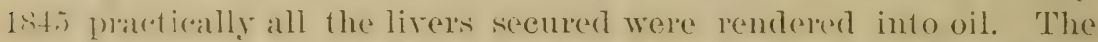
ontput, howerele, did not keep pace with the demand and during the

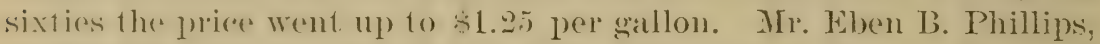
of twampirott, was ono of the pioneer dralers in this product and amassed a fortune in the business.

(riatlually other substances were introbluced as materials for dress-

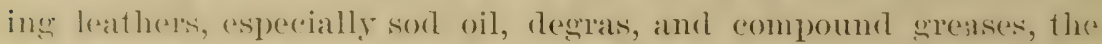
(-heapuless of whirh has ereatly affected the market for corl oil. The silistitution of matehine stuffing for hand stufing in leatheredressing and the interluction of chrome tammage have also rexhered the demanul. Inwerer, the market for merlicinal oil has constantly incoristel up to the present time. Is a result of these combined uses, the renclering of the livers into oil is almost coextensive in point 
of territory with the prosecution of the cod fisheries. The only excerption is in certain market fisheries where the men do not have time to handle the livers properly.

The market price of medicinal oil frequently falls so low that it pays the manufacturer better to prepare only low-gratle oil for leathercurrying, soap-making, and the like. The common oil is, of course, tumed out at much less enst than the white, orlorless, medicinal variety. The stearin, which is worth comparatively little and forms a considerable portion of the oil, need not he removed from the manufacturing grade. The use of the expensive refining plant required for medicinal oil is also obviated. And, finally, there is a very considerable saring in the cost of packing, as the ordinary oil is shipped in old petroleum barrels, while for the finer grade expensivenew casks or metallie drums have to be provided. For several seasons there was a large overproduction of low-grade medicinal oil, and three years ago it sold in New York as low as 50 cents per gallon. 'mrriers' oil does not often sell for less than 30 cents per gallon, and the demand for it is fairly constant.

The principal sources of cod-liver oil are the coast of North Americal from Labrador to Cape Cod, Norway, scotland, Iceland, the Paeifie coast of the United States, and, during reeent years, Japan. On account of its greater value, efforts are made on all these coasts to produce the light oil for medicinal purposes; but in most sections, on aceount of unfarorable natural conditions, only dark or low-grade oils are practicable. Medieinal oil is prepared chiefly on the coast of Norway and to a limited extent on the Massachusetts, Maine, Nova Scotia, and Newfoundland coasts.

Owing to the favorable conditions under which the corl fishery is there prosecuted, Norway ranks first among countries prolucing medieinal oil, the annual product amounting to about half a million gallons. The fishing-grounds are concentrated and situated very near the coast, so that the fish are landed in quantities within a few hours after capture and before decomposition of the livers has set in. Furthermore, the temperature during the fishing season is very low, being close to the freezing point, and this tends to retard putrefaction. In no other part of Europe are the conditions favorable for producing medicinal cod-liver oil. A large quantity of low-grade or curriers' oil is also produced in Norway, amounting probably to as much in bulk as the medicinal oil.

In Newfoundland much attention has been given to the production of medicinal oil, the manufacturers endeavoring to make it as near like the Norwegian product as possible. Freezing machines were introduced and a considerable quantity of white, odorless, and noncongealing oil was made. The general experience, however, was that the difference in market value of the medicinal and the trade oils was not sufficient to warrant the extra care and the ardditional 


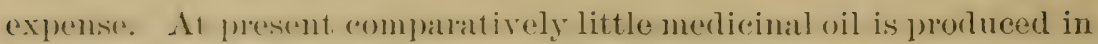
Nowfommlamel. 'The livers are mostly all converted into euriers' oil, resulting in an annual output of about 1,100,000 gallons.

The siluation in Nova seotia is metty much the same as in Newfommllamel, although murh less oil is produced, the ammual output probahly amounting to about $20,(0)$ gatlons of medicinal oil and 250,000 gallons of currier's' oil.

The bank fisheries of America are situated too far from the land to permit the use of the livers in making medicinal oil; but the shore fisheries during atutumn and winter, when the spawning fish visit the coast, funish gool material for that purpose, resulting in the preparation of alont 25,0) gallons each year. Mruch of this is of superior yuality, and unsurpasserl for color and pleasantmess of odor and taste. 'The livers taken in the bank fisheries are practically all used in preparing curriers' oil, the total annual product of which is about 450,000 gallons.

Considerable corl oil has been exported from .Tapan for medicinal purposes, but that received in this country has not found favor with the wholesale druggists and has usually been sold for currying. The first shipinent of 200 cases, made in 188.\%, sold at 35 cents per gallon. TVe have no data hearing on the cod-oil output in Japan, but with an ammual catch of $7,000,000$ fish it probably does not exceed 100,000 @allons.

The entire product of cod oil is estimated as follows: Norway, 1, 200 ,000 gallons; Newfoundland, 1,100,000 gallons; Dominion of Canada, 300,000 gallons; United States, 475,000 gallons; Japan and all other countries, 450,000 gallous, making a total of 3,525,000 gallons of all varieties of oil produced from the livers of cod and related species. Of this quantity about 650,000 gallons represent the output of medicinal oil, and the remaining $2,875,000$ gallons is currier's' oil.

\section{DESCRIPTION OF LIVERS AND THE RESULTING OILS.}

The following description of livers and the accomt of rendering them into oil are the results principally of an inquiry made by the writer on the New England coast in Oetober and November of 1901. Most of the oil factories were visited and many of the principal fishermen were interviewed. The witer is especially indebted in this connecetion to M[r. A. Wr. Dould and Messrs. Geolge J. Tarr \& Sons, of Gloucester, and to Messis. Geo. II. Leonard \& Co., Mr. John B. Baum, and Mr. F. F. Dimick, of Boston.

Normal cod livers in good condition are of a cream color, uniform texture, and very soft, so that the finger may be readily pushed quite through them. Iean livers are frequently found. These are tough and dark in color, the toughness and darkness increasing with the degree of leamness, the color finally reaching a dark brown hue. Lean livers furnish very inferior oil, as well as only a small quantity. A 
certain percentage of the livers are diseased. 'This comtition is usually' evidenced by a greenish color or by the presence of colorex spots, which increase in size and number as the diseaso advances until the entire organ is affected. Diseased livers are never used in the preparation of medicinal oil, but are freely utilized in making curriers' oil. The size of the livers varies considerably, but averages about 12 inches in length and $2 \frac{1}{2}$ inches in thickness in the center, the weight being somewhat over half a pound. Some livers weigh only 1.2 ounces each, and an instance is recorded by Dr. F. P. Moller of one taken in the Lofoden fishery which weighed 11 pounds, its length heing $4:$ inches and its greatest thickness $6 \frac{1}{2}$ inches.

Considerable difference exists in the size, shape, and general appearance of livers of the cod family. Cod livers are elongated, with the large end near the dorsal fins and the small end toward the tail. Iaddlock livers are much shorter than those of cod, and have little frills or scalloys on the edges, whereas those of cod are smooth. Haddock and pollock livers are of a cream color, similar to those of rod, while cusk and hake livers are of a light straw color. The livers of all Gadidce are usually mixed together by the fishermen, hut in the season when any particular species is abundant the livers of that variety are kept separate. On the New England coast of the United States cod livers predominate during the coldest months and pollock are taken mostly in October and November.

In the United States fisheries livers represent about $3 \frac{1}{2}$ per cent of the weight of the fish, and they yield abont 40 per cent of their weight in oil; consequently 100,000 pounds of fish yield about 180 gallons of oil. On an average, from January to June, 1,000 pounds, dressed weight, of cod yield about 1 bucket, or $2 \frac{1}{2}$ gallons, of livers, and during the latter half of the year the yield increases to 4 gallons per 1,000 pounds of dressed fish. A bucket of these livers yields 5 or 6 quarts of oil on an average throughout the year, except that in the spring the product is sometimes reduced to about 3 quarts to the bucket of livers. The yield of hake livers per 1,000 pounds of fish is somewhat larger than in case of cod, but the quantity of oil seeured from a bucket of livers is about the same. Haddock yield best from October to December, and during the spring and summer the result is small, sometimes not over $1 \frac{1}{2}$ quarts to the bucket. On account of the small yield and the conditions surrounding the haddock fishery, only about 15 per cent of the livers of that species are saved in the New England fisheries. At present pollock do not yield so much as cod, averaging about כّ quarts to the bucket of livers throughout the year; but previous to ten years ago on the New England coast they usually yielded 7 quarts of oil in the fall.

In the Lofoden fishery, according to the official returus, ordinarily 20 to 30 livers are required to produce 1 gallon of medicinal oil. During some seasons the livers are quite fat, and 8 to 12 are sufficient; 
but whon they are very lean, as was the case in $18,6 \%$ for instance, from :36 to : if are required for 1 gallon of oil. In that fishery the livers are fatter at the beginning than at the end of the season. They alratge about 55 pouncls to the 100 fish; hut duriug the years when they are unusually lean it is much less, as in 1883, when the average woight of 100 livens was only $12 \frac{1}{2}$ pounds. Usually at the Lofoden Istands 2.5$)$ fo 1,100 cod give 1 batrel of livers, and 2 barrels of livers yiolel 1 barrel of oil; but in 18s:) from 700 to 1,100 fish were requires for 1 harrel of livers, and $t$ or is barrels of those were necessaly for 1 barrel of oil. Asiste from the benefits areruing from the fatness of the livers, anything gained in quantity is always lost in quality in the preparation of medicinal oil.

While it is somewhat diffenlt to distinguish among the oils made from the livers of the various members of the cod family, yet ordinarily there are certain distinctive characteristics apparent to the skilled oil-refiner. Corl oil is of a greenish yellow eolor and usually has less pressings or foots than any of the others. IIake oil is almost white, but that made from hake taken on certain grounds has a pinkish color, which may be removed by filtration through a mineral earth. Pollock oil is distinguished by a slightly bitter taste and has a faint reddish cast. Its weather-test is rather lower than that of cod oil, especially when it has been slightly overcooked in the rontering.

Oil extracted from perfectly fresh corl livers is light and orlorless, and, owing to its extensive use in medicine, is known as medicinal cod oil or "cod-liver oil." Accorling to the extent of decomposition of the material before the extraction of the oil, the color ranges through all shatles of yellow and brown to very dark brown, this color being attributed to the recomposition of the hepatic tissues and fluids. These dark oils are of two general grades; one, the brown, which is inferior to the light-brown or medicinal oil, but is frequently used for such; and the other, the dark-brown or curriers' oil, is the poorest grade prepared, and is exclusively used for technical purposes. Probably it would be better to say that there are two principal varieties of oil, the medicinal and.the curriers', and that unusual market conditions may result sometimes in the employment of the poorest of the medicinal oil for technical uses or the best of the curriers' oil for officinal purposes.

The medieinal value of cod-liver oil was known centuries ago among the Laplaturler's in northern Europe, the descendants of the Norsemen in Iceland, and the Eskimos in Alaska. The use of the oil grarlually extender in Europe during the eighteenth century, being a popular home remety among many seacoast communities and used empirically by physicians. Percival and Bardsley in 1782 recommended its use in rases of gout and chronic rheumatism. In 1841, J. IIughes Bennett, of Erlinburgh, published a pamphlet on its medicinal qualities, strongly recommending it in many cases, aud this had much to 
do with the general introduction of the oil as a medicine in England and America. From that time to the present it has held a prominent place in the confidence of physicians, and is regarded as a remedy of the highest value in diseases which are marked by malnutrition, pulmonary tuberculosis furnishing the most frequent oceasion for its employment.

Few subjects connected with materia medica have provoked so much discussion as the comparative merits of the light and the dark grades of cod-liver oil. Formerly, the brown oil was considered superior in efficiency to the paler sorts, and was generally favored for medicinal purposes. In recent year's, however, chemists have claimed that analysis does not reveal any substance in the dark oil which would account for greater beneficial activity than the paler grades are supposed to possess. While many physicians yet recommend the brown oil, the drift of public opinion seems to favor the pale oil, and certainly it is more popular with the patients. A discussion of these rival claims is beyond the scope of this paper. For information on the subject reference is made to A. Gautier and L. Morgues' Les Alcaloides de l'Huite de Foie de Morue, Paris, 1890, and to F. P. Moller's Cod-Liver Oil and Chemistry, London, 1895.

\section{PREPARATION OF MEDICINAL OIL.}

On account of its greater value, it is generally desirable to convert, the livers into medicinal rather than curriers' oil. For this grade the liver's must be perfectly healthy and fresh, all diseased, lean, or slightly decomposed ones being rejected. On account of the necessity for having the material perfectly fresh, it is impracticable to manufacture good medicinal oil during the warm months, and even in cold weather the sooner the extraction of the oil is begun the better the grade secured. Furthermore, it is desirable that the livers should be from corl only, those from other species being excluded. This, however, is not the uniform practice, and the livers of haddock, hake, cusk, etc., are sometimes thrown in with those of cod. It does not appear that American manufacturers are any more prone to this adulteration than those of other countries. Possibly oil from other liver's may be equally as efficient as cod, yet until that fact is demonstrated beyond a doubt those should be rejected.

On the New England coast of the United States, the best medicinal oil is made from livers collected from the shore fishing boats, which land their catches almost daily, and thus deliver them in fresh condition. From May to October only a small amount of the best oil can be made, because of the scarcity of fish along shore during that season and the danger of the material putrefying before reaching the oil lactory. From October to May the shore fishermen carefully save the livers in clean barrels, and if landed within a day or two they are sold for making medicinal oil, but if softened or damaged in auy way they are used only for curriers' oil. 
Second only to the careful selection of the livers is the observance of perfect clamliness in the entire process of renrlering the oil. The livers are thoroughly cleansed from blood and other impurities by washing in several waters, and the gall sacs and attached membranes are removed. Throughout the entire process of expressing and refining the oil, all tanks, receptacles, and the like are kept free from putrefying texture. Some oil-renderers chop the livers into small pieces for the purpose of securing a greater quantity of oil, but this is by no means the general practice.

There are two general methods of cooking the livers, viz, (1) by wood or coal fire under a water bath, and (2) by the use of steam. The first-named is the oldest in use and is also the most economical where the quantity of material to be rendered is small. Tro metallic receptacles or pots are provided, one, in which the livers are placed, fitting loosely in the other, with 2 or 3 inches of space between, and the larger one set into a furnace so that a fire may be built beneath. The space between the two receptacles is filled with water during the process of cooking, and this is renewed as required. A fire is built in the furnace and the water brought to a boiling point, thus imparting a moderate heat to the contents of the pan. In order that the cooking may be expeditious the pan should be small, holding not over 50 or 60 gallons. Furthermore, it should be narrow, for greater ease in stirring and to minimize the oxygenizing of the oil. Owing to the cheapness of this apparatus it is quite popular with those who try-out only a small quantity of oil.

In the second method of cooking, steam-jacket kettles are used, the steam-chest being provided with a self-acting safety ralve by which the pressure can be controlled and regulated. WVithin the kettle there is usually a stirring apparatus operated by steam power. By means of this apparatus the cooking may be performed much more expeditiously than with the former one, as any desired temperature may be secured and uniformly maintained.

In order to prevent, so far as practicable, the formation of hydroxylated compounds, the alleged cause of the unpleasant eructations or gastric disturbance from which many persons suffer after taking the oil, there was introduced in Norway in 1892 an apparatus for its extraction without permitting oxidation to take place. This apparatus is so contrived that the air can be completely excluded from it during the whole operation, the process being conducted in a current of carbonic acid was from the moment the livers are placed in the apparatus until the oil is sealed up in the market receptacles.

Whatever process of cooking may bo adopted, it is desirable that the oil be forced out of the hepatic cells in a short space of time and by a moderate degree of heat only. The length of time usually allowed for cooking is from 2 to $3 \frac{1}{2}$ hours, and at no time should the temperature ('xeced $2(0)^{\circ} \mathrm{F}$. The duration of the eooking process is an 
item of great importance in the preparation of merlicinal oil, and on it is dependent in a large measure the quality of the product. In order to get the largest possible amount of oil, some producers rook the material. entirely too long, notwithstanding that beyond a certain point anything arained in quantity is at great sacrifice of quality. In producing a choice grade of oil, the livers must not be exposed to heat any louger than absolutely necessary.

The longer the cooking is continued, the greater the quantity of acids and decomposed albumen extracted from the hepatic tissues. These substances render the oil strong and mpalatable, and detract from its appearance. Further, the longer the livers are exposed to heat, the more oxygenized the oil becomes, making it irritative to the stomach and causing disagreeable eructations. For the production of the clearest and lightest medicinal oil, the livers should not be exposed to a greater heat than $160^{\circ} \mathrm{F}$, and that only for about 45 minutes. This, howerer, is not fuasible bucause the quantity of oil produced in that case would he too small to make the business profitable. The time must, therefore, be extencled as far as practicable without detracting too much from the ruality. But in order to produce a first-class medicinal oil, the length of the cooking should on no account exceed 21 or :3 hours, provided the capacity of the liverreceptacle does not exceed 50 gallons.

On completion of the cooking process, the mass of livers and oil is allowed to cool. The oil rises to the surface and is drawn off and filtered. The liver magma is subjected to pressure and yields a quantity of dark oil suitable only for curriers' use. The residuary mass of hepatic tissues is dried and used for fertilizing purposes. Its market value in Gloucester and Buston was formerly so or ss per ton, but at present it is only about $\$ 3$ per ton.

Filtering the medicinal oil is accomplished by rumning it though a box fitted with sereral straining frames covered with cloth of successive rlegrees of fineness and with a tap at the bottom through which the oil can be drawn. Or the filter may consist of one or two light canvas bags fitted inside of a white moleskin bag with the smooth side out. But in filtering the dark oil, it is better to rum it through charcoal.

In the process of refining, the medicinal oil is placed in small receptacles, as 5̃-gallon cans, and refrigerated either naturally in cold weather or by means of ice and salt, as already describerl in the process of refining sperm oil. When thoroughly chilled and gramulaterl the congealed oil is compressed through cotton or canvas bags holding about 4 gallous each, for the purpose of extracting the foots, white pressings, or stearin. Two or three bags are placed regularly upon a substantial woorlen platform or table provicled with groores for conducting the oulfowing oil to a receiving tank. On this low of bags there is laid at thin iron plate or slat, then another layer of 


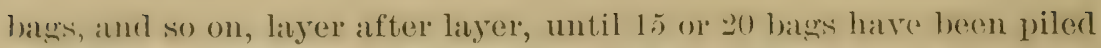
11). Heary pressure is then applied and continued 10 or le hours, when practically all the oil drains from the bags, loaving behind an uncluous mass of the consistency of tallow of butter, (omplosed of neally pure stearin, with a small quantity of débris and fibers. The guantity of steatrin remored depends on the temperature at which the congeraled oil is pressed. At the usmal temperature of $28^{\circ}$ to $30^{\circ}$

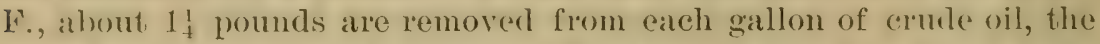

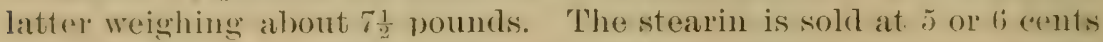
per poumd and is used by soap-and candle-makes's and as a tallow substitute in leather-dressing.

Merlicinal cod-liver oil should be exposed to the air as little as possible during the whole process of extraction, filtering, and pressing; and as soon as the last operation is completed, it should be placed in shipping parkages and stored in a cool place until marketed. This oil has a greenish tint, is almost hasteless and odorless. For the purpose of making the oil lighter in color, it is sometimes bleacher by exposing it in a thin layer to the sun's rays for an hour or more. Bleatching medicinal oil is an objectionable proeess, resulting in no particular benefit, and, on the contrary, is productire of much harm when long continued.

The style of the package in which medicinal oil is placed is of much importance. Since cod oil readily acquires the flavor of wood and becomes disiolored thereby, glass or metal receptacles are prefereecl. T'in is much the best material when glass is not user. The Nolwegrians use tin-lined barrels. When wooden barrels are employed, white oak is preferable to other varieties.

I) ring recent years many manufacturing pharmacists have prepared corl-liver oil in such a manner as to overeome the disagreeable flavol and the even more objectionable gastric disturbance which so freduently follows its use. These products are mostly in the form of cmulsions, gelatinous capsules, with sirups, creams, jellies, cotr.

Furthermore, some pharmacists remove the so-called "active principles" in cod-liver oil, the oil itself being subsequently used for technical purposes. These "active principles" are extracted by means of an alcoholic menstruum, then concentrated by evalporation and dissolved in wine. They are placed on the market under various proprictay names. In some factories the fresh livers, rather than the oil, aro used in manufacturing the "active principles," since the latter are alleged to occur in far greater abundance in the liver tissues than in the oil. According to an aceount given by the proprietor of one of these prepatrations, the livers are thoroughly minced in a steam-power (ohopping-machine and macerated for several days in large stiming matchines of spercial elesign, a menstrum being employed consisting of diluted alcohol containing a small quantity of citric acid. 'The extract is then drawn off and concentrated in vacuo at a temperature of $10^{\circ} \mathrm{F}$. When the liquid is reduced to about the consistency or 
extract of beef, it is remover from the vacuum pan, assayed for alkaloidal contents, and then dissolved in wine in proper proportion to represent the "active principles" contained in one-fourth its bulk of cod-liver oil.

Only about 10 per cent of the cod-liver oil consumed in this country is produced in the American fisheries, the great bulk of it being imported from Norway. As already shown, the product of medicinal oil in the United States fisheries is only about 25,000 gallons each year, whereas the imports usually exceed 200,000 gallons annually, and in some years exceed 500,000 gallons.

The following summary, showing the total quantity and value of cod-liver oil imported for consumption into the United States during a series of years, is compiled from the United States customs returns:

Statement of the quantity and value of cod-liver oil imported into the United States during a series of years.

\begin{tabular}{|c|c|c|c|c|c|c|c|}
\hline $\begin{array}{l}\text { Year ending } \\
\text { June } 30-\end{array}$ & Gallons. & Values. & $\begin{array}{l}\text { Average } \\
\text { value per } \\
\text { gallon. }\end{array}$ & $\begin{array}{l}\text { Yaar ending } \\
\text { June } 30\end{array}$ & Gallons. & Values. & $\begin{array}{l}\text { Average } \\
\text { value por } \\
\text { gallon. }\end{array}$ \\
\hline $\begin{array}{l}1880 \\
1881 \\
1888 \\
1883 \\
1884 \\
1886 \\
1887 \\
1888 \\
1889 \\
1890\end{array}$ & $\begin{array}{l}315,910 \\
516,657 \\
302,137 \\
218,716 \\
412,135 \\
221,050 \\
115,454 \\
130,296 \\
165,633 \\
287,183 \\
267,555\end{array}$ & $\begin{array}{r}\$ 15 \%, 441 \\
236,763 \\
162,563 \\
159,271 \\
275,078 \\
153,945 \\
67,65 \% \\
69,326 \\
78,233 \\
81,589 \\
86,476\end{array}$ & $\begin{array}{l}\$ 0.483 \\
.459 \\
.538 \\
.733 \\
.667 \\
.696 \\
.586 \\
.532 \\
.472 \\
.284 \\
.323\end{array}$ & $\begin{array}{l}1891 \\
1892 \\
1893 \\
1895 \\
1896 \\
1898 \\
1899 \\
1900 \\
1901\end{array}$ & $\begin{array}{l}248,894 \\
202,959 \\
190,432 \\
209,865 \\
207,145 \\
179,660 \\
179,677 \\
201,582 \\
233,176 \\
276,940 \\
235,749\end{array}$ & $\begin{array}{r}908,865 \\
115,577 \\
99,709 \\
99,318 \\
131,804 \\
203,588 \\
170,610 \\
116,913 \\
127,074 \\
136,666 \\
137,715\end{array}$ & $\begin{array}{r}\$ 0.397 \\
.569 \\
.524 \\
.473 \\
.636 \\
1.133 \\
.961 \\
.582 \\
.545 \\
.494 \\
.584\end{array}$ \\
\hline
\end{tabular}

\section{PREPARATION OF COD OIL FOR TECHNICAL PURPOSES.}

The methods of extracting cod oil for currying and other technical purposes does not differ essentially from the extraction of medicinal oil, the principal difference being the use of all livers secured, the absence of extreme cleanliuess, and the greater putrefaction or the more extensive cooking of the material. Considerable common oil is also expressed from the livers cooked for medicinal oil after the latter has been dipped or skimmed off.

The original method of extracting cod oil, and the most common one at the present time, is by putrefaction. In the Grand and the Western banks fisheries, during the process of dressing the fish, the livers are collected and placed in liver-butts. These butts are characteristic of vessels engaged in a salt-fish trip; in the market fishery for cor, haddlock, etc., their place is taken by upright barrels or gurry kids. There are two liver-butts on each vessel; they consist of large casks, with a capacity for about 150 gallons each, mounted horizontally on skids immediately in front of the house and lashed securely to the deck. On the top, in the bilge of each cask, there is a large square opening, covered with a piece of tarpaulin securely fastened at one 
end, through which the livers are dropped into the eask. As the oil cells in the livers are broken by decomposition and by their constant churning with the rolling of the vessel, the oil rises to the surface, and is bailer off from time to time to make room for fresh livers. The oil dipperl or hailed off, known as "sun-tried oil" or "top dippings," is places in barrels, while the refuse blubber remains until the vessel reaches port, when it is boiled to extract the remaining oil.

The "sun-tried oil" represents probably 20 to 40 per cent of the total quantity of oil produced. It is superior to that rendered by cooking, being heavier hodied, and does not chill so quickly, the quantity of foots being much less. The oil first obtained from the butts is of a light yellow color, and formerly was used to some extent for medicinal purposes. As putrefaction advances, the color deepens to a brownish shade, and that extracted by cooking the decomposed livers ashore is very dark, with a greenish fluorescence in reflected light. In small quantities it shows a brown color, and therefore is known as brown oil. None of this oil is used for medicinal purposes, owing to its strong odor and flavor and the abundance of decomposed tissue contained in it. The market fishermen, who return to port every two or three weeks, save the livers and sell them to the oil-merchants at 25 or 30 cents per bucket of $2 \frac{1}{2}$ gallons each.

Of the several grades of cod oil used for technical purposes, the best is that made from livers taken in the Grand Banks fisheries; this is known as "Newfoundland cod oil" and sells for about 2 cents per gallon more than "domestic cod oil " made from liver's taken on Western and Georges Banks. "Straits oil" and "bank oil" were formerly well-known grades of cod oil, but these are now made entirely from menhaden. The low grades of cod oil are strained or filtered in the same way as the medieinal oil, 100 gallons yielding 15 or 20 pounds of foots, worth about 4 cents per pound.

Cod oil is used for currying mostly in New York, Pennsylrania, Ohio, Michigan, Illinois, and $\mathrm{W}$ isconsin, only about 20 per cent being used in New England. Some of the best quality is exported. Small quantities are also used for soap-making and in various compounds.

The following table (based upon the closing quotations each week for prime domestic oil, as contained in the New York trade journals) shows the Jowest and highest selling prices for cod oil for technical purposes in the New York market during each year from 1891 to 1902:

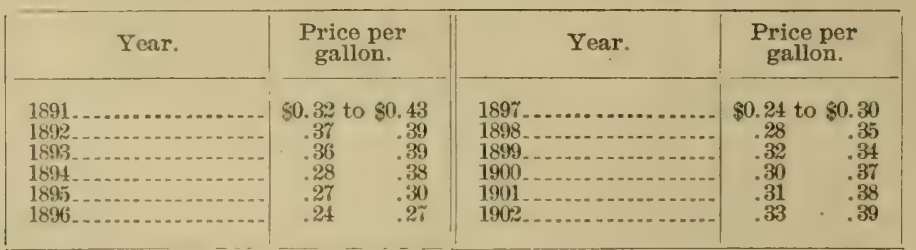




\section{OIL FROM LIVERS OF SHARKS AND RELATED SPECIES.}

The livers of various species of sharks and allied fish are suitable for oil-produetion, giving rise in some localities to important, fisheries. The principal species used are the sleeper shark, otherwise known as the nurse, ground, or gurry shark (Somniosuss), taken in northern waters from the Aretic seas southward to Massachusetts, Oregon, and France; the basking or bone shark (Cetorthimus), formerly quite numerous, but now taken to a less extent, north of Europe and on the coast of Peru, Australia, California, ete.; the oil shark (Galeorhinus), on the Pacific coast, especially in California, and the dog-fish (Squalus), distributed throughout both hemispheres. In aldition to these, nearly every species of shark yields livers suitable for oilrendering.

The sleeper shark appears to be the most important species so far as oil-making is concerned. This is a large fish, individuals ranging in length from 12 to 25 feet. The livers yield from 12 to 50 gallous of oil each when taken in the autumn, but in the spring and summer they are almost worthless for oil purposes. On the New England coast this species is much less numerous than formerly, but it is reported in abundance on the Pacific coast of the United States.

During the antumn the taking of the sleeper shark is a somewhat important branch of the minor Icelandic fisheries, and it is also taken by the Russians off the Kola Peninsula. The most important fishery, however, is off the coast of Norway, and especially between Lofoden Islands and Bear Island, in depths of from 150 to 200 fathoms of water. The Norwegians employ small vessels of 20 to 35 tons, carrying about six men each, the season beginning the first of Octoler and ending in February. The fish are taken by means of large, strong hooks baited with fish or salted seal blubber.

The basking shark, probably the largest of all sea fishes, has been taken very extensively for the oil contained in the livers, but owing to decrease of the species the quantity now secured is much reduced. This fish attains an enormous size, the prevailing length of fullygrown individuals being 30 to 35 feet. The liver is proportionally large, yielding ordinarily from 80 to 200 gallons of oil and occasionally as much as 400 gallons. Indeed, a yield of 600 gallons has been reported from a single individual, but this has not been satisfactorily established. This speeies differs from other sharks in not being voracious. Therefore it must be taken with harpoons rather than with bated hooks. There is said to have been quite an extensive fishery for it on the Massachusetts coast about the middle of the eighteenth century. According to Captain Atwood, writing in 1880, "Not more than half a dozen have been caught near Provincetown since 1810."

The basking shark is numerous on the coast of Peru and Ecuador, 
and its rapture gives employment to a large number of small vessels, manmerl by ti of is moll (ach. The American vessels fishing for humpback whales on that coast have occasionally engaged in its capture when whales were not in sight. Capt. George O. Baker, of New Budford, leports that on one occasion in two days' fishing he secured 125 batrels of shark oil while on the lookout for humplatek whales.

The method of taking this fish off the Peruvian coast, aceording to Captain Baker, is to approach it while it is lying motionless at the surface of the water and to fasten a harpoon in the top of the head

- forward of the eyes, so as to hold the head up and thus prevent the fish from going down or "sounding," and then the boat approaches and lances it until it is quite dead. It is taken alongside the vessel, a hole is cut in one side of the abdomen, a strap inserted on either side of the incision and the tail hoisted up so as to raise the body somewhat out of the water. A man then enters the abdominal cavity and with a knife cuts out the liver in pieces. These are passed up on deck, minced, as in the case of whale blubber, and placed in the try-pots. After a sufficient length of time the cooked liver-pieces are removed from the pot, placed in a canvas or hempen bag, suspended from aloft, and permitted to drain. Nothing but the oil is saved. $\Lambda$ considerable market for it exists in South America, where it is used principally as a body for paints for exterior surfaces. The price is usually $S$ or 10 cents per gallon more than that of humpback oil.

The basking shark is taken occasionally on the California coast, the individual yield of oil ther $\mathrm{everaging}$ about 125 gallons. The same species is also said to be taken in the waters of British India, being harpooned in great numbers by the fishermen of Karachi and other coastal districts.

The common dog-fish (Squalus) of the Atlantic coast and a similar species on the Pacific coast are the principal oil-yielding sharks in America. These fish range from 2 to 5 feet in length and from 5 to 15 pounds in weight. They are the great pest of fishermen, destroying nets, robbing fish from the trawls, and committing other depredations.

It does not appear that any important fisheries are organized especially for the capture of these fish, but many are taken incidentally in the shore and Georges cod fisheries, particularly during the spring, and the livers are extracted and thrown in the liver-butts along with those of other fish. The livers are generally of a bluish-gray color, shaped somewhat like those of cod or pollock and are rery brittle, breaking readily when lifted.

In Boston and Gloucester dog-fish livers are sold at the same rate as those of rod and related species-viz, 25 to 30 cents per bucket of $2 \frac{1}{2}$ gallons. The yield of oil during Angust, September, and October is about (; quarts per bucket, but at other seasons it is much smaller.

Because of the small quantity secured, this oil is rarely kept separate from cod oil for currying purposes, and it sells for about the same 
price per gallon. A distinctive characteristic is its strong odor when warm, resembling that of ammonia; but this may be remover by proper refining. It is estimated that from 10,000 to 15,000 gallons of dog-fish oil are prepared on the New England coast annually, nearly all of which is combined with and sold as cod oil for eurryiug purposes.

Captain Atwood writes: "

When I first began to go fishing, in 1810 to 1820 , the dog-fish fishery was considered one of the most valuable fisheries that we had around the shore. They anplpeared here in the spring and were very plenty, and would last a day or two and then all would be gone. Then yon wonld not see a dog-fish again all stmmer, but about the 10th or middle of September they came to us again, returning Sonth. They would stay into November, and during that time the fishermen would get-a man and a boy-all the way from 8,10 , to 15 barrels of oil. Twenty-five years ago we would occasionally see dog-fish in the summer. The last fifteen years they have been here all summer. During the war they were plenty all summer, and the livers sold for $\$ 1$ a bucket, and now they are worth but 20 or 25 cents.

On the coast of Oregon, Washington, and British ('olumbia, large numbers of dog-fish are taken for conversion of the livers into oil. which finds a ready sale, owing to the high cost of other oils on that coast. These fish are reported especially abundant in the vicinity of Queen Charlotte Island, in British Columbia, where they are captured by the Indians. The livers of 100 dog-fish yield 6 or 8 gallons of oil, and the rest of the carcass is utilized for fertilizer. Not only is there an abundance of this oil produced for local use, but also much for export. As long ago as 1876, about 60,000 gallons were exported from Victoria, at a valuation of 40 cents per gallon." The present amnual product, is said to exceed 200,000 gallons. New York dealers have received some good samples which indicate a very low weather-test, but owing to the duty and freight rates little has come on the Eastern market.

Dog-fish oil has been used on the Pacific coast in competition with other oils with most favorable results, being " equal, if not superior, to oil supplied to Her Majesty's ships by the service, both for lubricating and lighting purposes."c

Similar species of dog-fish are taken on the coasts of Norway, Chile, and elsewhere, the fisheries being confined to the summer months and the eatch seculed with nets as well as with hooks.

Along the Atlantic coast of the United States but little attention is given to the capture of sharks for economic purposes, notwithstanding the many species which oceur there in comparatively laige numbers. In several localities on the souther'n coast small fisheries are prosecuted during the winter months, for then the yield of oil is greatest. Among the species taken, other than those above mentioned, are the sand or yellow shark (Carcharias littoralis), which $1881, p .214$ of supplement No. 2 . 
attains a length of 5 feet, and yields from 1 to 2 gallons of oil; the leopard or tiger shatr, length from 10 to 25 feet, yielding 10 to 20 gatlons of oil: the mackerel shark, also known as porbeagle or blue shatk, measuring from 8 to 10 feet in length, and the liver yielding from 2 to 7 gallons of oil; the dusky shark (Carchurhimes obscurus), which attains a length of 10) feet; the hammer-headerl shark (Sphyjna

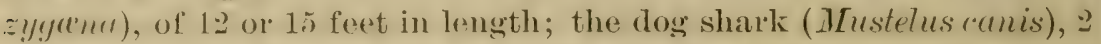
or' 3 foet in length; and the thresher shark (Alopius rulpes). Some of the latere sand and leopard sharks are diffeult to secure and their capture gives consiclerable trouble. They are taken usually by means of harpoons or stout hooks and lines. Wheu taken from a small boat at sea, immerliately after the fish has been secured it is lanced to death, the belly is ripped open with a knife, the boat canted, and the larese, slippery liver pulled over the side into the boat, and then the carcass is discarded. Many of the smaller sharks are captured with menhaten, in purse seines, and are utilized at the menhaden factories. (Owing to the dimage which they do to the twine, the fishermen prefer to not set the seines around sharks, but it is difficult to avoid taking a few of them with the menhaden. It is estimated that from $7,0(0)$ to $10,0(10)$ sharks are captured annually by the menhaden steamers, all of which are converted into oil and fertilizer.

On the Pacific coast of the Tnited States, especially in California, the oil shark (Galeorhimus) is utilized. It is \pm to 6 feet in length and weighs from $\left.t^{\prime}\right)$ to 70 pounds, the yield of oil from the livers varying from two-thirds of a gallon to 1 gallon each. The fish are taken by means of hooks and lines when they enter the laxgoons for reproductive purposes during the summer. The fins of this species are dried and sold for 1: or 15 cents per pound, the Chinese using them in soup-making. Other species of shark utilized on the Pacific coast are the shovel-nose shark, thresher shark, and the man-eater or white shark. 'The shovel-nose shark was taken extensively along the coast of II mulboldt County, Cal., from 185s to 1868, from 50 to 60 men being employed at times in the fishery. It is harpooned in deep water and taken hy means of hand lines in shallow water. This species measures from 6 to 10 feet in length, and the liver of each individual yields 3 to 7 gallows of oil.

There are several species of skates, rays, etc, occurring on the United states coasts which aro utilized to some extent for oil-production. Principal amomg these are the common skate (Raja erinacea), the prickly skate $(R$. eglanteria), the smooth or barn-door skate $(R$. lacis), the sting ray (Dasyatis centrura), the cow-nose ray (Rhinop)teru bonusus), etc. Many thousands of these are captured by the menhaten fishermen and ntilized at the factories for conversion into oil and wamo. Oil from the liver of the torpedo or cramp-fish (Tetronarcercidentulis), a lange species, which at times attains a weight of 200 poumds, is said to be valued by the fishermen in the treatment of cramp and rheumatism. 
Captain Atwood wrote in regard to the oil from the torpedo:

I used to go and look for them for their livers-for the oil. The oil is one of the best lamp oils that I ever saw. It has been used sometimes beneficially in cases of crainp. I got a gallon of oil from one liver. I do not know but I have seen a cramp-fish big enough to make three gallons of oil. $a$

The liver of the saw-fish (Pristis), numerous on the South Atlantic and Gulf coasts of the United States, yields from ( $\mathrm{j}$ to 18 gallons of oil. It is said that in British Guiana this oil is used for illumination and also for anointing the bodies of the inhabitants. The liver of the elephant-fish (Chimcera), which occurs in abundance on the California coast, is large and yields choice oil. This fish has a maximum length of 2 feet and weighs 6 or 7 pounds.

It appears from the above that the yield of oil from individual shark livers ranges from much less than 1 pint in case of the dog-fish and others to the 400 gallons procured from the basking shark. Other than the livers, the carcasses of sharks are slightly oleaginous, and are rarely ever utilized in oil-rendering, but they are of course useful for conversion into fertilizer. The method of extracting the oil from the livers is much the same in all cases. If they are large, they should first be cut in small pieces or minced, as is done with whale blubber. The pieces are then subjected to heat until the cells are thoroughly broken, when the oil is extracted by pressure or it is permitted to drain therefrom. In case the oil is to be used for medicinal purposes great cleanliness is observed, the livers being washed free from blood and the gall bladder removed. A quantity of water is placed in the kettle with the hepatic tissues and the whole boiled gently for an hour or two. On cooling, the oil floats on the surface and is dippert off and stored. It may be refined in precisely the same manner as cod oil.

According to Brannt, shark oils are distinguished as being the lightest of fixed oils, their specific gravities ranging from 0.870 to 0.880 at $59^{\circ} \mathrm{F}$., so that a mixture with blubber or other fish oils can at once be recognized by the higher specific gravity. 'They are pale yellow and clear, remain fluid at $21^{\circ} \mathrm{F}$. and contain very little stearin. They burn with a bright flame without carbonizing the wick. Brannt further states that they contain about the same constituents as cod-liver oil, but are richer in iodine. On account of their percentage of gall constituents the liver oils are readily distinguished from other fish oils.

Shark oils are largely used in tanneries, in steel-tempering, and in various compounds where it is desired to impart a low specific gravity. They are also valuable as a body for paints for out-of-door objects, as walls, fences, etc. In some localities certain kinds are used by medical practitioners, who consider them quite equal to cod-liver oil. In the drug stores of this country shark oil is occasionally found with a label suggestive of an oriental origin and recommending its use as an embrocation in numerous diseases. 


\section{MENHADEN OIL.}

In speaking of fish oil in a restricted sense along the Atlantic coast of the United states, roference is made renerally to that yielded by the menhaden (Brevortia tyramms), a member of the Clupeidce or herring family, known locally by a seore or more of names. This species oceurs from Maine to Texas, the principal fishing-grounds being the bays and sounds from Maine to North Carolina, with the addition of the 'lexas coast during the last two years.

'The extraction of menhaden oil differs from the preparation of other marine-animal oils in that the scrap or solid tissue remaining after the liquids have been removed is usually greater in value than the oil. Indeed, it was principally as a fertilizer that the menhaden was first utilized, the oil being extracted as an incidental product. Because of the greater value and importance of the scrap, the methods of manipulating the fish, extracting the oil, and the like are described in the second part of this report, relating to the preparation and utilization of fertilizers from fishery products. (See pp. 255-265.)

While small quantities of menhaden oil were prepared for domestic and local use previous to 1860 , there was comparatively little marketed previous to the civil war. The first lot on the New York market sold at 75 cents per gallon and, its use giving satisfaction, the market price quickly atranced to $\$ 1.40$ in 1865, the highest figure ever realized. For ten years the menhaden producers sold their crude oil within a range of 50 cents and $\$ 1$ per gallon, resulting in great profit. This led to a large increase in the number of factories, tho purchase of costly steamers and equipments, and a great overproduction.

The excess of production, a lack of cooperation amoug the factorymen, and competition with substitutes resulted in a gradual reduction of prices, until in the autumn of 1887 menhaden oil sold at 19 cents per gallon, which was much below the cost of manufacture. The necessity for protecting their invested capital led to concerted action among the producers and an attempt to bring about an agreemeni on prices and also a limitation of the fishing season. Many factories were closed and the vessels laid up, the owners preferring to keep them idle rather than to engage in unprofitable work.

The diminished extent of the output and a better understanding among the producers resulted in an improvement in prices, which finally reached 40 cents per gallon in the spring of 1893 . Then, owing to unfarorable conditions, prices began to decrease until in the fall of 1896 crude northern menhaden oil was sold at 18 cents per gallon, the lowest price ever reached. Since 1896 the business has been conducted with much less competition and with greater economy by reason of improved machinery and increased facilities, and as prices have been somewhat higher a fair profit has been derived from the business by those whose invested capital is not greatly in excess of the value of their respective plants. 


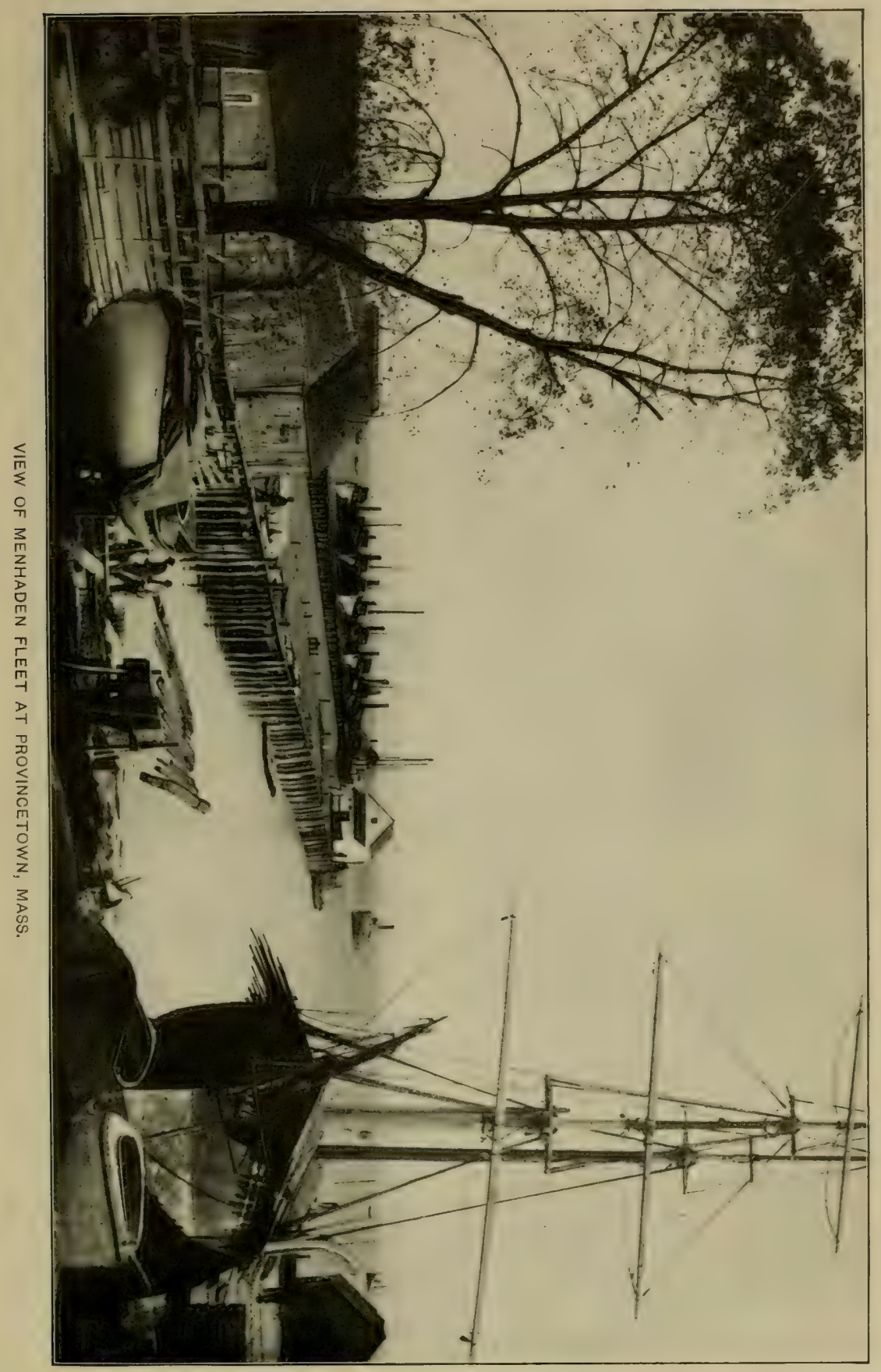



During the last thirty year's the product of menhaden oil has averaged about 2,000,000 gallons annually. The largest yield was in 1878, when 3,809,233 gallous were produced, and the smallest in 1881, when the reported product was only $1,266,549$ gallons. The following summary, compiled from the returns of the United States Menhaden Oil and Guano Association, shows the proluct for each year from 1873 to 1898, inclusive, and also the number of fish taken. For purposes of comparison, the average quantity of oil to the thousand fish in each year is also given.

Statement of the quantity of menhaden oil manufactured, the number of menhaden utilized, and the average quantity of oil to the thousand fish in each year from 1873 to 1898 , inclusive.

\begin{tabular}{|c|c|c|c|c|c|c|c|}
\hline Year. & Oil macle. & $\begin{array}{c}\text { Fish util- } \\
\text { ized. }\end{array}$ & $\begin{array}{l}\text { Quantity } \\
\text { of oil to } \\
1,000 \text { fish. }\end{array}$ & Yeal. & Oil made. & $\begin{array}{l}\text { Fish util- } \\
\text { ized. }\end{array}$ & $\begin{array}{l}\text { Quantity } \\
\text { of oil to } \\
1,000 \text { fish. }\end{array}$ \\
\hline $\begin{array}{l}1873 \ldots \ldots \\
1874 \ldots \ldots \\
1875 \ldots \ldots \\
1876 \ldots \ldots \\
1877 \ldots \ldots \\
1878 \ldots \ldots \\
1879 \\
1880 \ldots \ldots \\
1881 \ldots \ldots \\
1882 \ldots \ldots \\
1883 \ldots \ldots \\
1884 \ldots \ldots\end{array}$ & $\begin{array}{l}\text { Gallons. } \\
2,214,800 . \\
3,372,847 \\
2,681,482 \\
2,992,000 \\
2,426,589 \\
3,809,233 \\
2,258,901 \\
2,034,940 \\
1,266,549 \\
2,021,316 \\
2,166,320 \\
3,722,927 \\
2,346,319\end{array}$ & $\begin{array}{l}\text { Number. } \\
397,700,000 \\
492,878,000 \\
563,327,000 \\
512,450,000 \\
587,642,125 \\
767,779,250 \\
637,063,750 \\
776,875,000 \\
454,192,000 \\
346,638,555 \\
613,461,776 \\
858,592,691 \\
479,214,415\end{array}$ & $\begin{array}{r}\text { Gallons. } \\
5.57 \\
6.84 \\
4.76 \\
5.84 \\
4.13 \\
4.96 \\
3.37 \\
2.62 \\
2.79 \\
5.83 \\
3.55 \\
4.34 \\
4.89\end{array}$ & $\begin{array}{l}1886 \ldots \ldots \\
1887 \ldots \ldots \\
1888 \ldots \ldots \\
1889 \ldots \ldots \\
1890 \ldots \ldots \\
1891 \ldots \ldots \\
1892 \ldots \ldots \\
1893 \ldots \ldots \\
1894 \ldots \ldots \\
1895 \ldots \ldots \\
1896 \ldots \ldots \\
1898 \ldots \ldots \ldots\end{array}$ & $\begin{array}{l}\text { Gallons. } \\
1,805,544 \\
2,273,566 \\
2,051,128 \\
3,327,030 \\
2,939,217 \\
1,946,642 \\
1,329,644 \\
1,269,002 \\
1,999,506 \\
1,767,754 \\
1,741,530 \\
2,147,113 \\
2,450,000\end{array}$ & $\begin{array}{l}\text { Number. } \\
283,106,000 \\
333,564,800 \\
439,388,950 \\
555,319,800 \\
533,686,156 \\
355,138,873 \\
223,623,750 \\
366,406,625 \\
533,361,900 \\
461,747,000 \\
401,425,800 \\
584,302,930 \\
542,500,000\end{array}$ & $\begin{array}{r}\text { Gallons. } \\
\mathbf{6 . 3 8} \\
\mathbf{6 . 8 1} \\
\mathbf{4 . 6 7} \\
\mathbf{5 . 9 9} \\
\mathbf{5 . 5 1} \\
\mathbf{5} .48 \\
\mathbf{5 . 9 5} \\
\mathbf{3 . 4 7} \\
\mathbf{3 .} 75 \\
\mathbf{3} .83 \\
\mathbf{4 . 3 4} \\
\mathbf{3 . 6 8} \\
\mathbf{4 . 5 1}\end{array}$ \\
\hline
\end{tabular}

The following shows the lowest and highest prices quoted for crude northern menhaden oil in the New York market each year from 1863 to 1901, inclusive. These figures are based on the closing quotations publisher in the New York trade journals, especially the Oit, Puint and Drug Reporter, each successive week.

Statement of the range of prices for crude northern menhaden oil in the New York market from 1863 to 1902; inclusive.

\begin{tabular}{|c|c|c|c|c|c|}
\hline Year. & Lowest. & Highest. & Year. & Lowest. & Highest. \\
\hline $\begin{array}{l}1863 \\
1864 \\
18666 \\
1867 \\
1868 \\
1870 \\
1871 \\
1872 \\
1878 \\
1874 \\
1875 \\
1877 \\
1878 \\
1879 \\
1880 \\
1881 \\
1882\end{array}$ & $\begin{array}{r}\$ 0.75 \\
1.10 \\
.80 \\
.70 \\
.45 \\
.50 \\
.62 \\
.40_{2}^{2} \\
.35 \\
.36 \\
.32 \\
.35 \\
.30 \frac{1}{2} \\
.30 \\
.30 \\
.23 \\
.24 \\
.29 \\
.30 \\
.32\end{array}$ & $\begin{array}{c}\$ 1.00 \\
1.35 \\
1.40 \\
1.13 \frac{1}{2} \\
.70 \\
.95 \\
1.02 \\
.68 \\
.55 \\
.65 \\
.601 \\
.471 \\
.48 \frac{1}{2} \\
.50 \\
.46 \\
.45 \\
.35 \\
.43 \\
.391 \\
.42\end{array}$ & $\begin{array}{l}1883 \\
1884 \\
18856 \\
1887 \\
1888 \\
1889 \\
18901 \\
1892 \\
1893 \\
1894 \\
1895 \\
1896 \\
1898 \\
1899 \\
1900 \\
1901\end{array}$ & $\begin{array}{l}\$ 0.35 \\
.26 \\
.21 \\
.20 \\
.19 \\
.20 \\
.21 \\
.22 \\
.251 \\
.30 \\
.33 \\
.21 \\
.19 \\
.18 \\
.18 \\
.221 \\
.221 \\
.25 \\
.26 \\
.26\end{array}$ & $\begin{array}{r}80.48 \\
.473 \\
.30 \\
.26 \\
.21 \\
.32 \\
.32 \\
.30 \\
.30 \\
.38 \\
.40 \\
.33 \\
.25 \\
.23 \\
.25 \\
.24 \\
.27 \\
.27 \\
.30 \\
.29\end{array}$ \\
\hline
\end{tabular}

Menhaden oil varies in color from clear straw, through amber and the various shades of brown to almost black, depending principally on the condition of the oliferous material when the oil is rendered. If 
the fish are fresh, the resulting oil is usually clear, bright, and comparatively odorless and tasteless; and aceording to the extent of the decomposition the oil becomes darker in color until it approaches a very dark brown. However, this is not always the case, for perfectly fresh fish sometimes yield dark oil.

The standard grades recognized for crude oil are $A, B, C$, and D; these terms being synonymous, respectively, with extra light erude, light ceude, brown erude, aud dark brown crude. The bulk of the output is of $\mathrm{A}$ grade, and little $\mathrm{D}$ oil is now prepared except in the Southern factories.

In the process of refining, menhaden oil is first heated and then placed in barrels and chilled in the manner already described for whale oil, either by exposure during cold weather or by refrigeration. This chilling grains the oil, the thick parts collecting together and the limpicl oil forming globules. The grained oil is then placed in bags made of coarse material, and these carefully arranged one above another in a press. On applying compression, the thin oil comes out first and the impurities and stearin are left behind. The oil is then placerl in shallow vats or tanks, exposed to the rays of the sun and protected by a glass covering, where it remains for a day or two. It may also be clarified by treating it with caustic soda and acids, resulting in a short time in a clear, light-straw color.

The pressing of the oil in egnnection with its refinement may be done at a summer temperature, but in that case only a portion of the foots are extracted and the oil has a poor' weather-test. The usual weather pressing during the summer yields 5 per cent of foots, and the oil stands a temperature of about $50^{\circ} \mathrm{F}$. If pressed at a temperature of $32^{\circ}$ to $35^{\circ} \mathrm{F}$, the foots extracted represent about 10 per cent of the original bulk. The foots are used as a substitute for tallow in leathercurrying and also in soap-making, the market price approximating 3 cents per pound.

The products from refining menhaden oil are pressed extra light, pressed light, pressed light brown, pressed dark brown, bleached, extra bleached, oil foots or pressings, bleached oil foots, extra bleached oil foots, and menhaden oil soap. The first four grades of pressed oil are obtained respectively from $A, B, C_{5}$ and $D$ grades of erude oil. A difference of about 1 cent per gallon exists between the prices of each of these consecutive grades of pressed oil. The pressed light is the standard grade, and when that sells at 30 cents per gallon the pressed extra light sells at 31 cents, the pressed light brown at 29 and the pressed dark brown at 28 cents per gallon. On the same basis the bleached sells at 33 cents per gallon, the extra bleached at 35 cents; and the same oils pressed at a low temperature sell for 1 or 2 cents more per gallon. A corresponding price for the unbleached foots is $2 \frac{1}{2}$ cents per pound; bleached foots, $3 \frac{1}{2}$ cents per pound; extra bleached foots, 4 cents, and menhaden-oil soap, 4 cents.

The names "straits oil" and "bank oil" were formerly applied to 
cervain grades of cod oil, but at present these refer, respectively, to $B$ and $C$ grades of pressed menhaden oil, gradual increase in adulteration having resulted in complete change of material.

The principal uses for menhaden oil are currying or filling leather, illumiuating, paint-making, lubricating compounds, tempering, soapmaking, screw-cutting, wire-drawing, and cordage-manufacture, the first three consuming about 80 per cent of the total product. The light and extra light oils are generally employed in illuminating, lubricating, painting, and cordage-manufacture; the light brown for currying, and the lark oil for tempering and screw-cutting.

Large quantities of menhaden oil were formerly used by miners in safety lamps, but leather-currying has been the principal consumer during the last thirty years. Its use in steel works is of comparatively recent origin, and the steel industries now require many thousands of barrels annually.

It was as a substitute for linseed oil in painting that menhaden acquired its first popularity prior to 1865 . The oil as then prepared was of very indifferent quality, the process of manufacture being comparatively erude, and much of the product would not now be considered marketable. ()n account of its being too highly recommended and all grades being sold for the purpose, considerable prejudice was soon created against it as a substitute for linseed oil. But with the improved methods of extraction and refining and with a better understanding of its limitations and technical qualities, these objections have been largely overeome. Its odor makes it undesirable for interior's and restricts its use to outside surfaces. According to MIr. A. II. Gill, its value for drying is somewhat less than that of linseed, but greater than that of poppy-seed, corn, cotton-seed, and sesame oils.

Menhaden stands the weather much better than linseed oil, especially when applied to tin roofs and ironwork. Owing to its glutinous nature, it is harder to apply than linseed oil, and consequently workmen do not always favor its adoption. This use of menhaden oil is now inereasing and a single paint factory in New York City consumes 4,000 or 5,000 barrels annually.

If the oil is cleared from the foots by straining or pressing, cut with sulphurie acid of $45^{\circ}$ strength in proportion of 1 gallon of aeid to 50 gallons of oil, well stirred in and permitted to settle, and then washed down by a spray of cold water played on it, the acid and gluten are precipitated. Thus treated, menhaden makes a good substitute for linseed oil in mixing paints; it may also be used for leather-dressing and, mixed in equal proportions with paraffin and plumbago, makes a desirable lubricator.

The use of menhaden oil for illuminating purposes is confined to miners' lamps, especially in the coal mines of Pennsylvania and West Virginia. For this purpose it is generally combined with mineral or vegetable oils, the mixture giving better satisfaction than the use of menhaden oil alone. It is non-explosive and therefore much safer 
than mineral oil. The luminons effect of refined menharlen oil has been found to be high with a relatively low consumption, as compared with petroleum.

The following treatment of menhaden oil in combination with other substances for painting purposes is recommendet by Andes:

Into a wooden barrel are brought 144 liters of good vinegar, $f$ kilograms of litharge, and of kilograms of zinc sulphate; then the harrel is rolled abont for a long time, and the liquir then poured into 100 liters of fish oil. The mixture is well stirred, and then left at rest for twenty-four hours; when the clear oil is drawn off, seven-eighths of the original quantity is obtained. Fifty-four liters of linseed oil and 9 liters of turpentine are at once added. The liquid is left at rest for several days, and then drawn off. The residue is mixed with an equal volume of milk of lime, and used for painting wood and iron which are exposed to the air.

When whale and cod oils are scarce and high in price menhaden oil is extensively userl as a substitute. Its chief competitors are degras, petroleum compounds, and herring oil made in the United States and in Japan and Europe, the latter competing with it principaly in Europe. For further data in regard to this oil, especially the methods of manufacture, extrnt of production, and so forth, see pages $255-265$.

\section{HERRING OIL.}

The herring, including its related species-the sardine, pilchard, sprat, anchovy, etc.-is probably the most valuable and important product of the world's fisheries, not so much on account of the choice nutritive qualities, perhaps, as because of the enormous quantities obtained. When the product exceeds the demands of the food markets, including those required for salting, cauning, etc., these fish furnish excellent material for oil-production. Their utilization for this purpose is by no means of recent origin, the production of herring oil in the Bohuslan fisheries of Sweden over a century ago ranging between 1,000,000 and 2,000,000 gallons anmually. Nor is it of limited geographical distribution, as the oil is produced to a greater or less extent in nearly every maritime country of Europe, in the British North American provinces, on the norther'n coast of the United States, in Japan, certain parts of the African coast, etc.

Since only the surplus or waste fish are used in oil-making, and as the catch fluctuates greatly, it follows that much variation occurs from year to year in the quantity produced. The figures showing the output in a certain territory are quite unreliable for any year except the one to which they particularly relate. It is therefore difficult to approximate the product of herring oil throughout the world. It seems probable, however, that a reliable estimate would place the average ammual yield at not far from 3,500,000 gallons, of which only a small portion is produced in the United States.

During the fifteen or twenty years preceding 1875 , when fish oils 


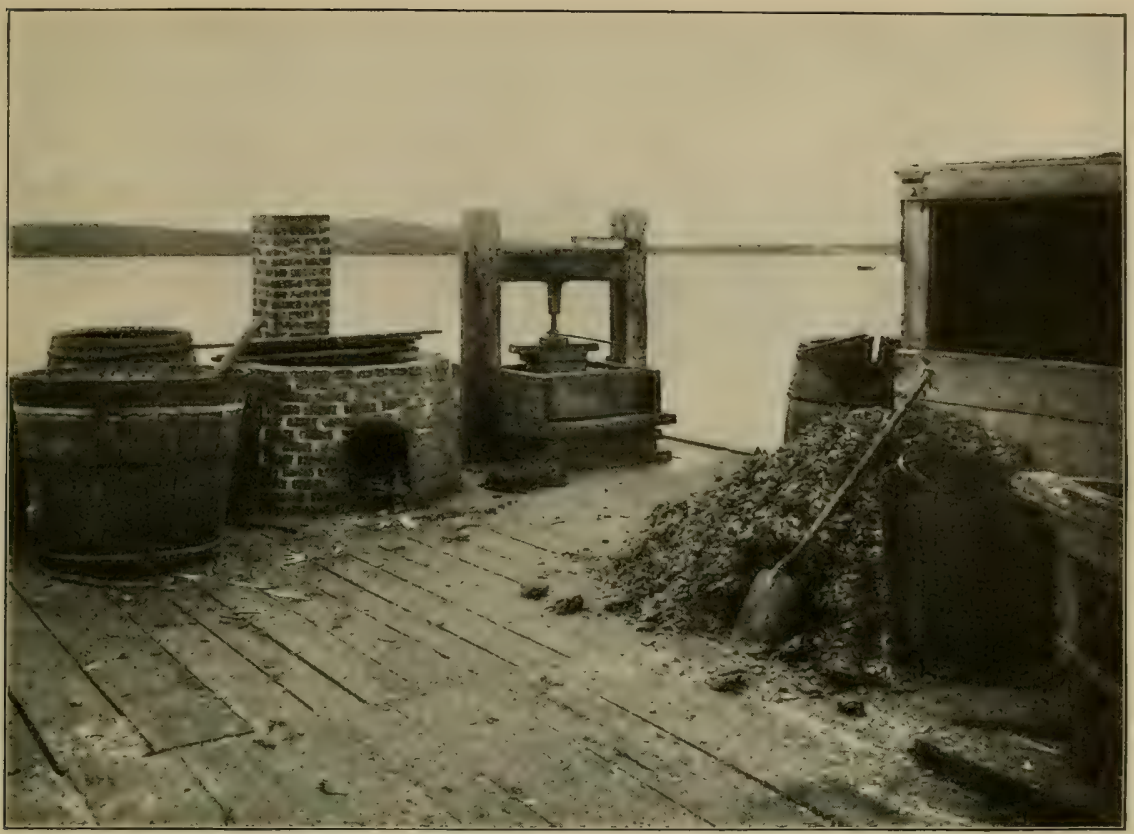

PRIMITIVE FORM OF KETTLE AND PRESS FOR RENDERING OIL FROM HERRING ON THE MAINE COAST.

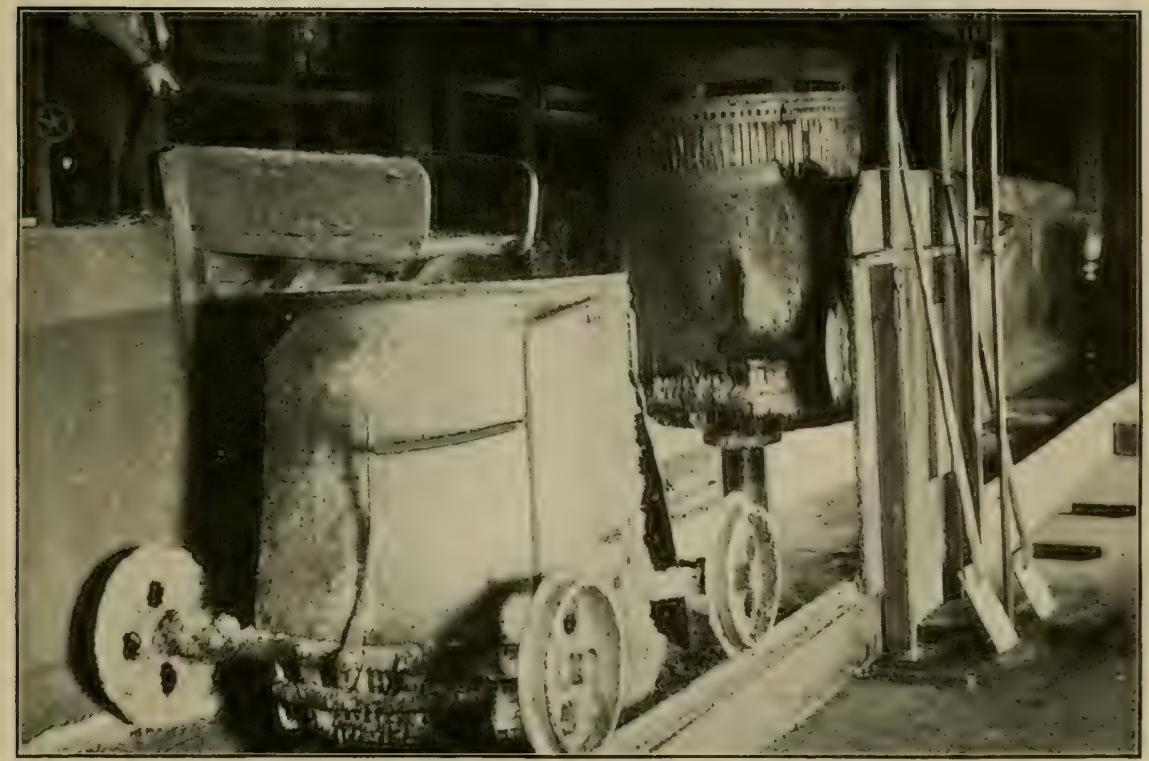

MUDERN TYPE OF HYDRAULIC OIL-PRESS USED IN THE MENHADEN FACTORIES. (SEE P, 262.) 

were worth about double their present values, there were small plants all along the eastern coast of Maine for utilizing the herring in oilmanufacture. The crude material consisted principally of refuse fish taken in connection with the smoked-herring business, especially the small fish which otherwise were valueless. Sometimes the larger herring-over $f$ inches in length-were utilized, but ouly when the comparative prices of oil and smoked fish warranted. This business did not engage the attention of large establishments, but was conducted by many fishermen in a small way, each man working for himself.

As the refuse herring accumulated they were sprinkled with salt, using about 1 bushel to 3 or 4 barrels of fish. After remaining in the salt about 24 hours, they were boiled in open kettles and then subjected to pressure in a screw press with capacity for about $1+1$ barrels. The average yield was about 16 gallons of oil to the ton of fish, but at times the fish were so fat that 20 and even 25 gallons were secured to each tion. The chum or serap was partly dried and then sold as fertilizer at about $\$ 12$ per ton.

The development of the sardine business furnished more profitable use for small herring, and since 1875 the waste from the sardine canneries has provided most of the material for herring-oil production in Maine. This waste consists of the spoiled fish and of the hearls and viscera of fish used in canning, each factory generally using its own refuse. The extent of the business is small. The total output in 1889 amounted to $3 \pm, 316$ gallons of oil, valued at $\$ 8,580$, and 1,941 tons of scrap, worth $\$ 15,528$. Owing to the decreased value of the oil, this business has since fallen off considerably, the output in 1898 amounting to only 12,672 gallons of oil, worth $\$ 2,116$, and 785 tons of scrap, worth $\$ 5,910$.

The method of manufacture is described by Mr. Ansley IIall on page 479 of Report of U. S. Fish Commission for 1896.

Considerable quantities of oil have been prepared from herring on the Pacific coast of the United States. The industry dates from 1867 , but the output was irregular for a number of years. In 1885 the product amounted to upward of 200,000 gallous, much of which is alleged to have been sold as whale oil. In 189:2, according to the Oil, Paint, and Drug Reporter, the output approximated 500,000 gallons, 60 per cent of which was prepared at Killisnoo, Alaska. The yield of oil ranges from 1 to 4 gallons to the barrel of fish. The value on the Pacific coast is about 20 cents per gallon, and the dried scrap sells for about \$25 per ton. This oil is usually quite clear, and the fonts extracted in refining are nearly as white as spermaceti and sell for about 1 cent per pound less than tallow from sheep and oxen, being used largely by soap-makers on the coast.

When herring are taken in the fisheries of Europe in such quantities that they can not be profitably used for food, it is customary to convert them into oil and fertilizer. Herring oil is extensively manufactured in Norway and Sweden, and with the exception of that obtained 
from cod livers, it is now the prineipal fish oil of those countries. The manufacture in Swerlen developed japidly eight or ten years ago, due to the abundance and consequent cheapness of herring. According to Capt. J. W. Collins, the number of factories increased from 3 in 1891 to 22 in 1895 , the output in the season of $1895-96$ amounting to about 500,000 gallons of oil and 16,000 tons of fertilizer. The scarcity and eonsequent high price of herring since 1896 have greatly restricted the output of these factories.

In the preparation of sardines in Europe the heads, viscera, and other waste parts are generally utilized in oil-production. They are cooked and pressed, the oil separated, and the refuse used for fertilizer. This oil is employed in leather-dressing, cordage-manufacture, the preparation of paints for exterior surfaces, and, in some country districts, for illumination. Unfortunately, we have no data bearing on the total extent of the output.

The herring-oil industry in Japan is probably much older than its comnterpart, the menhaden industry in America, but it was in a crude state up to about twenty years ago. The species of fish utilizedknown as "iwashi"-is found in large schools along the Japanese coast, especially on the northern side of the main island, and very large catches are made in the fall and winter, when the fish are fat.

According to a recent report by Consul Van Buren, of Kanawaga, the prineipal fisheries are on the island of Yezo and the peninsula of Ava, near Yokohama. The method of extraction is similar to that employed in the United States. The fish are cooked and pressed and the residuum used for fertilizer. The process of refining is likewise similar to that employed in America, the oil being pressed " in small filtering bags of paper, outside of which are similar- ones of strong cloth. A number of these are placed in a press, which forces out the oil through the pores of this double envelope."

Japanese herring oil contains an unusually large amount of foots, amounting to about 25 per cent, according to some refiners. On account of this, the weather-test of the crude oil is high, from $65^{\circ}$ to $70^{\circ} \mathrm{F}$. Before the introduction of kerosene in Japan, refined herring oil was employed largely for illumination, but that is greatly reduced. It is now used locally in the manufacture of soap, in leather-dressing, in cordage-manufacture, as a body for paints, and for other technical purposes.

Since 1881 large quantities have been exported to Europe, and also at intervals to the United States. At first it found little acceptance on account of its unpleasant odor, due to the crude method of extraction. Another objection was the form of the packages, consisting of second-hand 5-gallon kerosene cans, which proved a nuisance to users of large quantities. The IIamburg market price is about 40 marks per 100 kilograms for the light oil and $37 \frac{1}{2}$ for the brown. The foots, after the process of refining, sell at about 43 marks per 100 kilograms.

It is only when domestic fish-oils are high that Japanese herring oil 
can be profitably imported into this country, and on that account the imports fluctuate largely from year to year. The United States markets will receive it at 3 to 5 cents less per gallon than menhaden oil, but it can not be exported to this country with profit when the menhaden market is less than 26 cents per gallon, since the freights, insurance, import duties, brokerage, etc., would leave very little for the exporter. In 1885 the imports into this country amounted to 101,265 gallons, valued at $\$ 24,832$; in $1886,5,010$ gallons, valued at $\$ 786$; then they were insignificant until 1893, when 191,852 gallons, worth $\$ 30,746$, were receiver. In 1894 the imports were 156,456 gallons, worth $\$ 24,656$. Some very choice specimens of refined oil have been received from Japan for exhibition purposes, thus demonstrating what the factories there are capable of producing, but some of the product sent here for consumption could be improved upon.

\section{OIL FROM WASTE FISH.}

In addition to menhaden and herring, several species of fishes not suitable or available for food are used in oil-production. The use of sea-robil, skates, and bellows-fish taken with menharlen is moted in the account of the menhaden industry. Of these species, the searobin is the most desirable for this purpose, yielding about 8 gallons of oil to the ton of fish. Skates and bellows-fish yield comparatively little oil, amounting sometimes to less than 1 gallon to the ton. This is combined with the menhaden oil, no noteworthy difference being apparent. These fish are purchased by the menhaden factorymen at 50 to 75 cents per thousand, but it would not pay to handle them were it not for the fertilizer into which the solid tissue is converted after the extraction of the oil. The oil of the sun-fish (MLola) is used by some fishermen for the cure of rheumatism.

On the coasts of Alaska and British Columbia, and to a less extent in Washington and Oregon, there is secured a fish elosely allied to the smelt and capelin of the Atlantic coast, which is of considerable value owing to its oil-yielding properties. This is the eulachon or oulahon (Thaleichthys pacificus), called also the "candle-fish," for the reason that the natives use it as a candle in their dwellings, it being capable of ignition and burning with good illuminating qualities. For many years, according to Dr. Tarleton H. Bean, an excellent quality of oil has been made from it by the Indians both for their own use and for trade with the whites. 'The weather-test of this oil is very high, and at ordinary temperature it is opaque and butyraceous; indeed, among the Indians it supplies the place of butter.

According to Dr. A. B. Lyons, of Detroit, eulachon oil contains " about 20 per cent of palmitic and stearic acids, 60 per cent of oleic acid, 13 per cent of an unsaponified substance, which is the most peculiar and interesting thing about it. This substance is of an oily consistency at ordinary temperature in summer, has much lower spe- 
(ifie gravity than oleic acid or any other constituent of ordinary fats (specifice gravity 0.8155 to 0.872 at $53^{\circ} \mathrm{F}$. ), and seems to resemble the unsaponifiable constituent of sperm oil." According to Dr. Schaedler, when eulachon oil is mixed with sulphuric acid ( 1 volume of acid to 5 parts of oil) the temperature of the mixture rises to $121^{\circ} \mathrm{F}$., whereas under similar conditions corl oil rises $10235^{\circ} \mathrm{F}$. This acid does not impart to eulachon oil the beautiful purple color that it does to cod oil, but a deep brown, subsequently inclining to reddish yellow. Under saponification the precipitated fatty acids amount to about 95 per cent of the original bulk of the oil. Efforts have been made to introduce eulachon oil in the markets in competition with cod-liver oil for medicinal uses. It is claimed that it has nourishing and stimulating properties that adapt it to certain cases of malnutrition, and that it is more easy of digestion than cod-liver oil.

Large quantites of lampreys are used for oil-rendering in sonthern Russia. Prior to 1870 the lamprey was not an article of commerce there, except a small quantity used locally as candles in much the same manner as the eulachon on the Alaskau coast. It is now taken in large numbers on the Volga and Kur rivers. A small quantity is pickled for food, but the greater portion of them are used in oil-manufacture. It is reported that between Tsaritsin and Yenotayevsk, on the Volga River, about 50,000,000 lampreys are taken annually, yielding about 100,000 gallons of oil.c When properly prepared this oil is clear and transparent, but it contains a large quantity of glue, and consequently it is quite viscous.

\section{OIL FROM FISH HEADS.}

During the last twenty years the market has received considerable oil made from refuse at the salmon canneries on the Pacific coast. This was first prepared, about 1876 , at a factory abovo Astoria, on the Columbia River. The heads alone were utilized. These were purchased at the canneries at the nominal price of 50 cents to $\$ 1$ per 1,000, that quantity yielding from 30 to 35 gallons of oil." The heads were cooked by steam and the oil expressed from the mass. This product was sold for use on the Pacific coast at prices varying from 22 to 35 cents per gallon aceording to the supply and demand. The output of salmon oil was small until 1895 , when somewhat more than 50,000 gallons was received on the market. In 1899, according to Mr. W. A. Wileox, two small establishments at Astoria for utilizing salmon refuse prepared 19,600 gallons of oil and 140 tons of fertilizer, and one fictory at Anacortes, Wash., producer 22,000 gallons of oil and 350 tons of fertilizer. Only a small portion of this refuse on the coast is used. This oil compares favorably with that from menhaden and, being a waste product, can be prepared at a very low price. The vis-

a The specific gravity at $59^{\circ} \mathrm{F}$, is given by Dr. Schaedler as 0.907 .

b Journ. Soc. Arts, 1884, p. 110\%.

c Fishing and Hunting in Russian Waters, p. 27.

d See Fishery Industries of the United States, Sec. V, vol. I, p. 750. 
cera of salmon yields such a small quantity of oil that usually it is not profitable to attempt its extraction.

In the United States the heads of halibut have been geuerally utilized for oil-manufacture since 1870. They are of no value as food and are discarded in dressing the fish for market. In Gloucester and Boston, the headquarter's of the halibut fishery, they are collected by the oil-manufacturers, cooked, and pressed in the same manner as other waste products. They are placed in large receptacles and treated with steam until the tissues are thoroughly disintegrated, when the oil and water are extracted by subjecting the mass to hydraulic pressure, 1,000 pounds yielding about 20 gallons of oil. The annual product in Boston and Gloucester is about 12,000 gallons, valued at about 30 cents per gallon. When refined by treating with caustic potash, refrigerated, pressed, and sun-bleached, it looks as fine as choice whale oil and is commonly sold as a substitute therefor and at about the same price.

Sword-fish heads are ustially very fat, a single head sometimes yielding one gallon of oil. As a rule, however, 100 heads yield about 65 gallons of oil. It is extracted in precisely the same manmer as in case of halibut-head oil. The quantity prepared is small, probably not exceeding 1,000 gallons annually on the entire New England coast. It is clear and sweet and is probably sold as whale or cord oil.

The heads of other food-fish as a rule contain little oil. Corl and related species, for instance, contain practically none, and in utilizing them for fertilizer in this country, as well as in the British provinces and in Norway, no effort whatever is made to secure oil therefrom.

\section{OIL FROM VISCERA OF FISH.}

The quantity of viscera resulting from dressing food-fish at the markets, canneries, drying establishments, and the like in the United States amounts to upward of 100,000 tons annually. In certain species of fishes this material is very oleiferous, yielding as high as 150 gallons to the ton; but in most species the viscera are so poor in oil as to preclude their use for this purpose, the possible yield in some instances being as low as 4 or 5 gallons to the ton of crude material.

Probably the greatest yield of oil is from the viscera of the blue-fin white-fish and the chub or deep-water herring of Lake Michigan. The quantity ranges from 7 to 16 gallons of oil to the barrel and is much greater in winter than in summer. The average quantity of oil from the waste of lake trout is about 4 gallons to the barrel of 200 pounds. The yield from herring is small, probably not exceeding 1 gallon per barrel. The total quantity of oil contained in the viscera of all foodfish taken in the United States amounts probably to upward of 800,000 gallons. Only a relatively small proportion of this oil is saved.

Very few establishments exist in this country for utilizing the oil contained in the viscera of fish. A majority of these are on the shores

F. C. $1902-16$ 
of the Great Lakes, especially Lake Michigan, owing to the fatness of the waste from chubs (IIoy's white-fish) secured in great quantities in that lake. These establishments aro small, the necessary pots or kettles, boxes, barrels, etc., not exceeding $\$ 300$ in value. The viscera are usually saved by the fishermen in tight barrels furnished by the oil men, who receive this refuse for carting it away; water is added, and the whole mass cooked in large open pots or kettles for a length of time ranging from three to six hours. As the oil aceumulates at the surface it is skimmed off and stored in suitable receptacles, the solid matter being discarded as of no value. When a barrel or two of oil has aceumulated, it is reboiled and coarsely refined.

There are 8 or 10 of these oil-producing plants on the shores of the Great Lakes, and the total output probably does not exceed 20,000 gallons, whereas the total possible is upward of 200,000 gallons. One plant at Sheboygan, Wis, receiving the viscera from a catch of 296,365 pounds of lolue-fin white-fish and chubs and of 110,260 pounds of trout in 189!9, produced 1,180 gallons of oil, which sold for $\$ 301$.

Considerable oil exists in various parts of the body of sturgeon, especially in the viscera and under the dorsal scutes or bosses. In the sturgeon fisheries of Russia it is eustomary to extract this oil and use it not only technically but also for culinary purposes and for food, especially to soften caviar when it is somewhat dry. A few hundred gallons of sturgeon oil are prepared in the United States each year, but no special properties are attributed to it. It sells for about the same price as menhaden oil and is used for similar purposes. As a general rule, owing to its preparation from fresh materials, this oil is clear and bright and of pleasant odor and flavor.

\section{MISCELLANEOUS OILS.}

Alligator oil is much used among tho hunters and swampers of the Gulf States. It is empioyed as a lubricant, an illuminant, for softening leather, and in the treatment of rheumatism, scrofula, ete. Although this oil is rarely met with in commeree, there are probably few professional alligator hunters who do not lay in a supply each season. About fifteen years ago alligator oil was introduced in France for leathercurrying and met with much favor, owing to its imparting greater weight to the leather than whale, seal, or cod oils. It was received from Mexico and Central America and sold in France at about one frane per kilogram, equivalent to about 70 cents per gallon. It is described as of a reddish color, of 0.928 specific gravity, and to consist ehiefly of $6(0)$ per cent of olein, 32 per cent of margarine and stearin, $1 \frac{1}{2}$ per cent of free oleic acid, and 0.02 of iodine. ${ }^{a}$

In many parts of the world oil is extracted from various species of turtle or terrapin and used for medicinal or technical purposes. In the Chesalpake region certain remedial qualities are supposed to exist in the oil of the celebrated diamond-back terrapin. It has been 
recommended especially for rheumatism. But little of this oil finds its way into trade, being for the most part bottled and put away in the family medicine-chest for home use only. The oil from a variety of turtle found in Mauritius and the adjacent islands has had a local reputation for more than two centuries as an excellent remedy in several diseases. On the coast of India turtle oil is prepared for a number of purposes, especially in the composition of a cement or pitch for paying the seams of vessels. It has been highly recommended as a medicinal oil, principally in cases of scrofula and anæmia. It is not often refined, notwithstanding that the percentage of foots is large. When bottled, the solid part is precipitater in an oparue and yellowishwhite mass, leaving the oil transparent and brownish in color. When slightly warmed, as by exposure to the sun's rays, the two parts amalgamate.

Considerable quantities of turtle oil are prepared in the WV est Indies, on the northern coast of South America, on the Seychelles in the Indian Ocean, etc. Not only is the fat of the animal used for this purpose, but likewise the eggrs, of which large numbers are secured on the Amazon and the Orinoco. It is sair that a single turtle may yield is gallons of oil, and that 3,000 eggs are required for an equal quantity. The eggs are crushed, covered with water, and submitted to the heat of the sun, whereupon the oil quickly floats to the surface. According to consular reports, Para receives upward of 50,000 gallons of this oil during some seasons, and a much larger quantity is consumed by the natives inhabiting the shores frequented by the animals.

Turtle oil is used for eulinary purposes, and likewise for illumination, lubrication, and currying.

While the oils of the dugong and of the manatee are comparatively unknown in the United States, they are of considerable local importance in several tropical and semitropical countries, especially in Australia, New Zealand, and Brazil. The oil is obtained from the blubber situated beneath the skin, and each animal yields 5 to 20 gallous. No difference has been pointed out in the characteristics of the oils of these animals; although, obtained in widely separated countries, it is natural that different uses should have developed.

Dugong oil has no prominent odor, is of a pleasant flavor, and when in good condition is almost as limpid as water. It is used in place of butter and sometimes in preference thereto, and as a cooking oil it is sairl to be unrivaled; but it is employed principally as a medieine, its properties resembling those of cod-liver oil, without the unpleasant effects of the latter. It is valued by some medical practitioner's in Australia and New Zealand even more highly than cod-liver oil. Dr. Hobbs, of Queensland, was the first to draw attention to its virtues in Australia, receiving a prize medal at the Sidney Exhibition in 1854. By some persons dugong oil is believed to be efficacious in the treatment of debility, dyspepsia, chronic dysentery, bronehitis, ete. (Oceasionally it may be found in this country put up in bottles with labels 
indicative of an oriental origin, and recommended as a cure for constumption and diserses of the chest and back.

'The oil of the manateo is one of the few blubber oils which does not become rancirl on exposure to the sun, and on the contrary acquires a fine flavor and agreeable odor through such exposure. On the west coast of Africa, in the West Indies, Guiana, and Brazil, it forms an important item of domestic commerce; it is used as a lubricator, as an illuminant, in cooking, and for the table.

Speaking of the American species (MLamatus americumus), Dr. $\mathbf{R}$. Brookes in his " Natural History" states:

The fat which lies between the cuticle and the skin, when exposed to the sun, has a fine smell and taste, and far exceeds the fat of any sea animal. It has this peculiar property, that the heat of the sun will not spoil it, nor make it grow rancid. The taste is like the oil of sweet almonds, and it will serve very well in all cases instead of butter. Any quantity may be taken inwarlly with safety, for it has no other effect than keeping the body open. The fat of the tail is of a harder consistence, and when boiled is more delicate than the other.

The fat obtained from beaver is made into an ointment by the Indians, to which they attribute many curative and medicinal properties, especially its power to prevent frost bites, the anointed parts of the body not being affected even when exposed to the most extreme cold. An old treatise of 1685 , credited to Joanne Mario, attributes marvelous curative properties to beaver oil:

It is efficacious in all maladies which affect the nerves. It is useful in epilepsy, and prevents apoplexy and lethargy; stops spasms and convulsions, and is of great help in giddiness, toothache, asthma, dysentery, and strains.

On the Macquarie Islands, the coast of Patagonia, aud suveral other places in the cold regious of the Southern Hemisphere, large numbers of penguin are caught and used in oil rendering. On Macquarie Island the royal penguin and the king penguin are used, while on the Patagonian coast the jackass penguin is the prineipal species, with smaller numbers of macaronis and red bills. These birds are found on the shores in great number's and are easily killed with clubs. In some localities the breast skin, with the attached blubber, is the only part cooked, the rest being discarded; but usually the entire body is placed in pots and cooked. When thoroughly disintegrated the mass is pressed and the oil thus extracted.

\section{SPERMACETI REFINING AND MANUFACTURE.}

Spermaceti is the solid portion of the crude oil of sperm whales and of cretain other cetaceans. As noted in the chapter on sperm-oil rendering, it occurs in a state of solution in special cavities of the skull and to a much less extent in various parts of the body, especially in the corre of the dorsal hump. The process of its extraction and the separation of the oil therefrom have already been noted in the areount of rendering sperm oil, and it now remains to describe the subsequent treatment of the crude and refined spermaceti. 
After the extraction of the "taut-pressed-oil" the crule spermaceti is heated in vats or tanks, refined, and "whitened" by the introduction of some alkali, as a weak solution of caustic sola or caustic potash, to saponify any adhering oil. Care must be taken during this process that the spermaceti does not saponify, any tendency to do so being overcome by the addition of brine. The refined product is then molded into suitable shapes for marketing. MLst of it is formed into blocks measuring 10 by 12 by 14 inches, and weighing about 62 pounds each. It is also molded into cakes weighing 1 pound, halfpound, quarter-pound, or of any other desired weight.

Spermaceti is white, semitransparent, unctuous or taleose to the touch, of a slight fatty taste and odor. A fracture of a cake reveals broadly foliated, crystallized pieces resembling (quartz. According to Brannt, its specific gravity is 0.943 at $59^{\circ} \mathrm{F}$. It yields nothing to water, and rery little to cold alcohol, but is readily soluble in ether, chloroform, and bisulphide of carbon. It melts at about $125^{\circ} \mathrm{F}$. and congeals immediately below the melting point. Its component parts, according to the same chemist, are carbon, 80.03 per cent; hydrogen, 13.25 per cent, and oxygen, 6.72 per cent.

It is not easy to adulterate spermaceti without detection, since its characteristic properties are readily diminished, the compound being harder, with decreased nacreous luster and smaller foliated, crystals. Tallow is readily detected by the odor given off in melting, and also by the compound making fat stains on paper, which is not the case with pure spermaceti. Stearin renders it harder and smaller foliated, and its presence is readily detected by boiling the sample in a soda solution, effervescence occurring in the adulterated article. If exposed to the air for a long time spermaceti becomes yellowish and somewhat rancid, but when remelted and treated with diluted caustic soda or potash it regains its original condition.

In the early history of the sperm-whale fishery spermaceti was considered of great value for medicinal purposes, and was recommended for many ills of the body, but was employed prineipally for internal applications, especially in eases of inflammation. It was so much in demand before the full development of the fishery as to sell at times for its weight in silver. As it became better known, however, it occupied a minor position in materia medica, chiefly in the preparation of ointments, and its principal use was in candle-making.

The beginning of candle-making in America dated from about 1750. The number of factories increased rapidly, and in 1761 there was a total of eight in New England and one in Philadelphia. In 1772 the first candle factory was established at Nantucket, then the headquarters of the whale fishery, and the number increased until there were 10 in existence on the island in 1792, and an equal number then existed at New Bedford." The business of preparing spermaceti was then separate from the general whale-oil refining industry, the candle- 
makers purehasing the erude head matier only. But gradually the two industres were combined to their mutual alvantage. When the sperm-whale fishery developed 10 its full calpacity, the production of spernaceti was very largo, averaging more than $3,000,000$ pounds ammally from 1835 to 1845 . With the decrease in extent of the fishery, there was a corresponting decrease in the yield of spermaceti, rearching its lowest product in 1890 , when less than 200,000 pounds were prepared.

Spermaceti is among the rery best materials for candle-making, the product being beantifully semitransparent and nacreous, burning with great regularity and with white light of high illuminating power; yet owing to the cheapness of other materials, especially paraffin, only a small pereentage of the candles used at present are made of this material. 'T'o reduce the tendency of spermaceti to erystallize in molding and consequently lower its friability, it is customary to add a little paraffin wax, tallow, stearin, beeswax, or cerasin. The clear natural color of the refined spermaceti is usually preferred in cancles, but sometimes coloring material is introduced, in so small a quantity, however, as not to destroy the transparency of the spermaceti. A yellow tint is imparted by adding gamboge, a red by carmine, and a blue by prussian blue. Owing to the cheapness and excellence of paraffin candles, the consumption of spermaceti in candle-making lias been greatly reducer. The quantity thus used at the present time bears no relation to the extensive use of petroleum wax for that purpose, the consumption of which in Great Britain alone amounts to upward of 50,000 tons annually.

Sperm candles are at present the standard used by the principal gas-examiners for photometric measurements. The rules for the preparation of standard sperm candles for photometric purposes, pullished by the Metropolitan Gas Referees, of London, prescribe that, for the purpose of rendering the spermaceti less brittle, best airbleached beeswax, melting at about $141^{\circ} \mathrm{F}$., shall be used exclusively, and that the proportion of beeswax to spermaceti shall not be less than 3 per cent nor more than $4 \frac{1}{2}$ per cent; the spermaceti itself to be so refined as to have a melting-point lying between $112^{\circ}$ and $115^{\circ} \mathrm{F}$.

The production of spermaceti in 1901 in the United States was about $4(10), 000$ pounds, worth $\$ 100,000$. Of this amount probably 70 per cent was exported to Germany, England, and other foreign countries. Its principal foreign use is in the making of candles, large quantities being made in England aud Germany for ecclesiastical use, especially in sonthern Europe. Minor usos are as an ointment for medicinal purposes, in laundries for produeing a polish on linen, and for self-hubricating cartridges. Of the domestic consumption, probably 5,000 poumcls are used in candle-making and the rest for medicinal and industrial purposes. 


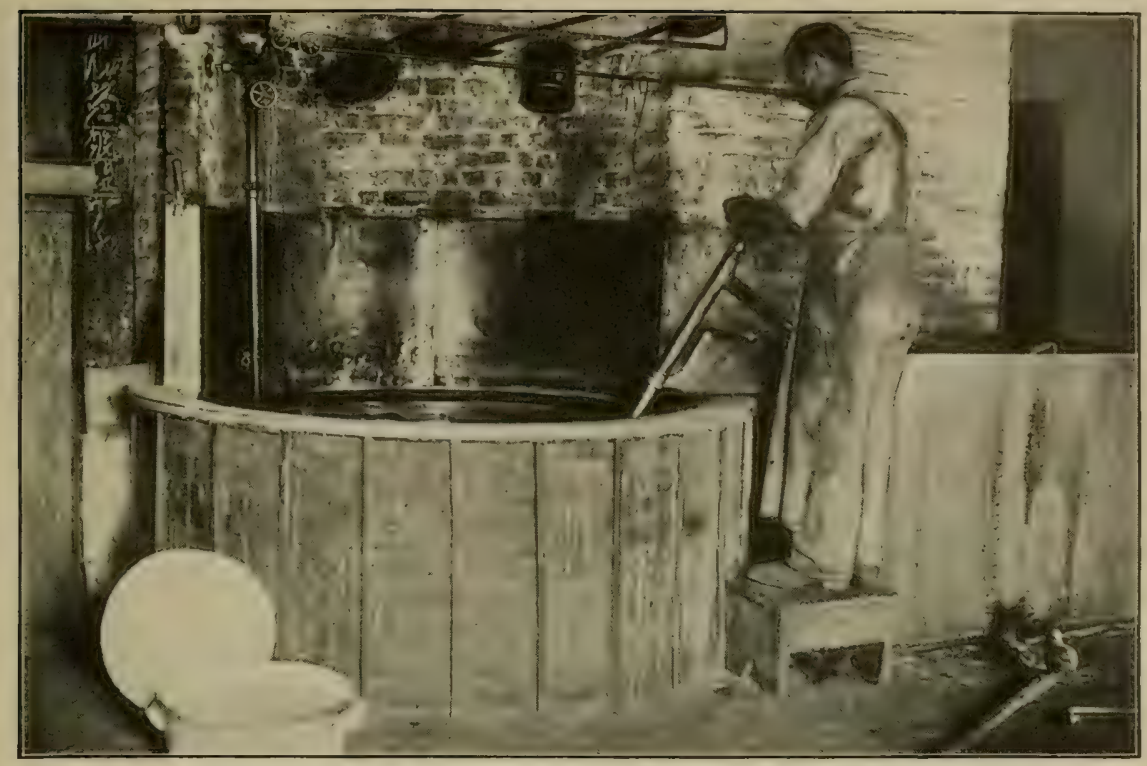

SPERMACETI REFINING. VAT FOR BOILING AND REMOVING SEDIMENT.

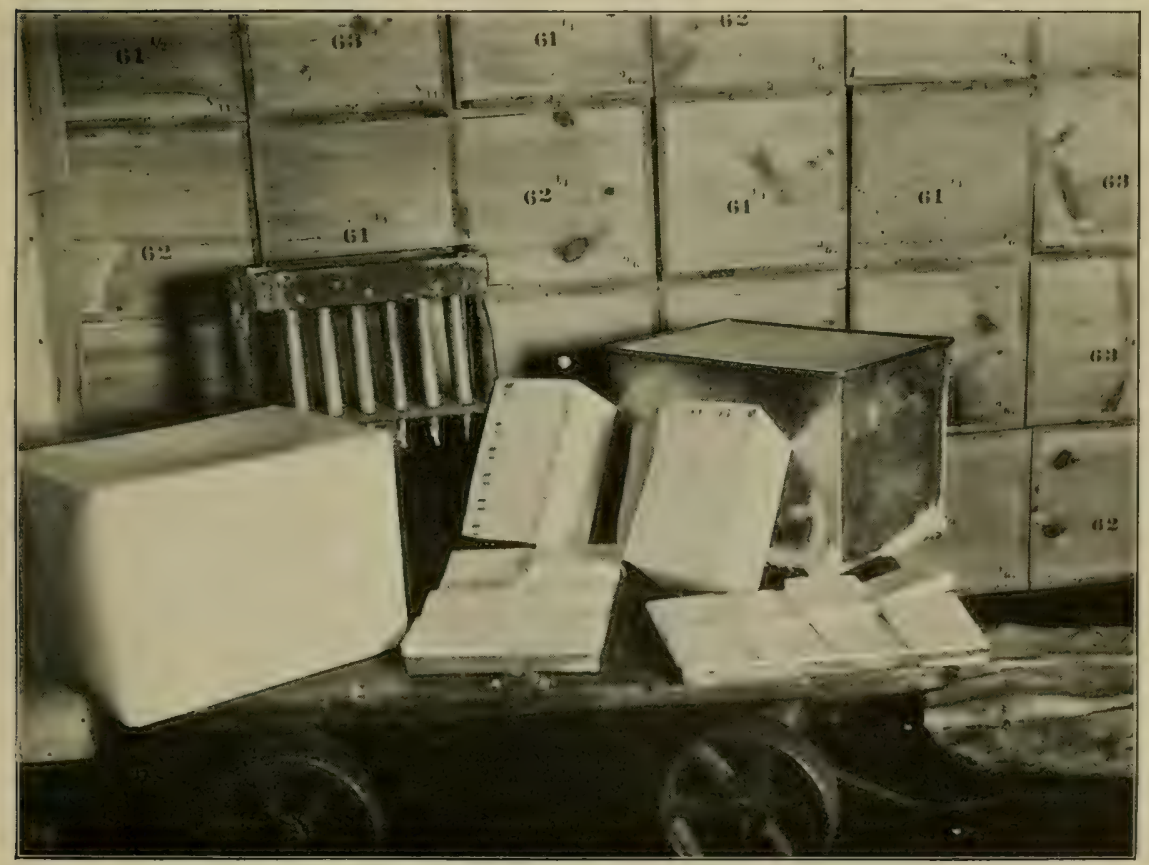

PACKAGES OF BLOCKS, CAKES, AND CANDLES OF SPERMACETI. 

During the year 1901 the value of spermaceti greatly decreased, sales during November being made at 22 cents per pound, the lowest price reached in the last ten years.

No exact figures are available to show the product of spermaceti during a period of years, but the approximate jield may be determined from the figures on page 20t, showing the yield of sperm oil, remembering that about 25 pounds of spermaceti is ohtained from a barrel, or $31 \frac{1}{2}$ gallons, of sperm oil. It should be noterl, however, that considerable crude sperm oil is exported and the spermaceti extracted abroad.

\section{AMBERGRIS.}

Ambergris is a wax-like substance found at rare intervals, but sometimes in relatively large quantities, in the intestines of the sperm whale. With the exception of choice pearls and coral, it is the highest-priceed product of the fisheries, selling at upward of $\$ 40$ per ounce. It has been a valuable object of commerce for hundreds of years. It appears to have heen prized first by the Arabians, by whom it was called amber, and by this name it was first known among the Europeans. The name was later extended to the fossilized gum, the two being distinguished by their respective colors as amber gris and amber jaune.

In the writings of early travelers to the shores of the Indian Ocean and to southern Asia, references to ambergris are by no means infrequent. Before the time of Mareo Polo (125t-1324), Zanzibar was famous for its ambergris. So plentiful was it on the shores of Indian Ocean in the sixteenth and seventeenth centuries that the name was given to various islands, capes, and mountain peaks of that region. It was also found on certain shores of the Pacific, notably the coast of Japan. From their station in Batavia the Dutch traders kopt Europe supplied, and also exported it to Asiatic markets.

Though ambergris was a valuable commercial article, little or nothing was known of its origin before the eighteenth century. Some supposed it to be the "solidified foam of the sea," other's that it exuded from trees and flowed into the sea, or that it was a "fungoidal growth of the ocean analogous to that on trees."

It is now generally conceded that ambergris is generated in cither sex of the sperm whale, but far more frequently in the male, and is the result of a diseased state of the animal, eanserl possibly by a biliary irritation, as the individuals from which it is secured are almost invariably of a sickly appearance and sometimes greatly emaciated. It is not of frequent occurrence, many whalemen with half a century's experience never having seen any. The rictim of the malady may eject the morbific substance, thus furnishing the lumps which have been found on the shores or floating on the seas frequented by sperm whales.

Although ambergris is of such rare occurrence, the sperm-whalers always search for it, especially in cliseased or emaciated whales. It 
is found in all parts of the intestinal canal, but more generally at 2 to i feet from the rent. The instrument used in the search is a common cutting-spade. The presence of the prize is detected by the peculiar foeling or impression on striking it, very much like the eutting of eork or rubber, and also by its sticking or adhering to the spate, or hy its floating ont upon the water when the intestines are opened.

Ambergris occurs in rotugh lumps varying in weight from less than 1 pound to 150 pounds or more. It generally contains fragments of the beak or mandible of squid or cuttle-fish, which constitutes the principal foor of the sperm whale. When first removed from the animal it is comparatively soft and emits a repugnant odor', but upon exposnre to the air it grows harder, lighter in color, and assumes the appearauce it presents when found floating on the ocean. It is light in weight, opaque, wax-like, and inflammable. Its color ranges from black to whitish gray, and is often variegated with light stripes and spots resembling marble somewhat. When dried-the only curing process it undergoes-it yields a subtle odor faintly resembling that of honey. It softens under heat like wax, and in that condition may be easily penetrated by a needle. A proof of its good quality is a polished needle meeting with no obstacle when thrust through it, and if the needle be red hot the substance will exude an oil. It fuses at $140^{\circ}$ to $150^{\circ} \mathrm{F}$., and when heated to $212^{\circ} \mathrm{F}$. it dissolves into a blackish, thick oil, and gradually evaporates, leaving no trace of its presence. When stored for a length of time it becomes covered with dust like chocolate. It contains some moisture that gradually evaporates, reducing its weight, but increasing its intrinsic value.

The amount of ambergris produced annually from all sources varies greatly, scarcely an ounce being obtained in some years, while in others the product may exceed $\$ 50,000$ in value. The small compass within which a very raluable quantity may be stored without attracting attention, and the ease with which it may be brought in where it is deemed advisable to preserve secrecy concerning a find, render it exceedingly difficult to follow closely the imports of the article. IIowever, a brief account is here given of some of the principal masses obtained. In this compilation we are indebted to Mr. Francis H. Sloan and to Messrs. J. and W. R. WVing for information.

Probably the most valuable piece secured previous to the last cen. tury was a 182-ponud lump purchased in 1693 from the King of Tydore by the Dutch East India. Company for the sum of 11,000 thaler's. Its origin is unknown. Probably it was found a float on the sea or drifted ashore. It is stated that the Grand Duke of Tuscany offeren 50,000 erowns for it-with what suceess is unknown.

An Ameriean fisherman is eredited with finding a piece that weighed 130 pounds in a whale secured in 1782 about 150 miles southwest of Windward Islands. This sold for $£ 500$, the low price leading one to fancy that the reported weight is exaggerated. 
Captain Coffin, a British whaling master, stated before a committeo of the House of Commons in 1791 that-

He had lately brought home 362 ounces, troy, of this valualble substance. He had taken this from the anus of a female sperm whale captured off the coast of Guinea, and which he stated was very bony and sickly. At the time he brought this quantity to England the ambergris was selling for 2.s. an ounce, but he stated that he sold his for 19s. 6rl. per ounce to a broker, who exported it to Turkey, Germany, and France, among the natives of which it appear's to have heen long celebrated for its aphrodisiacal properties."

The schooner IT atchman, of Nautucket, is eredited with bringing home from the Bahama Islands, in 1858, the largest mass ever found, weighing nearly 600 pounds. This was on the market for mauy months, as the owners were unwilling to divide it and dealers were ardverse to taking the whole lot, but finally it was sold for $\$ 10,500$.

The bark Sea Fox, of New Bedford, in 1866, secured a :3(1-7)arrel sperm whale off the eastern coast of Arabia. A long-handled cutting spade was thrust into the region of the anus and a piece of ambergris fell out. Some of the men proceeded to eut open the large intestine, which was about 10 feet long and $3 \frac{1}{2}$ inches in diameter, and for the entire length it was literally filled and closely packed with ambergris. They cleand out the stomach and found two large pieces weighing, respectively, 40 and 41 pounds. The ambergris in the large intestine, to all appearance, was originally composed of globular pieces, which, owing to pressure from all sides, were compressed into irregular shapes. The two large pieces found in the stomach were of a different shape from those found in the intestine. They measured abont 36 inches in circumference, were flat on both sides, about 8 inches in thickness, and of a superior quality. The entire mass weighed 150 pounds and was sold to the Arabs of Zanzibar for $\$ 10,000$ in gold.

During the year 1878 the bark Minnesota, in the same locality, found 18 pounds of ambergris in a whale, which was sold in Zanzibar to the agents of the Sultan for $\$ 150$ per pound.

The bark Adeline Gibls in 187s brought in the most valuable lot of ambergris obtained by an American vessel up to that time. It was taken from a 50-barrel bull sperm whale south of St. Ielena, weighed 1323 pounds, and was sold for $\$ 23,2331$. This piece was the only one that a fleet of 12 ressels had taken in 45 years. About the same time the Bartholomew Gosnold secured 125 pounds in the vicinity of New Holland, which sold for about $\$ 20,000$, and the Lettitia brought in 100 pounds, worth $\$ 17,500$.

In 1882 , the bark Falcon, in latitude $16^{\circ} 55^{\prime} \mathrm{S}$. and longitude $11^{\circ} 00^{\prime}$ IV., secured a 28-barrel male sperm whale, which was apparently in healthy condition and without unusual appearance. $\Lambda$ spade was accidently thrust into the abdomen, revealing the presence of ambergris in the viscera. A large piece of an ovate form, weighing about 
(it) poumds, and several smaller pieces, irregularly shaped, were found in the intestinal canal. Some of the ambergris was brownish black on tho outside and some of a grayish yellow cast; the exterior coating was filled with the mandibles of squid. The gross weight was 136 pounds, and it sold for $\$ 14,000$.

Doubtless the most valuable lot over secured was a mass weighing 16:- pounds 11 ounces, obtained in 1891, known as the "Bank" lot, which sold in Iondon for about $£ 10,000$. The following communication from the brokers who effected the sale of this remarkable find furnishes an excellent description of the lump and of the state of the ambergris market:

Abont the end of Angust, 1891, a gentleman called to consult us as to the best means of disposing of some ambergris which had been consigned to his firm. We suggested that if it were brought to us we could examine it and report upon its valine, but when we were informed that the caso which contained it weighed close on 224 pounds and was too large to go inside a cab our first feeling was one of incredulity as to the consigmment being ambergris at all. It was finally decided that the case shonld remain in the strong room of the bank in which it had been deposited for safe custody and that we should go there to inspect it. This we did, and were shown a box measuring about 2 feet $t$ inches in each direction and which we were told had with its contents been insured for $£ 10,000$.

In the presence of the merchant who had consulted us and the bank officials the lid of the case was opened, with the immediate result that everyone beat a hasty retreat from its vicinity, for the horrible smell which issued from the box was overpowering. When the odor had lost somewhat of its intensity, we began to take out the packing and found that the case (which was tin-lined) contained one huge mass of a blackish substance, measuring 6 feet 4 inches in circumference, nearly splerical, and which was undoubtedly ambergris. On being turned out of the case it was found to be saturated with moisture, as were the packings of paper and old grmny which had been put around it to prevent it from chafing to pieces during the royage; and it was the liberation of the gases generated by the salt water and the animal matter which had caused the stench alluded to. By proper treatment this smell was eventually completely got rid of, and the ambergris obtained in marlietable condition. The mass was next weighed and the certificate signed by the interested parties, the exact weight being at that time $2,60.3$ ounces. or 162 pounds 11 ounces. This is probably the largest piece of ambergris which has ever been seen by anyone living, and approaches nearly in weight to the lump of 182 pounds purchased by the Dutch East India Company two hundred years ago.

The next thing to do was to split the lump, so as to see what the interior was like. This was accomplished with the aid of long chisels and crowbars. We then saw that the substance consisted of layers or laminze rolled around a central core, the lamina varying a good deal in texture, color, and flavor. Speaking generally, the onter layers were thin, friable, and shelly; dark, almost black in color. and mixed to a considerable extent with the beaks of the cuttle-fish, on which the whale feeds. As the layers approached the center they were denser, grayer in color, thicker, and of better flavor, until the core itself was reached. This core really consisted of two pieces, one the shape of a rifle bullet, but with a deepish depression like the "kickup" of a wine bottle in the base. It was from 10 to 11 inches high, with a diameter of abont 6 inches at the bottom, tapering upward to abont 2 inches at the top, which was slightly flattened. It was detached from the surrounding layers with the greatest ease, and stood alone, a pure, solid lump of the finest gray ambergris, weighing $\$ 33 \frac{1}{4}$ ounces. Beside this magnificent 
piece was a smaller one, almost spherical in shape and about the size of a very large orange. It was rather darker in color and not of (quite so fine a flavor, but was as easily detached from the surrounding layers as the other. Neither of these pieces contained any of the beaks which were so common in the outer layers, and it is almost needless to say that they realized by far the highest price which was ohtained for any portion of the mass. The layers nearest to the core rere of much finer flavor than the outer and darker. One of them was quite 4 inches in thickness, and the ambergris of which it consisted was of a silvery-gray color, different from the whitish gray of the core, and was of lower specific gravity. The layer outside this again was striated in places with the darker exterior. and the beaks began to show, though not to the same extent as in the black, shelly, exterior layers.

It is a matter of some regret to us that we did not secure a photograph of this extraordinary lump, but the fact weighed heavily upon us that if the real truth about it leaked ont the depression of the market would be so great that we shonld not be able to do justice to our clients, and, consequently, as few people as possible were let into the secret. It is true that reports about it were rife for a month or two, but as nothing anthentic conld be ascertained they gradnally died out, and we have ourselves heen repeatedly assured that the thing was a myth altogether. one gentleman going so far as to tell one of our partners, about three months afterwarls, that he held three-fourths of the total quantity of ambergris in London, not knowing that we were controlling about $1 \frac{1}{2}$ hundredweight.

Probably the finest lot of ambergris received in America was taken in 1894 by the schooner Adelia Chase from a 50-barrel whale near Cape de Verde Islands. It weighed $109 \frac{5}{8}$ pounds and sold for about $\$ 26,000$, the best parts fetching $\$ 350$ per pound. No large finds have been reported since 1894. In 189950 pounds of poor quality was secured by the bark Charles W. BIorgan off the coast of Japan. In 1900 the Morning Star secured 7 pounds, and in 1901 the same ship brought in 20 pounds of medium quality.

Ambergris has been used for centuries in the sacerdotal rites of the church, and, in connection with fragrant gums, it was formerly burnt in the apartments of royalty. It was formerly used in cookery, especially in the East, being added to flavor certain dishes. This custom spread through western Europe to a limited extent. Macaulay refers to rumors in connection with the death of Charles II of England that "something had been put into his broth, something added to his favorite dish of egg and ambergris." The principal use of ambergris, however, was as a medicine and as a perfume, especially in Asia and Africa. Until recently it held a place in pharmacy, being regarded as a cardiac and antispasmodie, somewhat analogous to musk, and was recommended in typhoid fevers and various nervous diseases.

The principal and almost the only use of ambergris at present is in the preparation of fine perfumes, furnishing an important ingredient in the production of choice bouquet of "extracts." It also acts as a "fixer" and serves to impart homogeneity and permanency to the different ingredients employed. For perfumers' use it is generally made into an essence or tincture by dissolving 4 ounces in a gallon of alcohol. This is facilitated by first crushing and mixing it with sand. 
Perfumers axereise much care in the selection of the ambergris which they use. The wholesal dealer grades his stock of the material according to its odor, appearance, cte. But this is ly no means sufficient for the trained olfactory sense of the perfume-manufacturer. Before determining the use of a special lot he tests it by his own standards, and these tests may extend over a month, especially for durability of perfume. Some manufacturers prize most highly those lots and grades which another manufacturer would not accept. The selection of just the proper quality to produce the desired bouquet forms one of the niceties of the perfumer's art.

The value of ambergris depends largely on its scarcity at the time and its frectom from impurities. During the last thirty years it has varied in price from $\$ 5$ to $\$ 40$ per ounce. At the present time it is quoted at ss to $\$ 30$ per ounce. In 1880 crude ambergris lorought home by the whalers was sold at $\$ 10$ an ounce and the fried article at $\$ 20$ an ounce. In 1876 the value, llied, was $\$ 25$ au ounce. In the London Price Current of Colonial Produce in 1807 ambergris is quoted at $40 \mathrm{~s}$. to 45s. per ounce for "gray, fine." Considering the respectire purchasing powers of money two centuries ago and at the present time, that price is quite equal to the average value in recent years. 



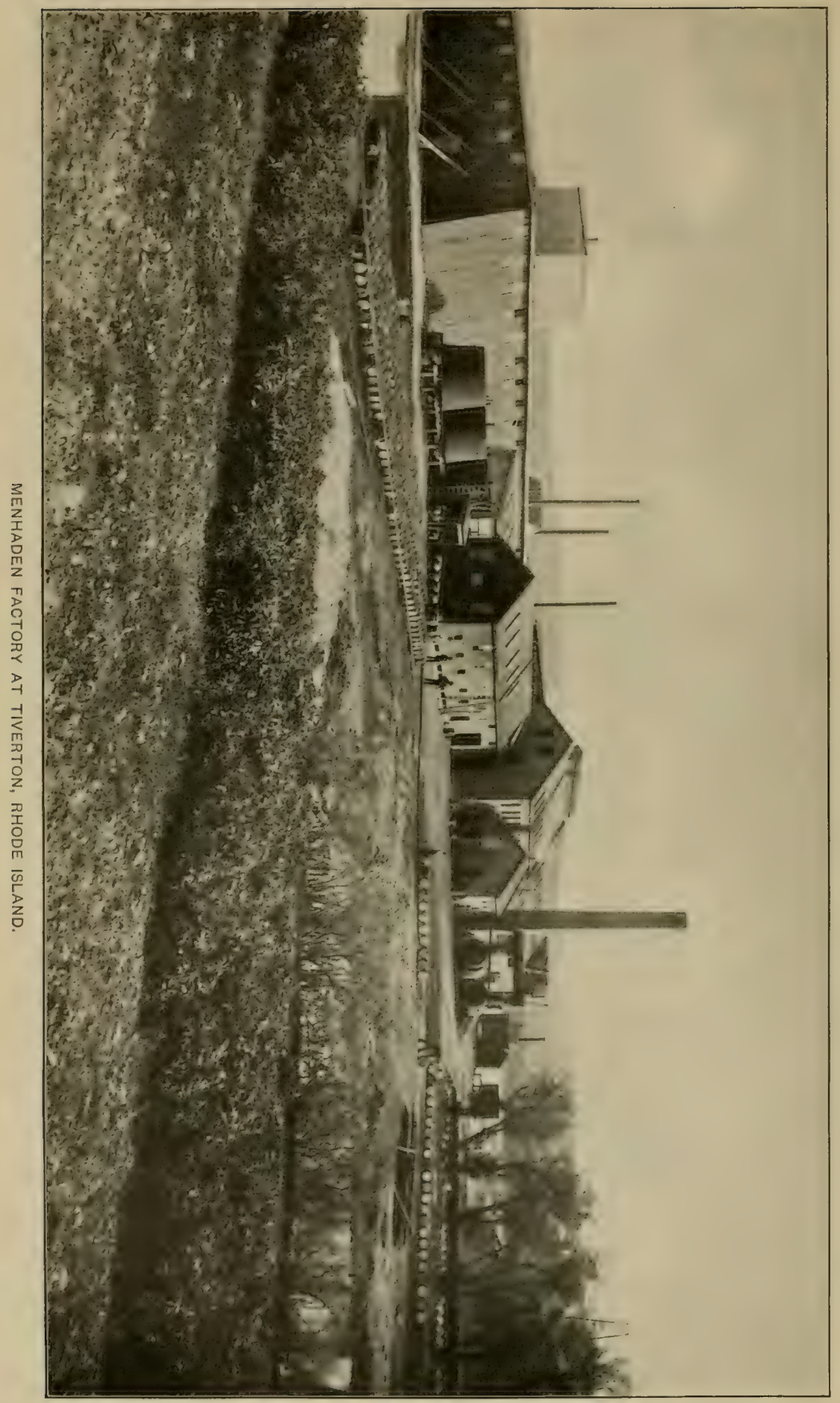




\section{AQUATIC PRODUCTS AS FERTILIZERS.}

\section{GENERAL REVIEW.}

A fertilizer is any substance added to the soil for the purpose of producing a better growth of crops. The food required by plants is supplied in part from the atmosphere, but principally from the soil. If the supply of any one of the necessary ingredients be deficient, a small crop is the result; and tho purpose of fertilizers is to supply the plant-foods lacking in the soil.

The general use of fertilizers is of comparatively recent origin, yet the preparation of these substances supports an extensive industry, employing a large amount of capital and many thousands of men. Compared with the immense quantities of barnyard materials, phosphate rocks, etc., the use of aquatic products for fertilizer is relatively small, yet it is by no means unimportant in the fishery inclustries.

Fish, seaweeds, shells of mollusks and crustaceans, and various other aquatic products have long been known to possess rich fertilizing properties. All kinds of fish can be used for this purpose; but, owing to the greater value of choice species as food, only the nonedible ones and the waste parts are utilizer. The menhaden is the only fish taken in great quantities in this country especially for conversion into fertilizer. The output of this species is very large, amounting to 30 per cent of the total eateh of tish in the United States, and its capture maintains one of the most extensive and vigorously prosecuted of the American fisheries. Compared with that from menhaden, the quantity of fertilizer made from other fish is small, and only such are used for this purpose as can not be profitably employed in any other way.

The original use of fish for fertilizing purposes was in a fresh or green state, and they were added to the soil directly after their cap)ture, although, of course, no special effort was made to preserve their freshness. Before the adrent of the colonists in America, the Indians were accustomed to manure their small crops of com by placing one or more fish in each hill or by spreading then broadcast over the field, and this practice was followed by the early settlers. Owing to the original richuess of the soil and the limited agrieultural operations, the use of fertilizers was of comparatively small extent until 
the latier part of the eighteenth century. It appears that fish were them employed for this purpose all along the Atlantic seaboard from Maine to North Carolima wherever they were obtainable in sufficient quantities.

Fresh fish contain usually from 65 to 80 per cent of water and from 1 to 16 per cent of oil. Neither of these has any value as a fertilizer. On the contrary they decrease the portability and storage qualities of the constituents, and the presence of the oil is prejuclicial to the deconposition of the fertilizer when applied to the soil.

Early in the nineteenth century the fiannmen occasionally extracted the oil from the fish when the avover were unusually fat, thus remoring an injurious ingredient, for which valuable uses were found. This resulted gradually in the establishment of factories for removing the oil, and likewise most of the water, so that the fertilizing substance might be in better condition for transportation. At present most of the fish used for fertilizer are treated in this mamner, even the farmer-fishermen finding it more profitable to sell their catch at the factories and purchase the scrap; but large quantities of fish in a fresh state are yet used precisely as was the custom three hundred years ago.

Owing to its great abundance, combined with its nonerlible qualities, the menhaden is the principal fish used for fertilizer in this country, and the quantity used annually is about $800,000,000$ in number, or $2 \pm 0,000$ tons round or live weight. Of these fully 99 per cent are handled at the factories, and the remainder are used in a fresh or green state. With the menhaden are taken some skates, sea-robius, bellows-fish, and other waste fish. Aside from a few that may be taken with the menhaden, and occasionally some river herring or alewives, no other fish are captured in the United States especially for fertilizer to any great extent.

Formerly nearly all the waste produced in dressing tish for market was thrown away as useless; but in recent years, in the fisheries as in other industries, the utilization of waste material has been made a subject of careful investigation, and many substances formerly considered refuse àre now found to contain elements of commercial value. The dressings at the fish markets and at the fishing centers, the refuse of camneries and boneless-fish factories, and even the carcasses of whales are turned to account in the production of fertilizer. In arliition to these materials, the farmers use large quantities of seawecds, horseshoe crabs, oyster shells, clam shells, etc.

The total annual product of menhaden fertilizer in the United States according to the latest returns amour ved to 85, 830 tons, for which the prorlucers received $\$ 1,539,810$. It is difficult to approximate the quantity of other fishery products used for fertilizer, but it is estimated that the waste fish of all kinds amount to about 20,000 tons, worth \$200,000; horseshoe erabs, shells of shrimp, etc., 800 tons, worth 
$\$ 16,000$; shells and agricultural lime, 60,000 tons, worth $\$ 150,000$, and seaweeds, 250,000 tons, worth $\$ 312,500$, making a total estimated output for this country per year of 416,630 tons, worth $\$ 2,118,310$.

\section{THE MENHADEN INDUSTRY.}

The menhaden belongs to the Chupeider or herring family, and is about the size of the common herring of the New England coast, hut somewhat deeper and more robust. It is not considered a food-fish and is rarely eaten, owing to the abundance of bones, although the flavor is not unpleasant. However, it is one of the most important of all of the species on the coast, being the principal source of bait during the summer, in addition to its use in the manufacture of oil and fertilizer.

The menhaten occurs all along the Atlantic coast of the United States from Maine to Texas, and most abundantly between Cape Cod and Cape Henry, except that during certain years it seeks the coast of Maine in enormous quantities. It appears on the approach of warm weather, ranging from March and April in Chesapeake Bay to May and June on the Maine coast, and remains until late in autumn. Its bathymetrical range exteuds from the inland limits of salt water to the Gulf Stream, but probably 95 per cent of the catch is made within 2 miles of the coastal line. It is captured principally by means of purse seines, operated from steam vessels with carrying capacity for several hundred thousand fish.

About a quarter of a century ago several important reports relative to the menhaden were issued. The first was that of Messrs. Boardman and Atkins, made to the Maine board of agriculture in $1875 .^{\circ}$ Three years later was issued the report of Mr. Luther Maddox. ${ }^{b}$ Each of these related especially to conditions existing in the State of Maine.

In 1879 the United States Fish Commission published the important report of Dr. G. Brown Goode, containing voluminous notes on the natural and economic history of the menhaden, with many extracts from previous reports on the subject. ${ }^{c}$

Many changes have been made in the methods of utilizing the menhaden since those papers were written, but they are yet the principal authorities in regard to the natural history of the subject, and the present writer is prepared to add little. Indeed, such alditional matter would scarcely be in place in this paper, which is restricted to the economic use of menhaden in the preparation of oil and fertilizer.

\footnotetext{
$a$ The Menhaden and Herring Fisheries of Maine as Sources of Fertilization, hy Samuel L. Boardman and Charles G. Atkins, 1875 , pp. 67 .

$b$ The Menhaden Fishery of Maine. Portland, 1878, pp. 46 .

$c$ The Natural and Economic History of the American Menhaden, hy G. Brown Goode. Report U. S. Fish Commission, 187\%, pp. 1-5\%9.
} 


\section{HISTORY AND EXTENT OF THE INDUSTRY.}

$A$ century and more ago, when a much larger number of the home refuisites were prepared by consumers than is the case at the present time, it was a part of the duties of many farmers along the Middle Atlantic coast to derote a few weeks each spring to taking menhaden for the purpose of fertilizing the eultivated land. Large shore seines made of cotton twine were employed, and in some localities these were owned jointly hy several farmers of the vicinity. The length of some of these seines was 3,000 feet or more, and frequently the eatch at a single haul numbered several hundred thousand fish, although the average quantity was nearer 10,000 or 12,000 . This farmer-fishery has continued up to the present time, but its extent is now very much reduced, owing to the ease with which prepared fertilizers may be purchased.

Following upon the development of this use of fresh or green menhaden came the discovery that the oil was valuable for painting, leather-dressing, ete. Some of the farmers would provide a few casks or hogsheads which they partly filled with fish, adding water to cover them, and with weighted boards placed on top to keep the mass down. On the disintegration of the fish through putrefaction they were oceasionally stirred with a long pole to break up the mass and liberate the oil, which floated to the surface of the water and was skimmed off from time to time. After several weeks the oil ceased to flow, and the residuary mass was used as fertilizer. For many years the extent of this business was very small and the product was entirely for home use.

The first improvement in the above process consisted in boiling the fish in kettles to facilitate the extraction of the oil, the boiled fish being then placed in casks, as above noted, resulting in a much larger product. I3y 1830 the cooking of the fish was quite general amoug the few persons engaged in extracting oil from menhaden. The oil was dark and crude, and used only for rough painting and leatherdressing, the marlict being restricterl to the neighbor's of the manufacturers. The use of kettles, however, involved a great waste of heat, and the business was of very little consequence until the introduction of steam in cooking the fish. The first steam factory, aceording to the late (apt. E. T. Deblois, was a small one built in 1841 near Portsmouth, R. I.

In 1850 Daniel Wells built a factory on Shelter Island, New York. 'That was the first factory of considerable size on the coast, and the "quantity of fish handled amounted to $2,000,000$ or $3,000,000$ in number annually; In $1853 \mathrm{Mr}$. WVells built a new factory on Shelter Island, and the old one was removed to Groton, Conn., being the first steam factory in that state. The first factory in Maine was put up in 1863 at South Bristol, and in 1866 eleven factories were built in Maine. In 1869) the factory at South Bristol, M[e., was removed to Fairport, Va., and was the first factory in that State. 
In the meantime the furse-seine had been improved and atopted in the menhaten fishery, permitting the eapture of fish in much larger quantities, and without which the menhaden industry could never have reached its present proportions. The next improvement consisted in pressing the scrapl to extract a greater pereentage of the oil. The first press, operated hy hand power, was built by Charles Tuthill at the Wrells factory, on shelter Island, in 1856. This worked so satisfactorily that soon all the factories were pressing the serap, and in 1858 hychaulic presses were introduced for the purpose. The high price of oil during the sixties, when it reached $\$ 1.40$ per gallon, resulted in much profit in the lunsiness and a large increase in the number of factories, their location extending from Maine to Virginia. Then came the preparation of the scrap in the form of portable fertilizer, the adoption of large cooking-tanks instead of kettles, and the introduction of steam vessels in the fishery.

In 187; floating factories were introduced. These consistert of hoilers, cooking-1anks, mresses, etc., momterl on steamer's, sail ressels, or scows, for convenience in going from place to place to follow the movements of the fish. Probably half a dozen of these were in use in 1880; but owing to the lack of convenience for crying and handling the scrap, this form of factory was soon ahandoned. Another disadvantage of a floating factory is that the constant movement of the ressel prevents the oil from settling, and it remains cloudy and fails to feteh the best market price.

The husine'ss continned to (xpand until it reached high-water mark in 185t, when 458,592, , (591 lish were eaught, yielding 3,722, 927 gallons of oil and $68,86: 3$ tons of seralp, vilued at $\$ 2,800,000$. Since that time great improvements have lreen made in the methods of the industry, but owing to the low price of oil and s(crap), resulting from competition with other productis, the profits hare not been so great, and many factories have been dismantled. The largest catch of tish in any one year, aceording to figures of the U. S. Menhaden Oil and Guano Association, was $858,5 ! 9$, , 691, taken in 1884; the smallest was $229,623,750$, secured in 1892 , ant the average catch during the last thirty yeats approximates 501,0n(1,000 annualy. The incomplete returns for 1!10? indicate that the catch exceeded $900,000,000$, a greater quantity tham for any previous year.

There are two separate and distinct sets of figures showing the extent of the menhalen industry during recent years. The first comimises the returns made by the U. S. MEmhaden ()il and (trano Association, organized in 1873, and covers the operations of the factories in the L'nited States during each year from 187:) to 1898 , inclusive. The second series represents the returns marde by the agents of the United States Fish commission for certain years from 1880 to 1902. Slight differences exist in these fignres, but in the main they agree closely. 
The following summaty shows the returus made by the Tnited States Menhaden Oil and Guamo Association:

Statement of the arfent of the menharlen industing of the Thited states in erach

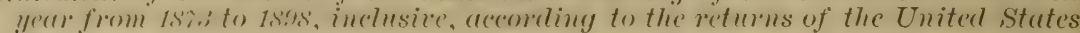
Mentuaden Oil and Guano Association.

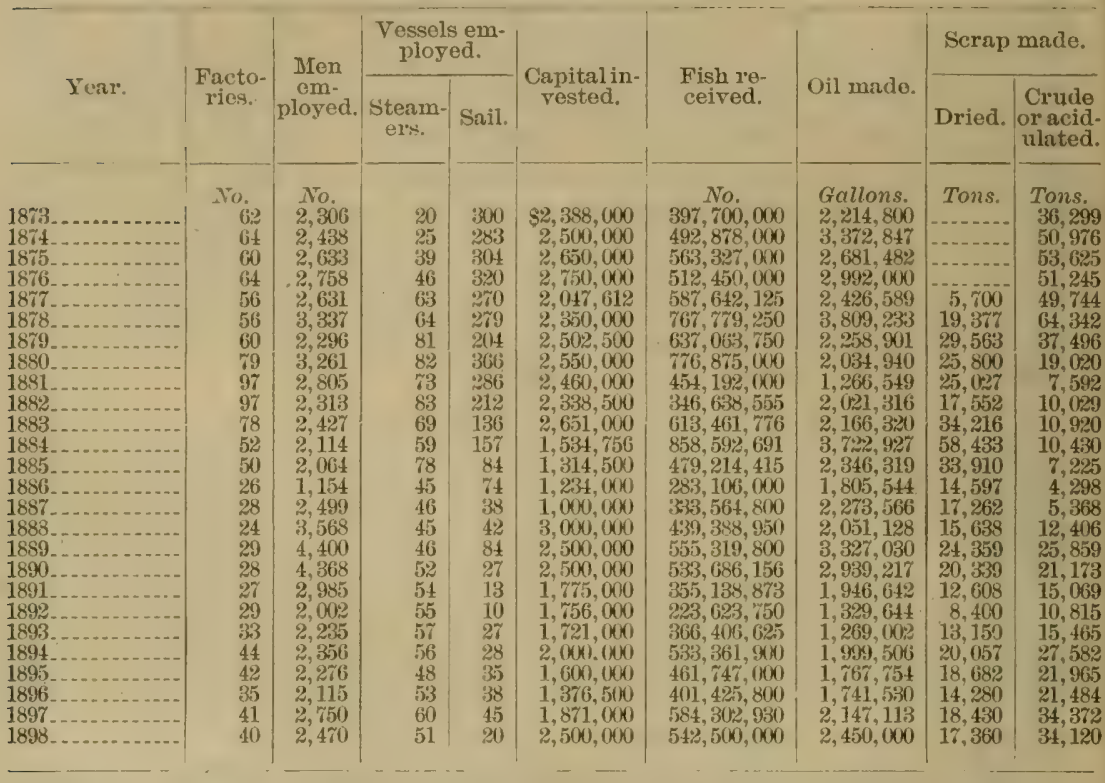

The following summary shows the extent of the menhaden industry according to the latest returns of the United States Fish Commission. The figures for Connecticut, New Jersey, and Virginia for 1902 are not yet available, and there have been no operations in Texas since 1901:

\begin{tabular}{|c|c|c|c|c|c|c|c|c|c|c|}
\hline States. & Year. & $\begin{array}{c}\text { Facto- } \\
\text { ries. }\end{array}$ & $\begin{array}{l}\text { Fish } \\
\text { received, }\end{array}$ & Oil ma & ade. & Dried & serap. & $\underset{\text { Scr }}{\text { Acidl }}$ & $\begin{array}{l}\text { ulated } \\
\text { rap. }\end{array}$ & $\begin{array}{c}\text { Total } \\
\text { value of }\end{array}$ \\
\hline $\begin{array}{l}\text { Rhode Island } \\
\text { Connecticut } \\
\text { New York... } \\
\text { New Jersey - } \\
\text { Delaware.... } \\
\text { Virginia...... } \\
\text { North Carolina } \\
\text { Texas......... }\end{array}$ & $\begin{array}{l}1902 \\
19(k) \\
19 k 1: 2 \\
1901 \\
190 \% \\
1901 \\
1902 \\
1901\end{array}$ & $\begin{array}{r}\text { No. } \\
1 \\
2 \\
3 \\
6 \\
1 \\
15 \\
7 \\
1\end{array}$ & $\begin{array}{r}\text { No. } \\
114,757,900 \\
19,975,700 \\
18 \%, 6 \% 1,700 \\
27,090,000 \\
84,869,100 \\
378,727,331 \\
70,167,800 \\
26,806,500\end{array}$ & $\begin{array}{r}\text { Gallons. } \\
897,188 \\
118,750 \\
1,39 \%, 253 \\
109,789 \\
594,119 \\
723,215 \\
102,052 \\
69,639\end{array}$ & $\begin{array}{r}\text { Value. } \\
\$ 225,912 \\
30,475 \\
35,2,27 \\
25,440 \\
96,724 \\
164,465 \\
22,730 \\
14,654\end{array}$ & $\begin{array}{r}\text { Tons. } \\
450 \\
9,031 \\
1,131 \\
1,642 \\
21,130 \\
1,884 \\
1,710\end{array}$ & $\begin{array}{r}\text { Value. } \\
\$ 12,000 \\
218,217 \\
52,046 \\
39,069 \\
517,872 \\
40,214 \\
30,087\end{array}$ & $\begin{array}{r}\text { Tous. } \\
15,727 \\
1,450 \\
7,410 \\
-8,871 \\
10,591 \\
4,804\end{array}$ & $\begin{array}{r}\text { Talue. } \\
5303,906 \\
-23,450 \\
92,765 \\
110,668 \\
135,388 \\
64,128 \\
\end{array}$ & $\begin{array}{r}\$ 429,818 \\
65,925 \\
664,261 \\
77,486 \\
246,461 \\
817,725 \\
127,072 \\
44,741\end{array}$ \\
\hline Total . & & 36 & 910,065, (ii3) & $3,512,33$, & $933,6 \div 9$ & $36,9 \pi$ & $9(1) 9,5(15)$ & $48.85 \%$ & 630,335 & $2,473,480$ \\
\hline
\end{tabular}

Although very small quantities of other fish are used, mactically the entire catch in the menharlen fishery consists of that species alone. The principal species other than menhaden are sea-robin, skates, and bellows-fish. These are serured mostly in pound nets, especially in those set in Gardiner Bay. They sell for 50 to 80 cents per 1,000, and two or three million are used each year. The sea-robin yields 


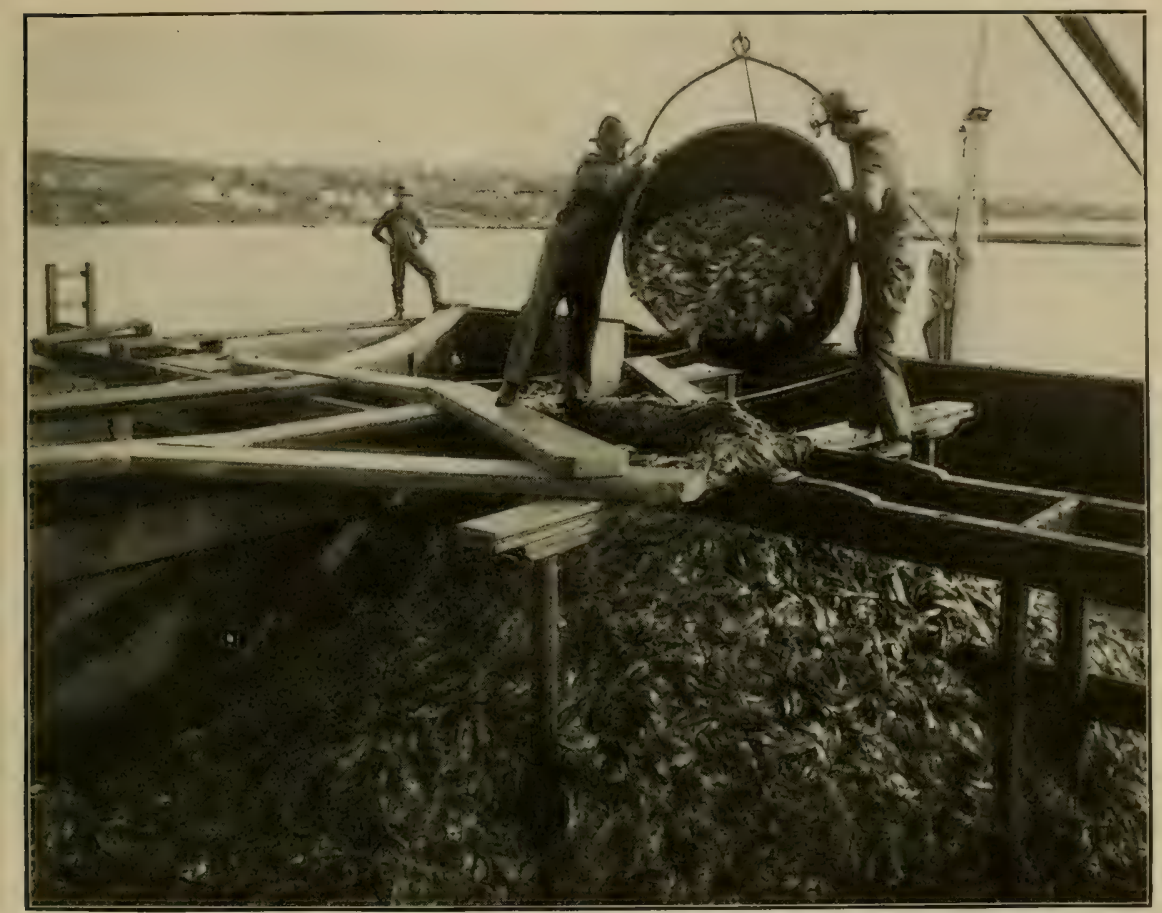

DISCHARGING MENHADEN FROM VESSEL BY MEANS OF TUBS.

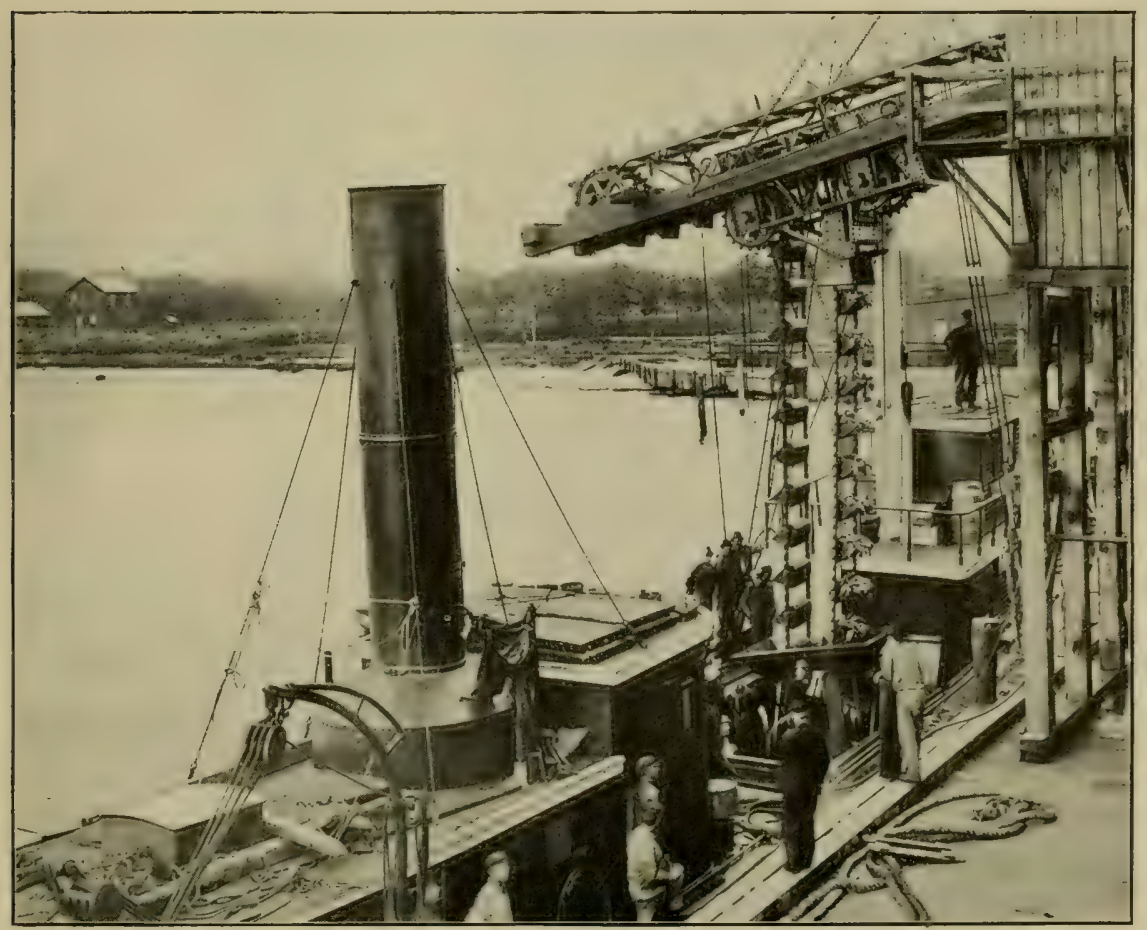

DISCHARGING MENHADEN FROM STEAMER BY MEANS OF BUCKET ELEVATOR, AT PROMISED LAND, NEW YORK. 

3 or + quarts of oil to the barrel. This oil is of good color and is readily sold for menhaden oil, but the scrap is not quite so desirable for fertilizer as that from menhaken. Skates and bellows-fish are comparatively dry, yielding less than one pint of oil to the barrel of fish.

Owing to much contention resulting from the claim that with the menhaden large quantities of choice food-fish are taken and rendered at the factories, the United States Fish Commission, in the season of 1894 , made a thorough inspection of the catches made by two representative steamers of the fleet. This examination showed that in a catch of $27,965,756$ fish only one-third of 1 per cent were food-fish, and only a very small proportion of this percentage was of choice and popular varieties. "As a general thing not enough desirable foodfish are taken by the menhaden steamers to keep the vessels' crews regularly supplied, with fresh fish. As a rule, all the food-fish caught are eaten either by the crews or by the factory hands, but it occasionally happens that schools of blue-fish, butter-fish, shad, river herring, etc., are taken and more fish are thus provided than can be consumed." "

The menhaden factories are distributed along the coast at points convenient to the fishing-grounds. They vary in size and equipment according to the amount of invested capital and the degree of modernness. Some are of primitive type, consisting of two or three large kettles or try-pots and a simple press, the whole, with the accompanying equipment, costing only a few hundred dollars, and are capable of handling only 300,000 or 400,000 fish ammally. From that they increase in size and capacity until the amount of invested capital in a single plant reaches half a million dollars, giving a working capacity of $200,000,000$ fish annually.

\section{COOKING AND PRESSING THE FISH.}

The following account of the methods of the menhaden industry represents observations and inquiries made by the writer luring the last four years, and especially in the season 1901. Most of the factories were visited either in 1901 or previously, and all details in the process of manufacture were inspected. The writer wishes to acknowledge in this connection the courtesy of Capt. N. B. Church, general manager of the Fisheries Company; Mr. II. II. Luther, superintendent of the Promiser Iand plant of that company, and of Capt. J. F. Bussels, of the Atlantic Fisheries Company.

There are two principal processes involved in the manufacture of oil and seraly from menhaden, viz, (1) cooking and pressing the fish and ( $(2)$ drying or otherwiso preserving the scrap, the methods varying accorling to the facilities of the plant. The great bulk of the fish are handled at large factories thoroughly equipped with moderu machinery, including bucket elevators, automatic conveyors, continuous steam-cookers, hydraulic presses, artificial driers, etc.

Some of the factories, especially in Virginia, are quite small, with 
primitive methods of work. In one of them a fire is macle muder fom (ast-imon stationaty boiling vats holding about 2 barels of fish each. By means of a trough leading from a pump, water is permitted to rum into the vats. After sufficient cooking, the fish are scooped out with latro dip nets and put on a platform, whence they are pitehed into tub joresses having a lining of coanse canvas. By means of a vertical serew operated hy a horizontal lever, pressure is applied to the mass, and the exuling oil rums through a trough to the oil vals. Another Chesapeake factory has six iron cooking-vats, in which are suspended an equal number of iron latticed baskets containing the fish. After cooking, the baskets are transferred by means of a crane and the fish placed in an hyrlraulic press. This method of cooking was formerly in general use all along the coast frequented by the menhaden.

In the best-equipped factories the fish are removed from the hold of the steamer, where they have been stowed in bulk, hy means of a bucket elevator. This contrivance, so important in the handling of grain and coal, was not introduced in the menhaden business until 1s,00, when a factory at Tiverton, R. I., was equipped with one. $\$ 1$. present, howerer, they are in use in all the principal factories. I3 fore their adoption the fish were shoveled into measuring tuls in the vessel's hold, and these raised and dumped in clevated receiring bins, or into car's holdiug 15 or 20 harrels each and rumning on inclined tramways to the receiving bins, requiring five or six hours to dis charge 1,000 barrels. By using the bucket elevator, with four mento feed it, 1,000 barrels of fish may easily be discharged in an hour. This decrease in length of time required for discharging is frequently a matter of great importance when fish are abundant, as it enables the steamer's to speedily return to the fishing-grounds.

The elevat or dumps the fish into one of a pair of antomatice weighing hoppers, with a dial-scale indicator of 1-ton eapacity. When the reguirerl weight is in the hopper, by means of a lever the incoming fish are directed into the other hopper, and the bottom of the full one is dropled, thus dumping its contents into a eonveyor, which cleposits the fish into a receiving bin with eapacity of 6,000 or 8,000 barrels.

'The weighing of the fish is necessity to secure a record of the (quantity received, furnishing a basis for compensating the catplains of the vessels, and for other purposes. It thus appours that this methor of discharging changes the standand of measurement from bulk to weight. Although it is eustomary to reckon the quantity of menhaten by so many thousand, the fish are not connted. An arbitrary size of ge cubie inches is the standard measurement for each fish, or 20,000 cubic inches to the thousand. Two humbled ponuds represent one barrel, and $3 \frac{1}{3}$ barrels represent 1,000 fish. The size of the fish varies considerably, aud the actual number reguired to make "one thousancl" in measure ranges from 500 to 2,000 in number.

The floor of the large receiving bin slants foward the longitudinal 


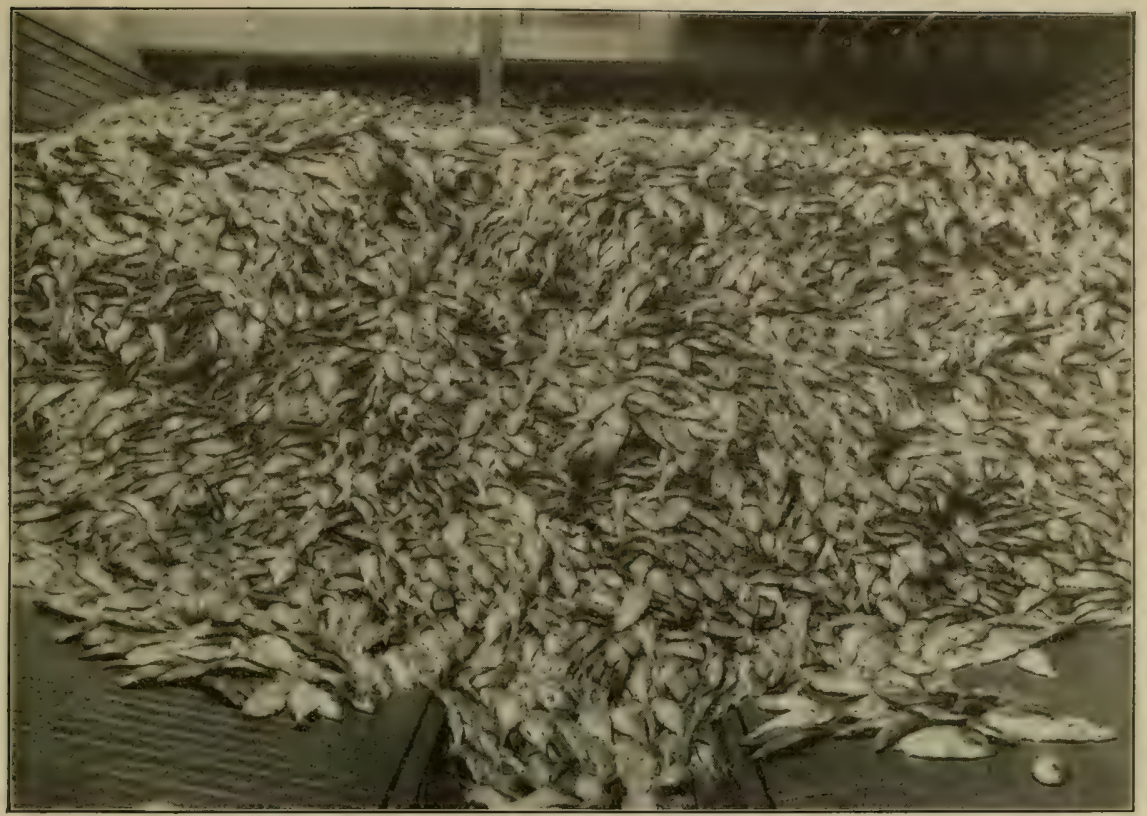

RECEIVING-BIN FOR FISH AT MENHADEN FACTORY.

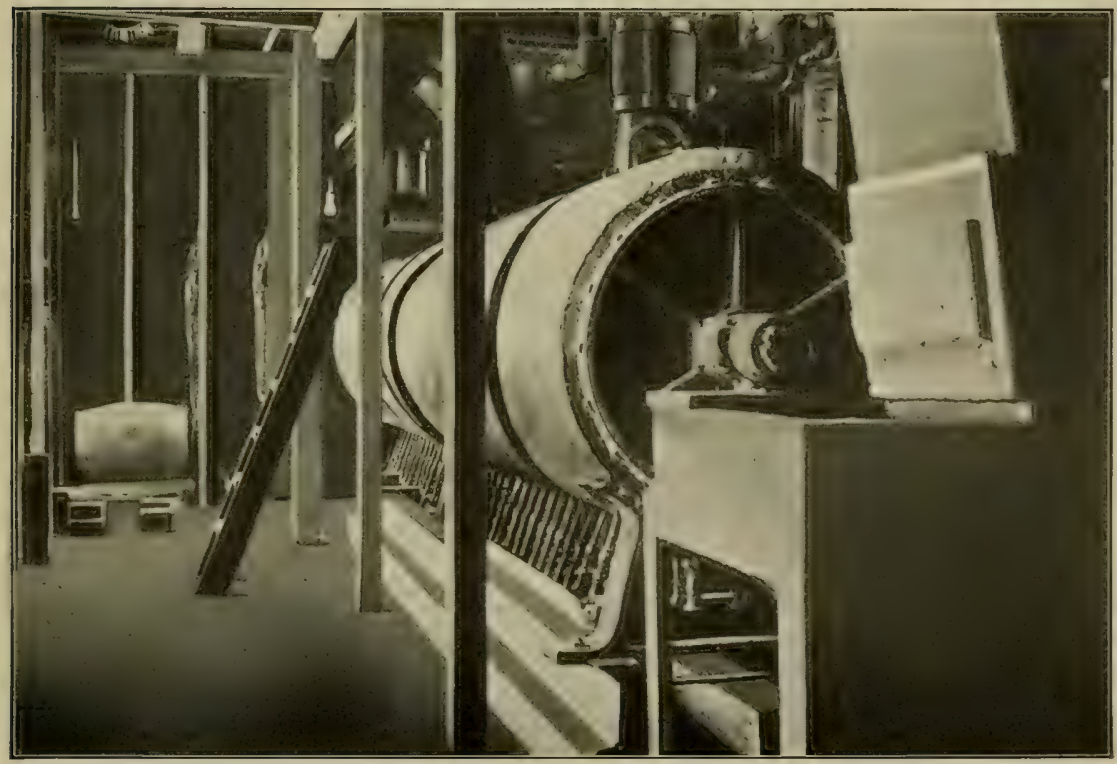

CONTINUOUS STEAM-COOKER, USED BY FISHERIES COMPANY AT PROMISED LAND, NEW YORK. 

middle, where is stationed a trough or chute with a covering movable in sections of short length. In this trough runs a conveyor, ansisting of two parallel endless chains, between which, at intervals of 2 or 3 feet, are attached pieces of board which act as buckets to push the fish along through the trough when a section of the covering is removert. This trongh with endless carrier is in use in practically all the latrese factories, irrespective of the method of eooking. It carries the lish to the rooking bins, or to the stean cooker in case the latter is employed, traps or slides in the bottom of the trough permitting the distribution of the fish into any of the tanks desired.

The cooking bins or tanks are large rectangular wooden hoxes having capacity of from 5() to 100 barrels each and arranged with a lattice platform, about $t$ inches above the bottom, on which the fish rest. Between the lattice platform and the bottom there is a nest of steam piping comnected with a pipe leading from steam boiler's. A water pipe also leats into the bin, through which salt water for cooking the fish is pumped into the tanks to a depth of about 1 foot or more. For convenience in handling the materials, the bins are eommonly arranged in two adjacent rows, and ahove them runs the endless carrier conveying the fish from the receiving bin. On the outer side of each of the two rows of tanks runs a track leading to the presses, to he deseribed later. When the bins are filled with fish, steam is turned into the piping in the bottom and heats the water, thus cooking the fish, rexdueing them to pulp, and breaking the oil cells. The amount of the cooking determines the extent to which the oil is removert. If carried to an extreme point, nearly all the oil can be pressed out. But severe cooking results in greatly damaging the cuality of the oil and in loss of a certain amount of the nitrogenous compounds so important in determining the commercial value of the scrip. It is, therefore, important that the heat be so regulated as to extract as much oil as practicable without injuring the quality and with a minimum loss of nitrogen. The requisite degree of cooking is reacher when the fish crumble to pieces easily. A high degree of temperature is maintained for about fifty minutes, when the mass of fish is broken up and then permitted to simmer for four or five hours. The fres oil and water are then drawn off and the fish permitter to drain for several hours.

During the last two or three years the largest factories on the coast have been using continuous stean cookers. The most popular form is constructed so that a conveyor transmits the fish into a steam-1ight receptacle, into which a large number of jets of steam are introduced, which thoroughly cooks the mass. The process is continuous, requiring about fifteen minutes for the fish to pass through, and the capacity of each cooker is about 600 barrels per hour. From the cooker the mass of fish is carried loy means of a screw conveyor into an upright elevator casing, whence a bucket elevator carries it to receiving tanks, where it drains overuight. These tanks are usually about 10 feet scuare 
and if feet deep. Most factories use for this purpose the bins used in cooking before the adoption of the steam cooker. One factory has a total of 52 tanks for draining the fish.

The oil and water draining from the cooked fish is pumper or led off through pipes or troughs into the oil room, where it is received into large vats. After draining for ten or twelve hours, the mass of cooked fish is forked out of the tanks and thrown into (arlis for pressing.

The curbs are of various designs. The most eommon form is a cylindrieal tul with a hinged bottom firmly attached to axles, which are provided with wheels so as to run on a tramway. The staves are male of metal slats and are held together by stout bands. They are set at a convenient distance apart to allow the oil and water to pass through, and increase in width from the center to the bottom enough to overeome the enlargement of the opening between the slats consequent upon their outward slant. This outward slant commences at about the middle of the eurb and extends to the lower end, and its effect is to give the eurb an increasing diameter as the bottom is approached, so that the hard cake remaining after pressure is relaxed can be readily forced out at the bottom. Through the center of the curb runs a hollow core, stoutly constructed of metal slats. The bottom is attached by means of hinges to the lower end of braces, which are firmly fastened to the lower band of the curb, the axle, and the middle band. The opposite side of the bottom is suspended by means of latches which are eaught and held by a bolt sliding freely within the braces and actuated by a lever pivoted upon the axles. The axles are also braced by stays on either side of the tub, which pass from one axle to the other, and, being curved to fit closely to a section of a band, are firmly attached thereto. The eapacity of each curb is about 7 barrels. A metal shield surrounds it to protect the workmen from the spattering oil and water when pressure is applied.

The curb, having been filled with cooked fish, is run along the rail and placed under a solid stationary head made to fit closely inside the eurb and against which the fish are pressed as the curb is slowly laised by a powerful hydraulie press. This forces out most of the remaining oil and water, which exudes from between the slats, and by means of troughs and pipes is conveyed to the oil room. On relaxing the pressure the curb resumes its position on the railway and is moved from the press stand and the core removed; the bottom is swung out of the way, and the hard cake remaining in the tub is foreed through the bottom, falling into receptacles underneath.

Under ordinary conditions from 5 to 7 per cent of the oil is left in the pressed fish, it being difficult to remove all the oil and water, owing to the gelatinous or gluey state of the fish as a result of the cooking. In some factories the chum or pressed fish is washed with hot water and then repressed, but this is searcely profitable if the first 
pressing is properly performed. The chum now passes to the scrap) room and its further treatment is describer on pr). $265-2195$.

Alont two-thirds of the total amount of oil obtained runs from the cooked fish while it drains in the vats, the remaining one-third being extracted by the presses. The former is a trifle better than the lat tor', as it is somewhat lighter in color. The two grades are sometimes kept separate, but such is not the general practice.

Among the many methors of extracting the oil which have hern tried but not alopted is the use of fumes of benzine or bisulphirle of carbon. When these are brought in contact with the fish in air-1 ight chambers, they absoxh the oil, the liquid result collecting in tanks at the bottom of the receptacle and the benzine being subsequently expelled by evaporation.

Much attention has been paid to devising a continuous process of cooking and pressing, in which the elements of labor are reduced to a minimum. Wheu the Stanley process was invented, about five years ago, it was thought that the problem was solved and the patent rights were sold for a very large sum of money. In this process the fish are cooked in boiling water in a large, comparatively shallow, semicylindrical tank, the lower portion of which is fitted with a worm conveyor, while near the top is a perforater plate or grating, above which the fish or other solid matter can not pass, but through which the water and oil rise. The material is fed in through a hopper at one end and is discharged at the other end, being carried forward by the worm conveyor, which also reduces the material to a finely divided state, thus enabling the action of the water upon all parts of the material freely to liberate the oil. The oil rises to the surface of the water.in the cooking vessel and escapes through a pipe in the end into a settling tank. From the bottom of this tank whatever water has come over with the oil is pumped back into the cooling vessel, entering at the opposite end from the outlet through which the oil flows and at a point near the surface of the level at which the water in the boiler is constantly kept, thus creating a current which carries the oil constantly forward toward the outlet. The scrul from which the oil has been liberated is carried forward to an outlet in the bottom of the cylinder by the worm conveyor and falls into an upright elevator casiug having elevator buckets ruming upon an endless chain, which carry the material up aud over, dumping it into a receptacle suitable for removing for further treatment. The liquid matter is carried up by the elevator buckets, drains through them, and returns to the liquor in the cooking apparatus. This process, however, has not yet been found sufficiently practical for general adoption.

As long ago as 1858 the Ocean Oil and Guano Company, of Southold, N. Y., used a steam cylinder cooker somewhat similar to the continuous cooker now in use. This is said to have been invented by a Frenchman named De Molon, and is described in a pamphlet issued by the above company in 1860 as follows: The raw fish, in quantities of $1 \frac{2}{3}$ 
tons, are placed in the inner chamber of a rerolving eylinder, with double walls, the space between the inner and the onter walls being filled with steam at about 80 pounds pressure. lidfore ardmitting steam the cylinder is put in motion, so that as it revolves cach fish is constantly ehanging its position. A uniform temperature is maintained by means of ome head of the inner eylinder being perforated to permit the steam generated in the mass to escape through a safoty valve.

In the oil room of the menhaden factories is a sories of reseptacles into which the oil and water are received from the draining tanks and the presses. 'The combined mass of oil and water is first sul,jected to a temperature of $150^{\circ} \mathrm{F}$, which causes them to separate, the oil rising to the surface. It is permitted to overflow to other tanks containing hot water, where it is brought to the boiling-point by means of injected steam. It is important that the oil be separated from the water before the impurities begin to ferment, fermentation causing it to be dark and of lower grade. After settling for a while the oil is withdrawn into another tank and thenee pumped into the storage tanks.

A contrivance for withdrawing the oil from the surface consists of a jointed pipe with open end at top, which in some cases is funnelshaped. This passes up through the bottom of the vat, and the top of the pipe is so arranged that it may he raised or lowered to any desired distance beneath the surface to receive and guide the surface oil into the next vat. Sometimes there is a series of as many as 5 vats, from one to another of which the oil passes, each time becoming purer and purer as it is cooked and drained. The oil is led into the first of the cooking vats through the bottom, the pipe leading nearly to the surface. A second pipe passing through the bottom and terminating with an open top not a great distance above the bottom carries off the water-oil or less pure oil as it settles and conducts it to near the top of the second vat, where the oil and water are furth(r. separated.

At the bottom of each settling tank is deposited a quantity of finelydivided fleshy substance known as "gurry." This is removed from the tanks to the gurry room, where it is treated or sprinkled with sulphuric acid to facilitate the separation of the oil from the flesh fiber. It is then placed in bags, 2 gallons to the bag, and these placed in pairs under a press and subjected to great pressure, resulting in a small quantity of oil. The residum in the bags, consisting of a hard cake, is broken up and either discarded or mixed with the scrap.

When thoroughly separated from the water, the oil is pumped into suitable storage tanks or barreled. 'The refining or bleaching of the oil is rarely done at the factories, but is performed by the oil-refiner's of New Tork, New Bedford, Boston, ete., and the methods and results have already been described on p. 234. 


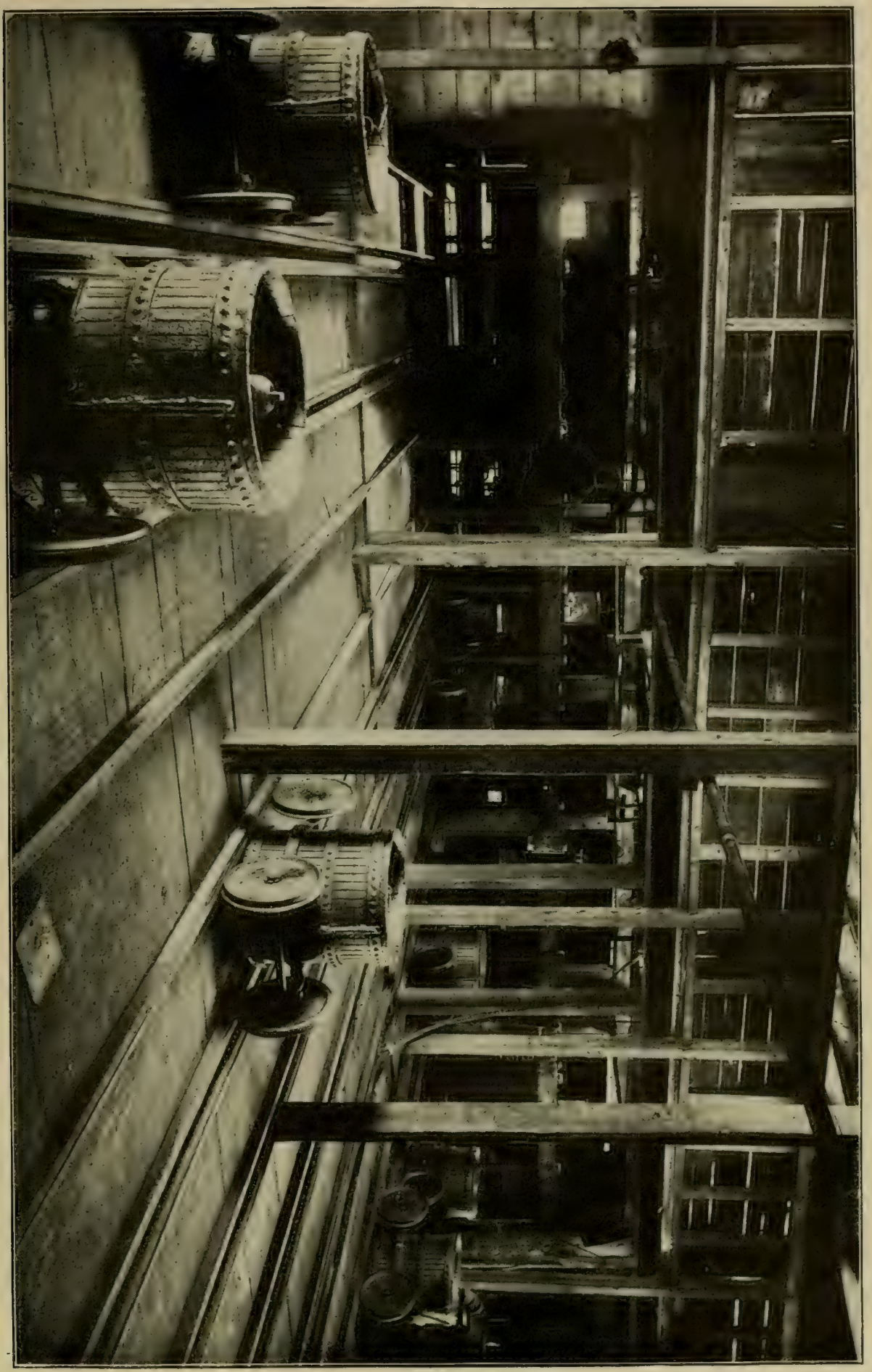



The yield of oil varies greatly, ranging from less than 7 pint 10 as much as 15 gallons or more per thousanel fish, or rather for rateh 22,000$)$ cubic inches of fish. As a rule, it is much greater in the antumu than in the spring, and also greater in Northern than in southern localities. Eren in the same locality the fish are very much fatter throughout some years than in others. For instance, the arerage yiele of the fish taken in Chesapeake Bay in 1887 was nearly (i pallons to the thousand, whereas in 1888 it was a little over 2 gallons, and early in that season it was less than 1 pint to the thousand fish. Some years ago one of the Shelter Island factories secured from one lot of fish a yield of 24 gallons to the thousand. The largest yield brought to the notice of the writer was deriver from some menhaden that had been inclosed in Shinnecock Bay late in autumm. By feeding in the brackish water of that bay these became so fat that they yielded at the rate of 48 gallons of oil per thousand fish. Considering the entire Atlantic coast for a series of ten year's ending in 1898 , it is found that each thousand fish yielded 4.59 gallons of oil and 138 pounds of scrap eontaining 10 per cent of moisture. During the ten years ending in 1888 the yield per thousand fish was $t$ gallons, and cluring the six years ending in 1878 it was 5.26 gallons.

The table given on page 233 shows the total yield of menhaden oil on the Atlantic coast of the United States and the arerage yield per thousand fish for each year since 1873 . From those figures it appears that the largest yield per thousand fish was $6.8 \pm$ gallons in $187 t$. The yield in 1887 and also that in 1886 were large, being 6.81 and 6.38 gallons, respectively. The smallest yield per 1,000 fish was in 18s0, 2.62 gallons, and in 1881, 2.79 gallons.

Not only does the yield of oil rary from year to year, but it also differs greatly in different sections of the comntry. As a rule, the Northern fish, or rather those taken in Northern waters, especially off the Maine coast, are the fattest, while those from off the southern coast yield the smallest quantity. In the year 1900 , for instance, the yicld of oil at the Rhorle Island factories was 5.76 gallons per 1,000 fish; in New York it was 6.39 gallons; in Delaware 4.92 gallons, and in Texas 3.51 gallons to the 1,000 fish. The menhaden taken off the coast of Maine are by far the fattest, and in the few seasons when fish are obtainable there the menhaden fishermen from other States hasten to - that eoast. In 1888 the Maine fish yielded 11.85 gallons of oil per 1,000; in 1889, 10.83 gallons, and in 1898, 9.73 gallons to the thousand measure. Menhaden have not been taken to any extent on that coast since 1898.

TREATMENT OF THE SCRAP.

As it leaves the press, fish scrap contains 45 or 50 per cent of water, which can not be removed by compression owing to the gelatinous condition of the fiber. Although suitable for immediate application as a fertilizer, the moist condition of this serap renders it unde- 
sirable for economic transportation or for storage for a great length of time, and necessitates further treatment. Previous to 1875 most of the scrap was sold in a green state, just as it came from the press, but since 1878 practically all of it has been dried or treated with sulphuric acid.

Formerly in drying it was customary at all the factories to spreat the green serap upon platforms, where it was exposed to the action of the sun for several days. While this is the common mothor at present, most of the large factories havo discarted it and are using artifieial driers. 'T'he platforms are male of tight or' matehed hoards laid flat upon a stout framework or upon the level ground, and are sometimes of large area, covering 2 or 3 acres. The scralp is transferred from the bin beneath the presses by means of screw conveyors and carried to a receiving bin, where it is dumped into hand carts with eapacity of one-half ton each and carried to the platform. It is there spread to a depth of from 3 to 6 inches and is frequently turned or raked over, so as to expose all particles to the sun's influence. In threatening weather and when the night dews are heavy, the scrap is raked into windrows or heaps and, if necessary, covered with canvas to protect it from moisture. After two or three day's' drying it is piled in heaps and left to sweat for a time, and then is again spreal to evaporate the free moisture generated in the heaps. This second drying reduces the amount of moisture in the scrap to about 10 per cent, and the material may be safely bagged and stored for market, though that operation is usually deferred until immediately before its shipment. Frequently the dried scrap is ground, especially when it is to be sold direct to the farmers without further treatment, in order that it may be sown in drills with wheat and other grains.

If good weather could always be depended on, platform-drying would possibly be the most economical and satisfactory method; but owing to uncertainties of the weather much diffeulty is frequently experienced in this process, resulting in a great waste of material and extra expenditure of labor and loss of ammonia in the scrap. 'This has resulted in the adoption of artificial driers at the largest factories. Several forms of apparatus have been employed, but the principle in most of them is similar, the serap being subjected to a current of heated air by meaus of a blower. The drier aclopted in the largest factories consists of an iron cylinder about 30 feet long and 5 feet in diameter, so mounted as to revolve horizontally. On the interior surface are shelves or paddles which, as the cylinder revolves, lift the scrap fed in at one end and permit it to fall to the bottom. A strong current of heated air is forced through the cylinder, extracting the moisture and gradually driving the scray out at the further end.

Another form of drier in use consists of a large double cylinder of iron set on an incline, into which the scrap is fed through an opening at the higher end and guided along to the lower end by means of a revolving screw. The space between the inner aud outer walls of 
the eylinder is filled with steam, which heats the serap, therehy evaporating most of the moisture.

Labor-saving devices make the handling of the scrap almost antomatic. From the presses it is transferred to the drier by means of screw conveyors and bucket elevators, and is fed intermittently in quantities of 200 pounds at intervals of 45 to 60 seconds. The capacity of a drier is $2 \frac{1}{2} 10: 3$ tons per hour, and the largest fatetories usually have 2 drying machines. From these the serap is conveyed to the storage room.

Although the term "dried" is popularly applied to all scrap from which a large portion of the moisture has been removed by evaporation, its use in a technical sense refer's to scrap containing not to exceed 12 per cent of moisture. In modern factories, green scrap fresh from the presises contains from th to 50 per cent of water. When desiccated so that ouly 10 per cent of its weight is water, each ton of chum or green serap yields about 1,156 pounds of "dried scrap." It is not always that so large a quantity of water is eliminated, and sometimes the finished scrap contains 25 and even 35 per cent of moisture. Owing to its tendency to lose nitrogen in the form of ammonia and its unsuitability for storage or transportation, the serap containing a high percentage of moisture is for use principally in the vicinity of the factories.

Not all the scrap, however, is dried, a large percentage being treated with sulphuric acid for the purpose of "fixing" the ammonia, preventing fermentation, and dissolving the bones. To every ton of serap, from 80 to 200 pounds of sulphuric acid of about $50^{\circ}$ strength is added and thoroughly commingled, the quantity of acid used depending to some extent on the state of the weather and the extent of decomposition of the fish. This is conveniently done by depositing the green scrap in handearts of 1,000 pounds capacity, whecling: these to an elevated platform and dumping the contents beneath, when the heap is immediately sprinkled with about 6f) pounds of sulphuric acid contained in a leaden pot. After a short while the bones dissolve and the mass becomes homogeneous and of a rich brown color, instead of the former grayish color. The ammonia is fixed by the acid and the tendency to decomposition overeome. The scrap is then conveyed to the storage room and shipped in bulk as recuired.

Instead of sulphuric acid, the solid granular sodium sulphate has been used to mix with the scrap, about 90 pounds being thoroughly combined with each ton. While this method is somewhat cheaper than applying sulphuric acid, it is not so satisfactory, and sodium sulphate is now little used for this purpose.

Owing to the difficulty in drying the scrap, most of that prepared at the Northern factories is acidulated, while the builk of the Southern product is dried. In the last year for which data are available, the product of the entire coast was 48,853 tons acidulated and $: 36,977$ 
toms dried, with a total selling value of $\$ 1,539,810$. () the 45,711 tons

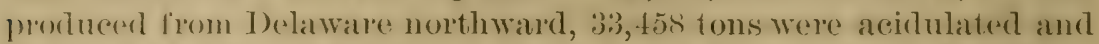
12,253 were dried, the average price of the former being s12.s7 per ton and the latter $\$ 26.22$ per ton. Sonth of Delaware the product of grem and of acidulated scratp combinorl, accolrling to the latest relurns, was 15,395 tons, while $2 t, 72 t$ tons were dricd, the resperetive values per ton being $\$ 12.95$ and $\$ 23.79$.

()nly a small percentage of the fish scrap is used by the farmers in the condition in which it laves the factories; most of it is glouml and serves ats an ingredient in compound or so-called "complete" fertilizers. Compound fertilizers are prepared at some of the menhaden factories, but as a general thing their preparation is in the hauds of persons who have nothing to do with eatching and rendering the fish.

The value of commereial fertilizers is dependent mainly on their content of nitrogin and phosphoric acid, which are the most important plant foods usually lacking in the soil. The nitrogen necesiary is supplier mainly by fish serap. Various other materials are also used, as dried blood, meat scrap) and other slaughter-house refuse, cotton seed, sulphate of ammonia, nitrate of sola, Peruvian guano, ete. The phosphoric acid is supplied by fish scrap to some extent, hut. principally by the phosphate rocks, boneblack from the sugat refineries, bone meal, ete., the solubility of the phosphate being increased by treatment with sulphuric acid, thus making superphosphates. The value of fish serap varies according to the pereentage of ammonia and phosphoric acid contained therein. As a general rule, dried serap) contains about \& per cent of nitrogen and str per cent of phosphoric acid. On a selling basis of $\$ 2 \pm$ per ton, the nitrogen costs ahout 10 cents per pound and the phosphoric acid about $33_{2}^{1}$ cents per pound for componnting purposes. Other necessary plant foods are potash, lime, magnesia, sulphuric acid, and iron. These usually exist in suffroient quantities in the soil itself, but are adter under special conditions, especially the potash. The nature of the ingredients and the respective proportions required vary according to the soil and the crop for which the compound is intended.

Although the agricultural value of dried fish serap is nearly equal to that of Peruvian guano, the market price is much below that article. In explanation of this fact it may be stated that fish serap is not, in such (ompact and good mechanical condition for shipment and general use. Its value as a fertilizing agent has not been so widely known as that of Peruvian guano, and thus its principal use is largely limited to the manufacturers of superphosphates, who are forced by eompetition to exercise great caution in the cost of manufacture. And, furthermore, there is a tendency to reduce the quantity of ammonia and increase that of phosphoric acid and potash in complete fertilizers in meet the repuirements of the soil. Other ammoniated materials now compete with fish guano in the making of superphosphates, among 


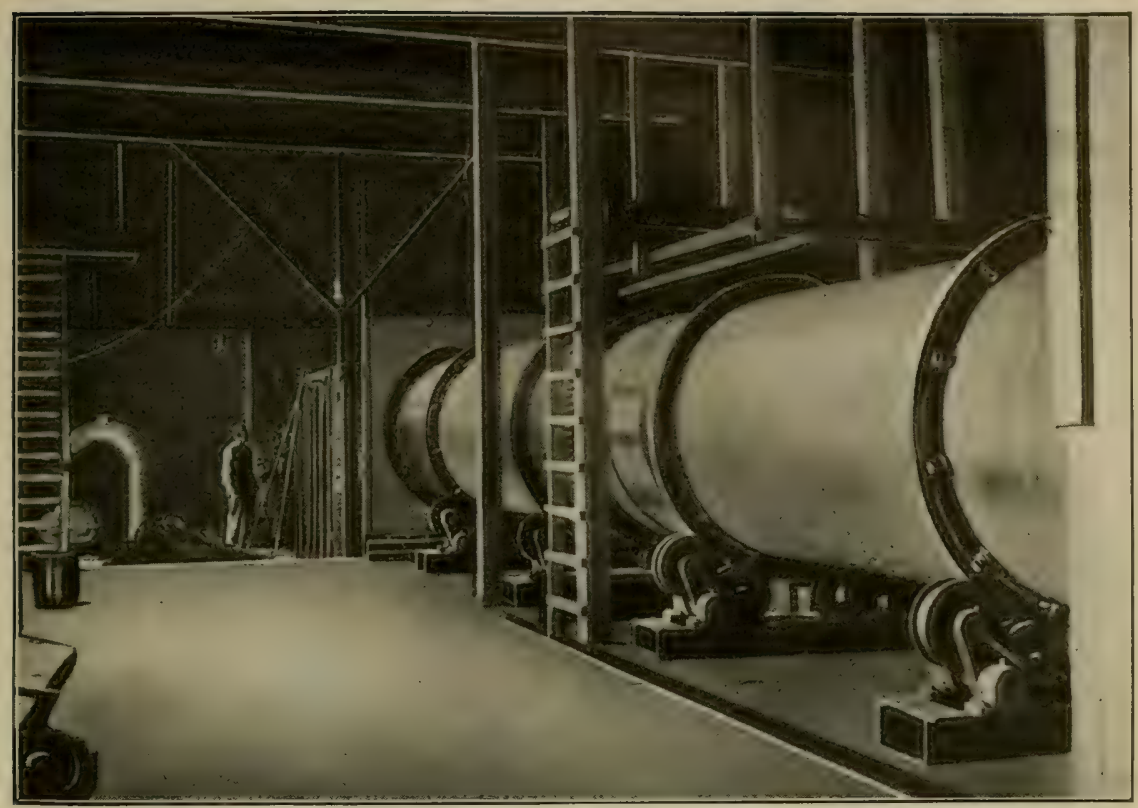

ARTIFICIAL DRIER IN FACTORY OF FISHERIES COMPANY, PROMISED LAND, NEW YORK. (SEE P. 266.)

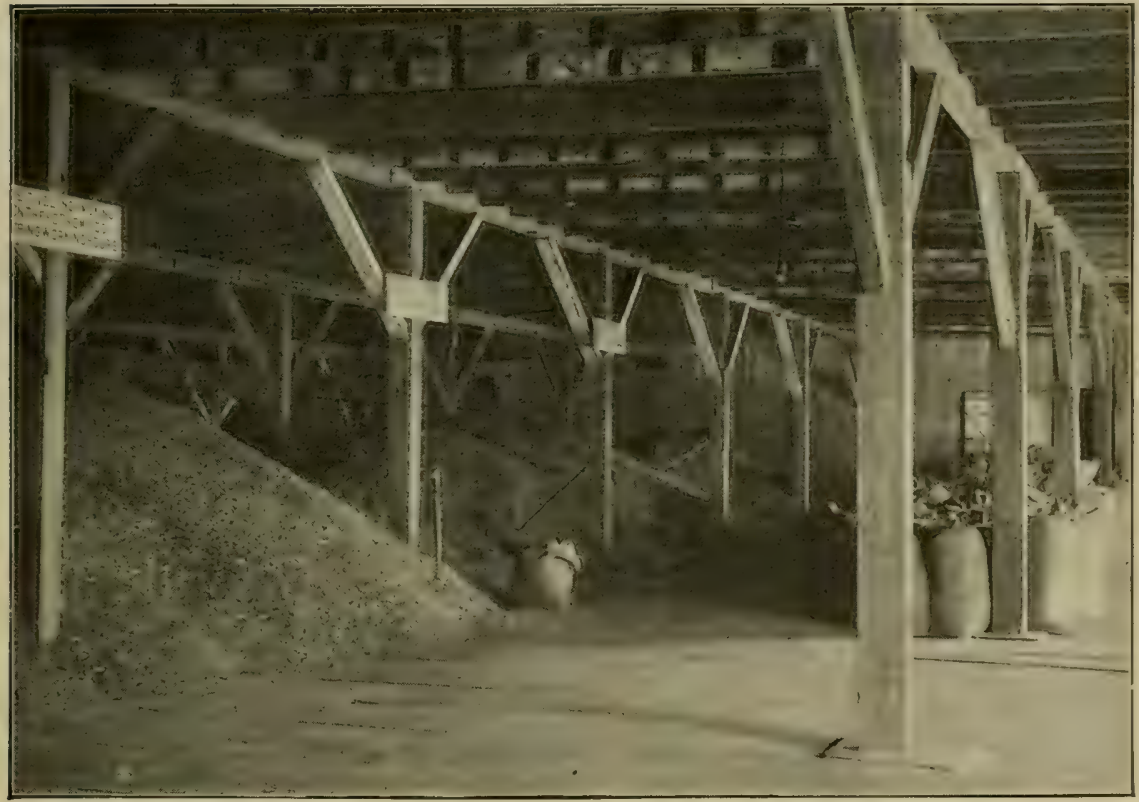

FERTILIZER ROOM IN FACTORY OF THE FISHERIES COMPANY, PROMISED LAND, N. Y. 

which are cotton seed, sulphate of ammonia, nitrate of sorla, timkirgo, meat scraps, slaughter-house refuse, etc.

The product of fish serap, reduced to basis of dried weight, produced

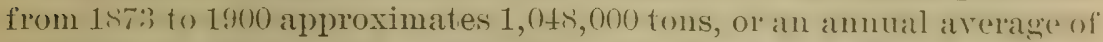
$37, \pm 28$ tons. As it is estimated that in a ton of compoum fertilizer leady for the soil the usual proportion of fish serap is 25 per cent, it is secu that the industry has contributed the ammoniate for $t, 1,12$, (H) tons of fertilizer, or at the rate of 149,712 tous ammully. In growing cot(on, for which these fertilizers are largely used, 250 pounds are generally. employed to raise one bale.

\section{FERTILIZERS FROM FISH WASTE OR REFUSE.}

Even in the food-fisheries large quantities of materials are obtained which ran not he used for food. This includes not only non-edible species, hut, also those eclible varieties which are not marketable, owing to such musual conditions as lack of transportation facilities or a glut in the market. It likewise includes the refuse in dressing fish for the markets and for canning, drying, salting, etc.

Formerly, when the markets were overstocked during warm weathere, large quantities of fresh fish spoiled and were suitable only for fertilizer. Even so choice a variety as the mackerel has been user for enriching land when taken in larger quantities than could be used for food purposes. In 1880, for instance, when the total catch of mackerel in New England approximated 132,000,000 pounds, 500,000 pounds of small fish were reported as having been used in Massachusetts as fertilizer:a

Previous to 1970 , according to Capt. N. B. Church, many thousand barrels of scup and sea bass, taken in trap nets between Cape Cod and Montauk Point, were purchased by the farmer's and spread on the land. Mr. A. B. Alexander states that large quantities of sharl taken in the Columbia River are used for fertilizer. With the development of fish freezers and the improved means of communication and transportation this waste is much reduced. Yet the aggregate quantity of foor-fish received in bad condition, or which "goes bad" in the markets, in the course of the year is very large in any populous city. During 18!y, according to the Fish Tracles Gazette, the quantity of fish condemuer by the officers of the Fishmongers' Company in Loncton was 1,526) tons, of which 232 tons were plaice, $2: 8$ tous Norwegian herring, 169) tons haddock, 94 tons mussels, 80 tons skate, 70 tons wellis, and (1) tous of periwiukles. In New Tork City the quantity of spoiled fish condemned during the summer amounts to several humbled thousand pounds each year. ${ }^{b}$

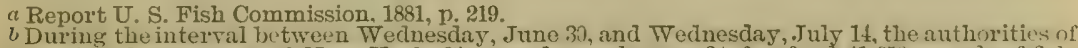
tho health department of New York City condemned as unfit for food 41 , (65) pounds of fish. of this amount. 39,650 pounds were seized in the Fulton Fish Market, the remainine : being condemned by the local inspectors among tho retail dealers in virious sections of the city. (The Fishing Gazette, 1902, p. 458.)
} 
Before the development of the sartine inclustry in Maine, the smatl fish taken in connection with the smoked-herring husiness were comlmonly converted into oil and fertilizer. After the oil had been cxtracted by boiling and pressing, the chum was broken up, sprearl on a board platform, and dried by the action of the sun. It was then ground, bagged, and sold at $\$ 12$ to $\$ 16$ per ton.

About fifteen years ago a factory was established at Pillar Point, on the shore of Lake Ontario, for converting the surplus alewires oceurring in that lake into fertilizer. The fish, obtained by means of seines and pound nets, were cooked for about 20 minutes in steam chests, permitted to drain for an hour, and then subjected to pressure in circular curbs holding about 5 barrels of chum each. The scrap was dried and ground and sold to the farmers for alout $\$ 20$ to $\$ 25$ per ton. It is reported that in $18861,000,000$ fish were utilized, yieldiug 500 gallons of oil and 63 tons of fertilizer. Along the shores of the Great Lakes and other waters, quantities of dead fish have been washed up in windrows, furnishing a harvest for the farmers in the vicinity.

In the pound-net fisheries of Cape Cod many skates and other "poor" fish, taken incidentally with the food-fish, are converted into fertilizer. If these contain much oil, it may be extracted by boiling and pressing. Ordinarily, however, the fish are dried without previous treatment. Especially is this the case with skates, which in some instances are suspended in rows above the ground until thoroughly dry, and are then ground fine. A large quantity of these fish hanging from a series of flakes or rails presents a very curious sight.

The quantity of waste and spoiled fish, howerer', is small compared with the very large amount of viscera and other offal resulting from dressing fish. The decrease in weight in dressing rauges from 15 to 35 per cent of the round weight, according to the species of fish and the season of the year. Assuming an average decrease of 25 per cent, it appears that in dressing the $900,000,000$ pounds of food-fish produced in the United Stater each year the refuse amounts to $225,0(10,000$ pounds, or 112,500 tous. While this is a rery large amount in the aggregate, it is so widely distributed that the quantity at any one place is not of great importance, and ustually its disposal is a sanitary problem rather than a source of revenue. In dressing fish at sea the waste is almost invariably thrown overboarct. In the cities this material is usually combined with and handled in the same way as other market refuse. At the canneries where large quantities of fish are chessed, as in the salmon canneries of the Pacific coast, and the sartine canneries of Maine, the refuse is now in many cases rendered into oil and fertilizer. 'This has already been noted in the chapter on the preparation of oils from waste products in the fisheries. (See pp. 240-242).

In case the fish dressings contain little oil the inducements for utilizing them are not great. Water constitutes a very large proportion of the viseera, the quantity ranging from 65 to 90 per cent, 

aceording to the species and the season. Even when the moisture is largely removed the quantity of fertilizing substances in the dried material is small. IIowever, if the quantity of oil in the waste is sufficient to pay the cost of its extraction, it is usually profitable to perform the slight additional labor necessary to make the material suitable for fertilizer. The manurial content of fish heads is relatively large, and whenever they are accumulated in large quantities their conversion into fertilizer is profitable.

$\Lambda$ convenient process of converting a small quantity of refuse from dressing fish into fertilizer is to store it in a receptacle made in the ground. This should be about 5 or 6 feet deep, with the area depending on the amount of refuse, but usually about 6 feet square. It should be dry and if the soil is sandy some clay should be spread at the bottom. First is placed a layer of wood ashes a few inches deep and then an equal layer of fish refuse eovered by a sprinkling of lime. Then follow another layer of ashes, one of fish refuse sprinkled with lime, and so on until the hole is full. It should be covered with earth or sod and these eoverer with weighted boards and permitted to so remain for several months. The fish refuse quickly disintegrates and becomes mixed with tho ashes, forming an excellent fertilizer.

Since 1875 the skins and bones resulting from the preparation of boneless codfish have been used for fertilizing purposes. After desalting them and extracting the glue, the remaining material is dried and sold for $\$ 15$ or $\$ 20$ per ton. The annual product amounts to about :3,0(00 tons. Most of this is produced at Gloucester, Mass., with smaller 'quantities at Boston, Provincetown, Portland, and Vinal Ilaren. According to analyses, this fertilizer contains about 10 or 12 per cent of phosphoric aeid, 8 or 9 per cent of nitrogen, and 5 or 6 per cent of moisture.

The refuse in preparing oil from livers of cod, sharks, and related species, from heads of halibut, sturgeon, and sword-fish, and from other materials is also dried and sold for fertilizer. The liver scrap formerly sold at $\$ 8$ or $\$ 10$ per ton, but at present its market value is only about half of that amount. Fertilizer made from fish heads is especially rich in phosphoric acid. A sample of guano made in Boston from fresh cod heads showed 20 per cent of phosphoric acid, $6 \frac{1}{2}$ per cent of nitrogen, aud $3 \frac{1}{2}$ per cent of moisture, and a sample of that made from fresh halibut heads contained 13 per cent of phosphoric acid, $5 \frac{1}{3}$ per cent of nitrogen, and 5 per cent of moisture.

An important fish fertilizer in Norway is made from the refuse in Aressing cod for drying, consisting principally of heads and backbones. These are merely dried by spreading them on the rocks and are then broken and ground to the condition of coarse bone-meal. In some localities the refuse is first steamed, to facilitate the drying and grinding. The utilization of these materials for fertilizer was begun about 1855, and the industry is centered at the Loforlen Islands, the location of the primcipal cod fishery of Europe. The present 
annual production is said to be upward of 10,000 tons of prepared scrap, about $20,000,000$ cod heads being utilized for the purpose.

According to a report made by Consul-General Crowe, of the British service, the heads and bones are first partly dried in the open air anrl then cut into small pieces and thoroughly dried in a kiln. Then all but 12 or 15 per cent of moisture has been driven off, the materials are crisher and then ground between millstones to the fineness of cor'n meal. The heads and bones are crushed separately, but are mixed together before the grinding process, the usual proportion of the mixture being one part of the baekbones to five parts of the heads. Chemical analyses indicate an average content of water 1:3 per cent; organic substances 49.3 per cent, of which 8 per cent is nitrogen and 7.6 per cent ammonia; and inorganic substances 37.7 per cent, of which 14.9 per cent is phosphoric acid.

In utilizing whales at the Norwegian stations established in connection with the taking of these cetaceans, the flesh and bones are commonly prepared as fertilizer after the extraction of the oil. The blubher and the fat-lean are first removed from the flesh for oil-rendering, and then the flesh is eut into strips or minced in a machine and boiled with steam under pressure. As describerl by Michael Winnem, in Chemische Revue, the receptacles for boiling the flesh are horizontal iron eylinders provided with close-fitting openings. They are also provided with two outlet pipes, one at the very bottom, for removing the water, and the other about $t$ inches higher up, for drawing' off the oil. The flesh is spread on three superimposed perforated trays or false bottoms, and subjected within the cylinder to steam at a pressure of 40 or 50 pounds to the square inch for ten or twelve hours. At the end of that period the flesh is removed and placed in drying ovens. These are built of brick, 20 to 25 feet high, and fitted with internal sheet-metal trays, which are monuted alternately on the sides of the oven and on a central revolving shaft. The latter carries a number of slanting serapers which revolve once in 5 minutes and slowly force the flesh from one tray to the next lower ones in succession. The descending flesh is dried by the heated air from a colse fire, which enters the oven at the top and passes out through an opening at the bottom.

The process is somewhat slow, the output during twenty-four hours not exceeding 2 tons for each oven. If desired, the fertilizer may be ground in a mill. The bones are broken and treated in much the same mamner as the flesh. After boiling they are crushed in a disintegrator, ground in a bone-mill, and mixed with the flesh scrap. An analysis, made by Krocker, of Norwegian whale fertilizer indicated 7.63 per cent of nitrogen, 13.45 per cent of phosphoric acid, 16.49 per cent of lime, and 0.15 per cent of magnesia in a sample containing 5.35 per cent of moisture. The market price is about $£ 5$ per ton. In the bottle-nose fishery the oil is commonly extracted at sea, as in case of the American whale fishery, and consequently it is not practicable to utilize the flesh and bones as fertilizer. 


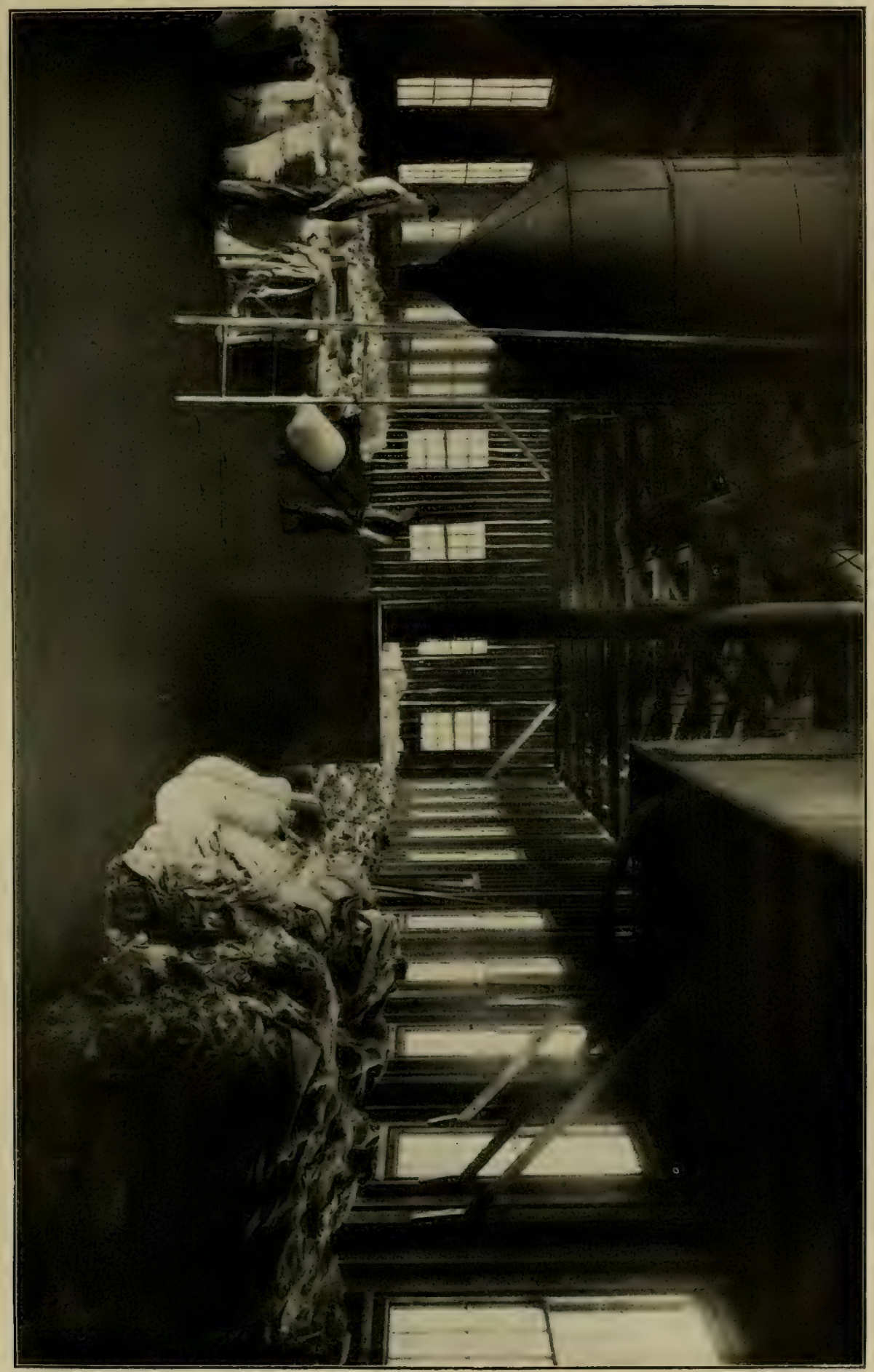





\section{FERTILIZERS FROM CRUSTACEANS.}

Among the nost curious of the marine products used for fertilizer is the horseshoe crab (Limulus polyphemus), which is found in comparative abundance at several points on the Atlantic coast and especially on the shores of Delaware Bay. The use of this fertilizer clates loack at least a hundred years, old records indicating its employment by the farmers of Cape Cod in the eighteenth century. It is reported that they were first used in the Delaware Bay region about fifty years ago. In that section they are taken during May and June, when large numbers visit the shallow waters for spawning purposes. During the remainder of the year they are scarce inshore, although a few may be obtained. They are secured by picking them up at night on the shore either by hand or with pitchforks, or they are taken in pound nets constructed especially for that purpose. The pound nets cost $\$ 25$ to $\$ 75$ each, and they secure by far the greater number. At present the catch is very much less than it was twenty years ago. In 1880, according to the returns of the United States Fish Commission, the total catch in Delaware Bay amounted to $4,300,000$ in number, worth $\$ 16,300$. In 1890 , it was only $1,939,670$, worth $\$ 8,580$, and in 1897 it was still further reduced to $1,206,095$, worth $\$ 8,393$. The value of the horseshoe crabs ranges from $\$ \pm$ to $\$ 8$ per thousand and the weight averages about 2 pounds each.

In preparing them for fertilizer, the entire crabs are sometimes merely stacked in piles until they putrefy and become somewhat dry, when they are broken into fragments and composted with muck, lime, or other suitable materials. Two or three small factories exist at which the crabs are dried and ground, or they are ground while green and then mixed with sodium sulphate or sulphuric acid. The product sells for $\$ 15$ to $\$ 25$ per ton, and is an excellent fertilizer for grain and fruits. The output in 1880 approximated 1,950 tons, in 1890 it was reduced to 880 tons, and in 1901 it was still further reduced to 500 tons.

When lobsters were canned on the coast of Maine, a desirable grade of fertilizer was made from the shells and other refuse of the canneries. This refuse was sold at a nominal price at the factories, or given away for the hauling. The farmer's collecting it would usually dry and grind it and then spread it on the land. Letters patent were issued to William D. IIall, in 1865, for the preparation of this fertilizer, but his rights in the matter were never protected. This waste is thus utilized at the present time at the lobster canneries in Nova Scotia and New Brunswick.

The shells of shrimp produced in the fisheries of California and Louisiana are used to a considerable extent for fertilizer, which is employed by the Chinese not only on the Pacific seaboard but also in the Orient. The shells are removed from the dried shrimp and sold 
at alout. s5 per ton. In C'alifornia they are especially valued in strawherry and vegetable culturo, while in China their principal use is as fertilizer for rice, tea plants, ete. In strawberry culture, from 300 to tou pounds are commonly applied to caleh acre. It has also been used in wheat-growing, being spread broadeast on the land after tho first plowing.

\section{A.GRICULTURAL LIME FROM MOLLUSK SHELLS.}

'The shells of oyster's, clams, mussels, etc., have long been valued for agricultural purposes. All along the Atlantic coast of the United States, the extinct oyster beds, the old shell heaps, and even the living oyster reefs have long heen resorted to by the neighboring farmers as a storehouse for top-dressing for their fields. In the Gulf states the most luxuriant vegetation along the shore is upon the shell mounds and marl deposits. Most of the material, however, is obtained from the shucking establishments where mollusks are opened in large quantities. Previous to the discovery of the limestone resources of Pemnylvania and other States, large quantities of shells were burned for lime; but at present their use for this purpose is confined largely to localities where the shells are unusually abundant and cheap.

An article in the Country Gentleman, volume 7, page 155, refer's to the use of mussel shells for manure with especial reference to Essex County, Mass., as follows:

Thousands of cords of mussel shells are annually taken from the beds of the streams bordering on the sea and used on cultivated ground. I have repeatedly witnessed the value of this fertilizer in the growing of carrots and onions. The very best crop of carrots I saw the last season, more than 34 tons to the acre, had no other fertilizer applied to the land. For the last thirty years I have known it applied to lands on which onions have been grown, with a product varying from 300 to 600 bushels to the acre. It sells, delivered several miles from where it is dug, at $\$ t$ to $\$$, the cord. It is usually gathered in the winter months, taken to the shore in scows or gondolas, and thence to the fields where it is used. Sornetimes it is laid in a pile of several cords together, and after it has been exposed to the frosts of winter, distributed from $t$ to 8 corcts to the acre. At other times it is lail out in heaps of a few bushels only, which remain for a time exposed to the frost.

According to Storer, "lime is not a fertilizer in itself, but is of indirect value on laud in unlocking the available potash, phosphorus, and nitrogen in the soil." It also renders heavy, compact soils looser in texture and tends to bind particles of loose, leachy soils.

It is difficult to approximate the sum total of value which shells confer on agriculture, owing to the extensive use of marl deposits. Of refuse shells from shucking-houses and the like, the quantity used in this country is doubtless uprat of 60,000 tons annually.

The prepared lime is generally preferred to the ground shells. Analyses indicate that the organic matter contained in shells is wellnigh free from nitrogen, and there is no evidence that it is of any use as manure. It appears, therefore, that there is no need for the expense of grinding the shells and of carting the useless constituents 
which can be expelled by burning. Since grinding does not reduce the material to so fine a state as burning does, the ground shell is not so active chemically.

The most popular manner of utilizing shells is to burn them and slack the product with water. The slacking may be done in heaps covered with moistened earth, and the fine powdery hydrate of lime spread directly upon the land; or the lime may be used in the compost heap; or the quicklime may be left to become air-slacked by exposure to the air, and the product be applied to the land instead of leached ashes.

\section{AQUATIC PLANTS AS FERTILIZERS.}

Although it does not appear that the many properties of aquatic plants have been fully exploited, their uses are far more numerous and dirersified than is generally supposed. Their most widely known economic value is as furnishing thousands of tons of fertilizer and a great variety of nutritious and wholesome foods. In addition thereto, they are utilizer in the production of many ehemicals, especially iodine and bromine, and as a constituent in glues and gelatines, and as a basis for trade fruit-jellies. They also serve in sizing fabrics, in refining beer, as a mordant in dyeing, as composition in cement for covering boilers; for stuffing upholstery, packing porcelain, in making paper, fishing-lines, ropes, buttons, handles for cutlery, as tents in surgical operations, ete. The gathering of seaweeds in Great Britain early in the present century is said to have given employment to about 100,000 persons, the product being used in the manufacture of carbonate of soda.

On the coasts of France and the British Isles thousands of tons of seaweeds are collected amnually for fertilizing the crops. In China and Japan they have been used as fertilizer for many centuries, but in recent years the employment of seaweeds for this purpose has been much reduced, owing to their more extended use as food and in the chemical and maunfacturing industries. In the New England states they are probably the most important fertilizing material used on those farms immediately adjoining the sea. According to Storer, with the exception of the farms of the Connecticut Valley and those enriched by fish scrap or by manures received from the cities, "the only really fertile tracts in New England are to be found back of those sea beaches upon which an abundant supply of seaweeds is thrown up by storms." In the Middle Atlantic States the use of seaweeds as fertilizer is not so extensive, but in the aggregate very large quantities are employed. Elsewhere in the United States their use is of less importance.

There are three principal groups of aquatic plants used in this country for fertilizer, riz, rockweeds, kelp, and eelgrass or grass rack. Rockweeds are the large dark-colored plants furnished with small bladder's or snappers, which constitute at least 75 per cent of the 
covermg of bolis and stomes between high and low water markis on the coatst from Noval seotia to New Tork. There alre two prominent species of these, the round-stalled and the flat-stalked. The principal species of lielp, viz, the riblon-weed and the broad ribhon-weed or devil's anron, are common on the rocks at and below the low-water mark from Newfomeland to the New Jersey coast. In the north of Europe both of these species are user for food to a eomsirlerable extent. Dulse, Irish moss, and other species may also be used for fertilizer, but the quantity obtained is so small that they are of litile importance in this connection.

The principal fertilizing agencies in aquatic plants are nitrogen and potash; the quantity of phosphoric acid is very small, amounting to only aloout 10 per cent as much as the above two combined. Seaweculs also contain considerable quantities of lime and magnesia. By the adclition of somo material containing a large percentage of phosphoric acid, as bone meal, for instance, a."complete fertilizer" is formed. This is frefuently very important in order to secure the full value of the nitrogen and potash contained in the seaweeds.

According to analyses made by the Rhode Island Agricultural Experiment station, ${ }^{a}$ the average percentage of fertilizing constitnents and of water contained in various aquatic plants in the fresh state collected at different seasons on the coast of Rhorle Island is as follows. For convenience of comparison, analysis of average barnyard manure is appended.

\begin{tabular}{|c|c|c|c|c|}
\hline Materials. & Nitrogen. & $\begin{array}{c}\text { Phosphoric } \\
\text { acid. }\end{array}$ & Potash. & Water. \\
\hline $\begin{array}{l}\text { Rockweed, flat-stalked } \\
\text { Rockweed, round-stalked } \\
\text { Broad ribbon-weed, or deril's apron. } \\
\text { Ribbon-weed, kelp, or tangle } \\
\text { Dulse } \\
\text { Irish moss } \\
\text { Eelgrass } \\
\text { Barnyard manure }\end{array}$ & $\begin{array}{l}\text { Per cent. } \\
.38 \\
.24 \\
.23 \\
.17 \\
.37 \\
.57 \\
.35 \\
.49\end{array}$ & $\begin{array}{c}\text { Per cent } \\
.12 \\
.08 \\
.06 \\
.05 \\
.09 \\
.13 \\
.07 \\
.32\end{array}$ & $\begin{array}{l}\text { Per cent. } \\
.65 \\
.64 \\
.31 \\
.16 \\
1.07 \\
1.0 \% \\
.32 \\
.43\end{array}$ & $\begin{array}{l}\text { Percent. } \\
76.55 \\
77.26 \\
87.50 \\
87.99 \\
86.25 \\
76.03 \\
81.19\end{array}$ \\
\hline
\end{tabular}

The total quantity of the fertilizing ingredients in plants is very small in proportion to the weight of the material, this being due principally to the large content of water. Usually at least 75 per cent of the weight of aquatic plants consists of water, and about 80 per cent of the remainder is a soft, easily decomposable form of organic matter. The plants decompose rapidly, and the water separates from them quickly, the weeds left in heaps on the beach being reduced to onehalf or one-third of their original bulk in a few weeks. Since much of the fertilizing constituents, especially the nitrogen, wastes away in this process, it is important that the plants be used within as short a time as practicalble after they have been collected. For the same reason it is much better to collect weeds directly from the rocks, or 
those just thrown up by a storm, rather than those which have lain on the beach for a considerable time.

The large content of potash makes sea plants, particularly rockweeds, especially favorable to the growth of clover. Storer refers to the abunclant natural growth of red clover upon the tract of eountry back of Rye Beach, Maine, which has been manured with these plants since the settlement of the country. Seaweeds are also excellent for wheat, and are used for parsnips, turnips, and to some extent for potatoes, although it is claimed that they impart a somewhat unpleasant flavor to the last-named. The general opinion in this country is that potatoes grown with seaweeds are much less liable to be affected by seab than those grown with barnyard manure, but they are less mealy and of inferior flavor." Seaweeds have been strongly recommenderl for tobacco-culture, but owing to their effect on the quality of the leaf, they are not much used for this purpose. They are also highly recommended for cauliflower and cabbages. They act very quickly, and the effect of their application is confined largely to the season in which they are used, having little action upon the second and succeeding crops.

Owing to their small content of fertilizing materials and the large amount of moisture, aquatic plants are usually rather expensive for fertilizer if long cartage is required, at least 4 tons of water being transported for every ton of dry material. This limits their value to the immediate vieinity of the beaches, and they are rarely used on land more than 10 or 12 miles from the coast.

Ifowever, the manurial value of seaweeds must not be regarded merely from the point of view of the fertilizing agencies which they contain. They have a mechanical action on the soil, tending' to make it friable and binding its constituents together; but the manufacture of soil is rather expensive where there is so much good laud available as in this country. They have an advantage over barnyard manure in the freedom from seeds of land weeds. Formerly it was considered desirable to apply the material in the form of a compost with lime or gypsum, but experience of recent years indicates that it does not pay as a rule to compost them, except possibly in case of eelgrass and also rockweeds, to be applied as a summer or autumn top-dressing for grass land. ${ }^{b}$ The usual practice in applying them is to plow the seaweeds into the soil or to spread them upon the land as a fop-tressing, the plants being in either case in as fresh a state as practicalble. They also tend to prevent the crops from suffering from summer droughts, grass fields dressed with seaweeds frequently remaining green when adjacent fields àre suffering.

So important is the crop of seaweeds in the Channel Islands that special laws are enforced to govern their collection and distribution. The eutting of weeds from the rocks is restricted to certain seasons comprising about four or five weeks each year. Those cast up on the 
shores by the action of the waves are collected throughont the year and especially during stormy weather, furnishing employment to a large proportion of the inhabitants of Guernsey and Jersey. They are anplied to the land not only in a green state, as in this country, but are also burned on the beach and on the cottage hearths and the ashes used as fertilizer.

Large quantities of seaweeds are also burned on the coast of France, especially in Brittany and Normandy, and on the coasts of Ireland and scotland. In this process the plants are usually treated for the obtainment of iodine and salts of potassium and sodium, leaving the potash salts as the prineipal fertilizing agent. Although greatly reduced, owing to the production of iodine from South American caliche, the quantity of iodine made from the ashes of seaweeds is yet very large. The ashes of seaweeds are not used as fertilizer to any great extent, if at all, in this country, owing to the fact that, in burning, the valuable nitrogen is driven off and lost. IIowever, for use at a greater distance than 12 or 15 miles from the coast it might be found practicable to burn them if this ean be clone with a small expenditure.

Several unsuccessful attempts have been marle in this country to establish a profitable business in preparing commercial fertilizer from seaweeds. About thirty years ago a factory was built for this purpose at Boothbay, Me. Dried seaweeds were ground in a mill formed of 40 circular saws, 20 having teeth and 20 without. These were placed alternately on an iron shaft and so adjusted as to revolve in a concave trough fitted with 40 steel plates. The shaft weighet 1,000 pounds and made upward of 2,000 revolutions per minute. With this apparatus 3 tons per hour of the thoroughly dried seaweeds could be reduced to about the fineness of oats. There proved to be an insufficient market for the fertilizer, and its manufacture was discontinued in a few years. ${ }^{a}$ Most of it was sold in Commecticut for the use of tobacco-growers. The average price at the factory for the prepared material was about $\$ 8$ per ton.

Notwithstanding its relatively large content of nitrogen, phosphoric acirl, and potash, as revealed by chemical analysis, extgrass is of rery little value as a fertilizer, owing to the difficulty in making those constituents available. According to Storer's well-known work on fertilizers (pp. 167-168, vol. 2):

Eelgrass taken by itself has little or no fertilizing power. It will har 11 y rot anywhere, either in the ground, in the hogsty, or in the manure or compost heap. It is a distinctly inconvenient thing, moreover, to have in the way of the plowshare or the dungfork. It has long stood as a kind of reproach among the regetable manures, much as leather scraps stand in the list of animal products. For mulching for covering bins or piles of roots as protection against frost, moldiness, and decay, and for banking up in autumn around stables, greenhonses, cisterns, cellars, and pumps, eelgrass has been found useful, and this is about all 
that could have been said in its favor until very recently. Considered as a manure, it was rejected by the farmers long ago. It has been tried and found wanting by numerous generations of men. Still, on analysis it appears that eelgrass contains a considerable proportion of fertilizing matters, and there can be no doubt that it will be found amenable to proper treatment and will eventually be prized as a manure. Besides $1 \frac{1}{3}$ per cent of nitrogen, air-dried eelgrass contains 1 per cent of potash and 0.25 per cent of phosphoric acid. The ashes of eelgrass contain 7 per cent of potash and $1 \frac{1}{2}$ per cent of phosphoric acid, which is about as much as is contained in ordinary house ashes from wood fires. The trouble with eelgrass is, as was said before, that it will not rot in the soil. It must be coerced in some way in order to make its fertilizing constituents available for crops. It might be burned, for example, to ashes in order to get the potash and phosphoric acid; or, much better, the organic matter may be disorganized by composting the grass with lime or with rockweed. That is to say, the eelgrass may either be thrown into heaps, with layers of lime interpolated, in order to reduce the resisting tissue to a manageable form, or it may be built into a heap, layer by layer, with fresh rockweed or sea manure, and so subjected to destructive fermentation.

It is quite impracticable to form a close estimate of the total quantity of aquatic plants used for fertilizer in this country. The latest returns of the United States Fish Commission show an output on the New England coast of 75,000 tons, worth about $\$ 1$ per ton, but these figures probably do not show the total production. According to the Rhode Island census of $1885, \$ 65,044$ worth of seaweeds were used in that State alone during the census year, compared with a total of $\$ 164,133$ worth of "commercial" fertilizers. This represents only a small percentage of the total quantity obtainable, it being possible to collect a thousand or more tons to the mile of that coast. The growth of the plants is rapid, and rocks scraped bare may be covered with kelp 5 or 6 feet long the following year. 


\section{LIBRARY OF CONGRESS}

MAR E 1908

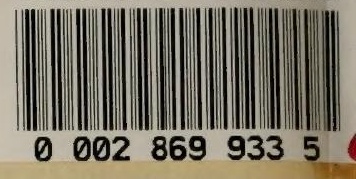

b 0028699335 
$y^{2}+x^{2}-x^{2}=3$

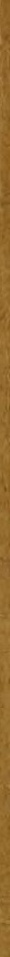




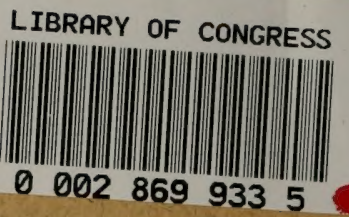

